Cochrane Database of Systematic Reviews

\title{
Interventions for preventing oral candidiasis for patients with cancer receiving treatment (Review)
}

Clarkson JE, Worthington HV, Eden TOB

Clarkson JE, Worthington HV, Eden TOB.

Interventions for preventing oral candidiasis for patients with cancer receiving treatment.

Cochrane Database of Systematic Reviews 2007, Issue 1. Art. No.: CD003807.

DOI: 10.1002/14651858.CD003807.pub3.

www.cochranelibrary.com

Interventions for preventing oral candidiasis for patients with cancer receiving treatment (Review) Copyright $\odot 2019$ The Cochrane Collaboration. Published by John Wiley \& Sons, Ltd. 
TABLE OF CONTENTS

HEADER

ABSTRACT

PLAIN LANGUAGE SUMMARY

BACKGROUND

OBJECTIVES

METHODS

RESULTS

DISCUSSION

AUTHORS' CONCLUSIONS

ACKNOWLEDGEMENTS

REFERENCES

CHARACTERISTICS OF STUDIES

DATA AND ANALYSES

Analysis 1.1. Comparison 1 Comparisons with placebo/no treatment for all drug types, Outcome 1 Oral candidiasis present. ..

Analysis 1.2. Comparison 1 Comparisons with placebo/no treatment for all drug types, Outcome 2 Systemic fungal infection. .

Analysis 1.3. Comparison 1 Comparisons with placebo/no treatment for all drug types, Outcome 3 Death.

Analysis 1.4. Comparison 1 Comparisons with placebo/no treatment for all drug types, Outcome 4 Empirical antifungal treatment.

Analysis 1.5. Comparison 1 Comparisons with placebo/no treatment for all drug types, Outcome 5 Toxicity (adverse events 'probably due to drug').

Analysis 1.6. Comparison 1 Comparisons with placebo/no treatment for all drug types, Outcome 6 Good compliance. ............

Analysis 2.1. Comparison 2 Comparisons between drugs absorbed from GI tract and those not absorbed, Outcome 1 Oral candidiasis present.

Analysis 2.2. Comparison 2 Comparisons between drugs absorbed from GI tract and those not absorbed, Outcome 2 Systemic fungal infection.

Analysis 2.3. Comparison 2 Comparisons between drugs absorbed from GI tract and those not absorbed, Outcome 3 Death. ... Analysis 2.4. Comparison 2 Comparisons between drugs absorbed from $\mathrm{GI}$ tract and those not absorbed, Outcome 4 Empirical antifungal treatment.

Analysis 2.5. Comparison 2 Comparisons between drugs absorbed from GI tract and those not absorbed, Outcome 5 Toxicity (adverse events 'probably due to drug').

Analysis 2.6. Comparison 2 Comparisons between drugs absorbed from GI tract and those not absorbed, Outcome 6 Good compliance.

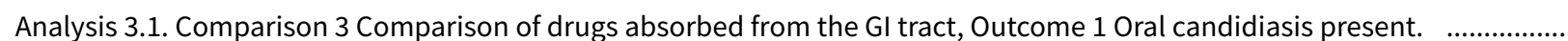

Analysis 3.2. Comparison 3 Comparison of drugs absorbed from the GI tract, Outcome 2 Systemic fungal infection. ................

Analysis 3.3. Comparison 3 Comparison of drugs absorbed from the $\mathrm{Gl}$ tract, Outcome 3 Death. ............................................

Analysis 3.4. Comparison 3 Comparison of drugs absorbed from the GI tract, Outcome 4 Empirical antifungal treatment. .......

Analysis 3.5. Comparison 3 Comparison of drugs absorbed from the GI tract, Outcome 5 Toxicity (adverse events 'probably due to drug').

Analysis 3.6. Comparison 3 Comparison of drugs absorbed from the GI tract, Outcome 6 Good compliance.

Analysis 4.1. Comparison 4 Comparison of drugs not absorbed from GI tract, Outcome 1 Oral candidiasis present.

Analysis 5.1. Comparison 5 Comparisons with placebo/no treatment for not absorbed drug types, Outcome 1 Oral candidiasis present.

ADDITIONAL TABLES

APPENDICES

WHAT'S NEW

HISTORY

CONTRIBUTIONS OF AUTHORS

DECLARATIONS OF INTEREST

SOURCES OF SUPPORT

NOTES

INDEX TERMS

2

3

3

3

5

8 
[Intervention Review]

\section{Interventions for preventing oral candidiasis for patients with cancer receiving treatment}

Janet E Clarkson'1, Helen V Worthington², Tim OB Eden 3

1Division of Oral Health Sciences, Dundee Dental School, University of Dundee, Dundee, UK. 2Cochrane Oral Health, Division of Dentistry, School of Medical Sciences, Faculty of Biology, Medicine and Health, The University of Manchester, Manchester, UK. ${ }^{3}$ Young Oncology Unit, Christie Hospital NHS Trust, Manchester, UK

Contact address: Janet E Clarkson, Division of Oral Health Sciences, Dundee Dental School, University of Dundee, Park Place, Dundee, Scotland, DD14HR, UK. j.e.clarkson@dundee.ac.uk.

Editorial group: Cochrane Oral Health Group

Publication status and date: Stable (no update expected for reasons given in 'What's new'), published in Issue 9, 2019.

Citation: Clarkson JE, Worthington HV, Eden TOB. Interventions for preventing oral candidiasis for patients with cancer receiving treatment. Cochrane Database of Systematic Reviews 2007, Issue 1. Art. No.: CD003807. DOI: 10.1002/14651858.CD003807.pub3.

Copyright ( 2019 The Cochrane Collaboration. Published by John Wiley \& Sons, Ltd.

\section{A B S T R A C T}

\section{Background}

Treatment of cancer is increasingly more effective but is associated with short and long term side effects. Oral side effects remain a major source of illness despite the use of a variety of agents to prevent and treat them. One of these side effects is oral candidiasis.

\section{Objectives}

To assess the effectiveness of interventions (which may include placebo or no treatment) for the prevention of oral candidiasis for patients with cancer receiving chemotherapy or radiotherapy or both.

\section{Search methods}

Computerised searches of Cochrane Oral Health Group and PaPaS Trials Registers, CENTRAL, MEDLINE, EMBASE, CINAHL, CANCERLIT, SIGLE and LILACS were undertaken.

Reference lists from relevant articles were searched and the authors of eligible trials were contacted to identify trials and obtain additional information.

Date of the most recent searches: 3 August 2009: CENTRAL (The Cochrane Library 2009, Issue 3).

\section{Selection criteria}

Trials were selected if they met the following criteria: design - random allocation of participants; participants - anyone receiving chemotherapy or radiotherapy treatment for cancer; interventions - agents prescribed to prevent oral candidiasis; primary outcome prevention of oral candidiasis.

\section{Data collection and analysis}

Data were recorded on the following secondary outcomes if present: relief of pain, amount of analgesia, relief of dysphagia, incidence of systemic infection, duration of stay in hospital (days), cost of oral care, patient quality of life, death, use of empirical antifungal treatment, toxicity and compliance.

Information regarding methods, participants, interventions, outcome measures and results were independently extracted, in duplicate, by two review authors. The Cochrane Collaboration statistical guidelines were followed and risk ratios (RR) calculated using random-effects models. Potential sources of heterogeneity were examined in random-effects metaregression analyses. 


\section{Main results}

Twenty-eight trials involving 4226 patients satisfied the inclusion criteria. Drugs absorbed and partially absorbed from the gastrointestinal (GI) tract were found to prevent oral candidiasis when compared to a placebo, or a no treatment control group, with RR for absorbed drugs $=0.47$ (95\% confidence interval $(\mathrm{Cl}) 0.29$ to 0.78 ). For absorbed drugs in populations with an incidence of $20 \%$ (mid range of results in control groups), this implies a number needed to treat (NNT) of 9 ( $95 \% \mathrm{Cl} 7$ to 13) patients need to be treated to avoid one patient getting oral candidiasis. There was no significant benefit shown for drugs not absorbed from the GI tract.

\section{Authors' conclusions}

There is strong evidence, from randomised controlled trials, that drugs absorbed or partially absorbed from the GI tract prevent oral candidiasis in patients receiving treatment for cancer. There is also evidence that these drugs are significantly better at preventing oral candidiasis than drugs not absorbed from the GI tract.

\section{PLAIN LANGUAGE SUMMARY}

\section{Interventions for preventing oral candidiasis for patients with cancer receiving treatment}

There is strong evidence that some antifungal drugs prevent oral candidiasis (thrush) caused by cancer treatment, but nystatin does not appear to work.

Treatment for cancer can lead to severe fungal infections (thrush) in the mouth. This can cause discomfort, pain, difficulties in eating, longer stays in hospital and more worryingly, systemic infection and risk to life. Different drugs are used to try and prevent this condition. The review found strong evidence from a large number of trials that some of the antifungal drugs (those absorbed and partially absorbed into the body) help prevent fungal infections in the mouth. Some other commonly used drugs such as nystatin, which are not absorbed into the body, do not appear to work. 


\section{B A C K G R O U N D}

Treatment of solid malignant tumours and the leukaemias with cytotoxic chemotherapy or radiotherapy or both is becoming increasingly more effective but it is associated with short and long term side effects. Among the clinically important acute side effects is the disruption in the function and integrity of the mouth. The consequences of this include severe ulceration (mucositis) and fungal infection of the mouth (oral candidiasis). These disease and treatment induced complications may also produce oral discomfort and pain, poor nutrition, delays in drug administration, increased hospital stays and costs and in some patients life threatening infection (septicaemia). These potential problems have prompted clinicians to use agents during cancer treatment to prevent such oral complications.

Antifungal agents are often used during the treatment of cancer to prevent superficial infections including oral candidiasis. Prevention of superficial infection is considered important because of its possible role in the development of systemic fungal infection. The incidence of systemic fungal infection has increased with the development of increasingly effective cancer therapy causing greater mucosal damage and prolonged neutropenia (De Pauw 1997). Systemic infection is difficult to diagnose early and consequently cure because it rapidly becomes well advanced and disseminated leading to considerable morbidity and mortality. Sometimes empirical antifungal treatment is given to patients without documented fungal infection but with persistent fever despite antibiotic treatment. A current Cochrane review concludes that the only prophylactic or empirical antifungal agent with documented evidence of reducing mortality in cancer patients with neutropenia is intravenous amphotericin B (Gotzsche 2002). In this review studies concerned with the prevention and treatment of oral candidiasis were excluded.

We consider it important to review the evidence for the prevention of oral candidiasis because of the effect a fungal infection in the mouth has on general well being and the possible related systemic consequences. This review is one in a series of four Cochrane reviews evaluating the evidence for the prevention and treatment of oral candidiasis and oral mucositis in patients treated for cancer (Clarkson 2007; Worthington 2007; Worthington 2007a).

\section{O B J E C T IVES}

To assess the effectiveness of interventions (which may include placebo or no treatment) for the prevention of oral candidiasis for patients with cancer, receiving chemotherapy or radiotherapy or both.

The following primary null hypothesis was tested for comparisons between groups receiving interventions to prevent oral candidiasis during cancer treatment:

There is no difference in the proportion of patients acquiring oral candidiasis during cancer treatment.

In this review we proposed to address the hypothesis of no difference between groups treated for oral candidiasis for the following outcomes if data were available.

- Relief of pain (binary: yes/no)

- Amount of analgesia (continuous)

- Relief of dysphagia (binary: yes/no)
- Incidence of systemic infection (binary: yes/no)

- Duration of stay in hospital (days) (continuous)

- Cost of oral care (continuous)

- Patient quality of life (continuous or binary)

- Death (binary: yes/no)

- Use of empirical antifungal treatment (binary: yes/no)

- Toxicity (adverse events 'probably due to drug') (binary: yes/no)

- Compliance (binary: good versus other).

The following subgroup analyses were proposed.

- Cancer type (leukaemia, solid cancer and mixed)

- Age group (adults, children or both).

\section{METHODS}

\section{Criteria for considering studies for this review Types of studies}

Only randomised controlled trials (RCTs) were eligible for inclusion in this review.

\section{Types of participants}

Anyone with cancer who received chemotherapy or radiotherapy or both.

\section{Types of interventions}

Active agents: any antifungal intervention for the prevention of oral candidiasis.

Control: may be placebo or no treatment, or another active intervention.

\section{Types of outcome measures}

The following outcome was considered in this review.

- Oral candidiasis (binary: absent or present).

The following secondary outcomes were recorded if present.

- Relief of pain (binary: yes/no)

- Amount of analgesia (continuous)

- Relief of dysphagia (binary: yes/no)

- Incidence of systemic infection (binary: yes/no)

- Duration of stay in hospital (days) (continuous)

- Cost of oral care (continuous)

- Patient quality of life (continuous or binary)

- Death (binary: yes/no)

- Use of empirical antifungal treatment (binary: yes/no)

- Toxicity (adverse events 'probably due to drug') (binary: yes/no)

- Compliance (binary: good versus other).

\section{Search methods for identification of studies}

This review is part of a series of four reviews on the prevention and treatment of oral candidiasis and oral mucositis in patients with cancer, and the same search strategies were used for all four reviews. 
The searches attempted to identify all relevant trials irrespective of language. Papers not in English were translated by members of The Cochrane Collaboration.

Electronic searching - the databases searched were:

Cochrane Oral Health Group Trials Register

Cochrane Pain, Palliative and Supportive Care (PaPaS) Group Trials

Register

Cochrane Central Register of Controlled Trials (CENTRAL) (The

Cochrane Library 2009, Issue 3)

MEDLINE (from 1966) and MEDLINE Pre-indexed

EMBASE (from 1974)

CINAHL

CANCERLIT via PubMed

OPEN SIGLE

LILACS.

Sensitive search strategies were developed for each database using a combination of free text and MeSH terms. These are described in detail in Appendix 1; Appendix 2; Appendix 3; Appendix 4; Appendix 5; Appendix 6; Appendix 7 and Appendix 8.

Only handsearching carried out by The Cochrane Collaboration is included in the search (see master list www.cochrane.org).

The controlled trials database (www.controlled-trials.com) was also searched to identify ongoing and completed trials and to contact trialists for further information about these trials.

The reference list of related review articles and all articles obtained were checked for further trials. Authors of trial reports and specialists in the field known to the review authors were written to concerning further published and unpublished trials.

The review will be updated every 2 years using the Cochrane Oral Health Group Trials Register, CENTRAL, MEDLINE, EMBASE, CINAHL, CANCERLIT, SIGLE, and LILACS.

Date of most recent searches: 03.08.09 (CENTRAL) (The Cochrane Library 2009, Issue 3), MEDLINE 03.08.09, EMBASE 03.08.09, CINHAL 03.08.09, LILACS 03.08.09, CANCER LIT 03.08.09, OHG Register 03.08.09, Papas Register 29.07.09.

\section{Data collection and analysis}

The titles and abstracts (when available) of all reports identified through the searches were scanned independently by two review authors (Jan Clarkson (JC) and Helen Worthington (HW)). Full reports were obtained for trials appearing to meet the inclusion criteria, or for which there was insufficient information in the title and abstract to make a clear decision. The full reports obtained from all the electronic and other methods of searching were assessed independently, in duplicate, by two review authors to establish whether the trials met the inclusion criteria or not. Disagreements were resolved by discussion.

\section{Quality assessment}

The quality assessment of the included trials was undertaken independently and in duplicate by two review authors as part of the data extraction process.

Three main quality criteria were examined.

(1) Allocation concealment, recorded as:

(A) Adequate
(B) Unclear

(C) Inadequate as described in the Cochrane Handbook for Systematic Reviews of Interventions 4.2.5.

(2) Treatment blinded to outcome assessors, patients and providers recorded as:

(A) Yes

(B) No

(C) Unclear

(D) Not possible.

(3) Completeness of follow up (is there a clear explanation for withdrawals and drop outs in each treatment group?) assessed as: (A) Yes

(C) No.

After taking into account the additional information provided by the authors of the trials, studies were grouped into the following categories based on three criteria: allocation concealment, treatment blinded to outcome assessor and completeness of follow up:

(A) Low risk of bias (plausible bias unlikely to seriously alter the results) if all criteria were met.

(B) Moderate risk of bias (plausible bias that raises some doubt about the results) if one of the criteria was not met.

(C) High risk of bias (plausible bias that seriously weakens confidence in the results) if two or more criteria were not met as described in the Cochrane Handbook for Systematic Reviews of Interventions 4.2 .5 section 6.7 .

Further quality assessment was carried out to assess sample size calculations, definition of exclusion/inclusion criteria, and comparability of control and test groups at entry. The quality assessment criteria were pilot tested using several articles.

The quality assessment of included trials was undertaken independently and in duplicate by two review authors as part of the data extraction process. Included trials were assessed on the following criteria: concealed allocation of treatment; blinding of patients, carers and outcome assessors; and information on reasons for withdrawal by trial group. The risk of bias was assessed as high, moderate or low, according to the Cochrane Handbook for Systematic Reviews of Interventions 4.2.5. The agreement between the review authors was assessed by calculating the Kappa score.

Data were extracted by two review authors independently using specially designed data extraction forms. The characteristics of the trial participants, interventions and outcomes for the included trials are presented in the study tables. The incidence of oral candidiasis was measured in several different ways ranging from clinical examination to mycological assessment. The clinical assessment was used if present otherwise the mycological assessment was included. Oral candidiasis was recorded as absent or present, and the 'Characteristics of included studies' table includes a description of the methods of measurement used. The duration of trials was recorded along with interim assessments and a decision made about which to use to maximise commonality. We also recorded the country where the trial was conducted, which year it was published and whether a dentist was involved in the investigation. Authors were contacted for clarification or for further information. 
We decided a priori to categorise the interventions as whether they were fully absorbed, partially absorbed or not absorbed from the gastrointestinal (GI) tract.

\section{Data synthesis}

For dichotomous outcomes, the estimates of effect of an intervention was expressed as risk ratios together with 95\% confidence intervals. Where there were studies of similar comparisons reporting the same candidiasis outcome measure a meta-analysis was undertaken. Risk ratios were combined for the dichotomous data, and mean differences combined for continuous data, both using a random-effects model.

The significance of any discrepancies in the estimates of the treatment effects from the different trials was assessed by means of Cochran's test for heterogeneity, and the $1^{2}$ statistic, where $1^{2}$ describes the percentage of total variation across studies that is due to heterogeneity rather than chance. Any heterogeneity was fully investigated.

\section{Investigation of publication and other biases}

A funnel plot (plots of effect estimates versus the inverse of their standard errors) was drawn. Asymmetry of the funnel plot may indicate publication bias and other biases related to sample size, though it may also represent a true relationship between trial size and effect size. A formal investigation of the degree of asymmetry was performed using the method proposed by Egger et al (Egger 1997). A further method proposed by Begg and Mazumdar which tests for publication bias by determining if there is a significant correlation between the effect estimates and their variances was also carried out (Begg 1994). Both methods were carried out using Stata version 7.0 (Stata Corporation, USA) using the program Metabias.

It was planned to undertake a sensitivity analysis to examine the effect of concealed allocation, blinded outcome assessment and assessment of study as of low risk of bias on the overall estimates of effect. We also proposed a priori to conduct subgroup analyses for different cancer types (solid, leukaemia and mixed) and age groups (children, adults and mixed). These analyses were undertaken using random-effects metaregression, using the Stata version 7.0 (Stata Corporation, USA) using the program Metareg (Sharp 1998).

\section{RE S U L T S}

\section{Description of studies}

\section{Characteristics of the trial setting and investigators}

of the 112 potentially eligible trials, 82 studies were excluded for the following reasons:

- no oral outcome or data in the wrong form (34 trials);

- the data were presented as episodes not patients (10 trials);

- used as empirical therapy only treating patients with infection (nine trials);

- abstracts with insufficient information (five trials);

- not a randomised controlled trial or this was unclear (17 studies);

- liver transplant patients (one trial);

- inappropriate study design (five trials);
- study halted early (one trial).

Of the 28 included trials, nine were conducted in North America (Bodey 1990; Buchanan 1985; Cuttner 1986; Epstein 1992; Ferretti 1988; Owens 1984; Vogler 1987; Winston 1993; Yeo 1985), 16 in Europe (Brincker 1978; Brincker 1983; Caselli 1990; Egger 1995; Giorgis 1991; Hann 1982; Huijgens 1999; Menichetti 1994; Menichetti 1999; Ninane 1994; Orlandi 1986; Palmblad 1992; Philpott-Howard 1993; Rozenberg-Arska 1991; Wahlin 1989; Williams 1977), and a further three, one in South Africa (Scrimgeour 1985), one in Brazil (Nucci 2000) and one in Japan (Yamada 1993). All trials had a parallel group study design. The trials were published in 34 reports between 1977 and 2000 with two trials published in the 1970s, 13 in the 1980s, 18 in the 1990s, and one trial since 2000. Five were multicentre studies (Menichetti 1994; Menichetti 1999; Ninane 1994; Philpott-Howard 1993; Winston 1993) and six studies had more than one publication. Eighteen of the trials received external funding, three trials did not and this was unclear in the remaining seven. The percentage of patients lost to follow up ranged from $0 \%$ to $81 \%$, with a median value of $5 \%$. Eight studies reported no drop outs and this included two large multicentre studies (Brincker 1983; Buchanan 1985; Caselli 1990; Cuttner 1986; Menichetti 1994; Menichetti 1999; Wahlin 1989; Williams 1977). The providers and assessors of the treatments were mainly medical staff though three of the trials clearly involved a dentist (Epstein 1992; Ferretti 1988; Wahlin 1989) but in no trial were patients involved in the outcome measurement. Two further studies are awaiting classification (Corvo 2008; Elad 2006).

\section{Characteristics of the participants}

Seventeen of the 28 trials recruited only adult patients with cancer, eight included both adults and children, two included only child patients (Caselli 1990; Ninane 1994) and in one trial the age of the patients was unclear (Scrimgeour 1985). The type of cancer being treated was leukaemia in 18 trials, solid tumours in three trials and a combination of both in seven trials.

\section{Characteristics of the interventions}

All of the 28 trials provided a clear description of the interventions including the dose and method of administration for both the test and control group. Eleven trials included a placebo control group, a further six a 'no treatment' control group, and one trial had a group using a saline rinse (Epstein 1992). Eight trials compared different test agents with varying doses, frequency and duration of use. One trial compared different doses of the same test agent (Scrimgeour 1985).

The interventions for the 28 trials assessing the treatment of oral candidiasis were categorised according to the degree of absorption from the gastrointestinal (GI) tract.

\section{Absorbed from the GI tract}

- Fluconazole (Bodey 1990; Egger 1995; Huijgens 1999; Menichetti 1994; Ninane 1994; Philpott-Howard 1993; Rozenberg-Arska 1991; Winston 1993)

- Ketoconazole (Brincker 1983; Caselli 1990; Hann 1982; Palmblad 1992; Scrimgeour 1985; Vogler 1987)

- Itraconazole (Caselli 1990; Huijgens 1999; Menichetti 1999; Nucci 2000). 


\section{Partially absorbed from the GI tract}

- Miconazole (Brincker 1978)

- Clotrimazole (Cuttner 1986; Owens 1984; Yeo 1985).

\section{Not absorbed from the GI tract}

- Amphotericin B (Caselli 1990; Menichetti 1994; Orlandi 1986; Rozenberg-Arska 1991; Yamada 1993)

- Nystatin (Buchanan 1985; Egger 1995; Epstein 1992; Vogler 1987; Williams 1977)

- Chlorhexidine (Epstein 1992; Ferretti 1988; Wahlin 1989)

- Nystatin + chlorhexidine (Epstein 1992)

- Thymostimulin (Giorgis 1991)

- Amphotericin B + nystatin (Hann 1982)

- Polyenes (amphotericin B or nystatin) (Ninane 1994; PhilpottHoward 1993)

- Natamycin (Williams 1977)

- Norfloxacin + amphotericin B (Yamada 1993).

The trials assessing absorbed drugs are generally more recent $(1982$ to 2000 ) than those for either partially absorbed drugs (1978 to 1986) or those for drugs not absorbed (1977 to 1995).

\section{Characteristics of outcome measures}

There was variation between the trials in the assessment of oral candidiasis. Three trials just reported a clinical assessment of oral candidiasis (Brincker 1983; Williams 1977; Yamada 1993), six trials only a mycological assessment (Buchanan 1985; Caselli 1990; Cuttner 1986; Epstein 1992; Giorgis 1991; Winston 1993), and 19 trials presented both types of assessment frequently with the clinical assessment being confirmed by a mycological assessment. The percentage of patients developing candidiasis in the 19 control or no treatment groups ranged from $5 \%$ to $100 \%$, with a median value of $50 \%$.

Several other outcomes were recorded, by study group, in some of the trial reports. Systemic fungal infection was recorded in 17 studies (Brincker 1983; Caselli 1990; Egger 1995; Ferretti 1988; Hann 1982; Huijgens 1999; Menichetti 1994; Menichetti 1999; Ninane 1994; Nucci 2000; Owens 1984; Palmblad 1992; Philpott-Howard 1993; Rozenberg-Arska 1991; Vogler 1987; Winston 1993; Yamada 1993 ) and this ranged across study groups from $0 \%$ to $46 \%$. Death associated with fungal infection was recorded in eight trials $10 \%$ to 11\%) (Egger 1995; Ferretti 1988; Hann 1982; Huijgens 1999; Menichetti 1994; Menichetti 1999; Nucci 2000; Palmblad 1992), empirical antifungal treatment in eight trials (0\% to $74 \%$ ) (Egger 1995; Hann 1982; Huijgens 1999; Menichetti 1994; Nucci 2000; Owens 1984; Rozenberg-Arska 1991; Winston 1993), toxicity due to adverse events 'probably due to treatment' in 13 trials ( $0 \%$ to 18\%) (Cuttner 1986; Egger 1995; Huijgens 1999; Menichetti 1994; Menichetti 1999; Ninane 1994; Nucci 2000; Owens 1984; PhilpottHoward 1993; Rozenberg-Arska 1991; Scrimgeour 1985; Vogler 1987 ; Winston 1993) and good compliance in five trials (72\% to $99 \%)$ (Egger 1995; Huijgens 1999; Menichetti 1994; Menichetti 1999; Nucci 2000).

\section{Risk of bias in included studies}

The concealment of allocation was adequate for $13(46 \%)$ of the 28 trials but it was unclear for the remaining 15 (Additional Table 1). The outcome assessor was blinded in 16 trials (57\%), not blinded in four trials and masking was unclear in the remaining eight trials. The withdrawals were adequately reported in 18 trials (64\%) and were unclear or not reported in the remainder. The Kappa scores between the two raters were: 0.70 for allocation concealment, 0.39 for blinding of outcome assessor, 0.46 for clear information about withdrawals.

Letters were sent to authors of the trials and replies were received from the authors of 12 included and one excluded study, the information supplied changed the concealment of allocation from unclear to adequate in eight studies, and clarified the reasons for withdrawal, or missing data.

Five studies were assessed as at low risk of bias (Brincker 1978; Brincker 1983; Cuttner 1986; Nucci 2000; Wahlin 1989), 10 at moderate risk and 12 at high risk of bias (Additional Table 1 ).

\section{Effects of interventions}

Electronic searches identified over 6000 titles and abstracts and from this we obtained over 400 full reports for the four reviews in this series. One hundred and nine studies were considered eligible for this review according to the defined criteria for trial design, participants, interventions and outcomes. Of these 81 trials were excluded for reasons summarised in the Description of studies section.

For the 28 trials included in the review the results are based on 4226 patients who were assessed for oral candidiasis. The range of patients was from eight to 420 per treatment/control group.

\section{Comparisons with placebo/no treatment: oral candidiasis (comparison 1, outcome 1.1)}

Seven trials involving 1153 patients compared drugs absorbed from the gastrointestinal (GI) tract with placebo, or 'no treatment' control group and the meta-analysis showed that these drugs prevented oral candidiasis with risk ratio (RR) of $0.47(95 \%$ confidence interval $(\mathrm{Cl})_{\text {Random Effects }} 0.29$ to $0.78, \mathrm{Chi}^{2}=10.2$, degrees of freedom $\left.(d f)=6, P=0.12, I^{2}=41 \%\right)$. In order to illustrate the magnitude of the effect, the number of patients needed to treat (NNT) to prevent one patient getting oral candidiasis were calculated, based on this pooled effect estimate and on the incidence of oral candidiasis in the control groups of the trials that contributed data to this meta-analysis. The incidence was $5 \%$ to $60 \%$, median value $20 \%$. In populations with a low incidence of oral candidiasis of $5 \%$, this gives a NNT of $37(95 \% \mathrm{Cl} 29$ to 56) patients requiring treatment to avoid one patient getting oral candidiasis during the cancer treatment period. In populations with an incidence of $20 \%$ (mid range of results in control groups), this implies a NNT of $9(95 \% \mathrm{Cl} 7$ to 13$)$ patients requiring treatment to avoid one patient getting oral candidiasis. For populations with a high incidence $(60 \%)$ the NNT is $3(95 \% \mathrm{Cl} 3$ to 5$)$.

Four trials involving 292 patients compared drugs partially absorbed from the GI tract with placebo and these drugs were also found to prevent oral candidiasis $\left(\mathrm{RR}=0.13,95 \% \mathrm{Cl}_{\text {Random Effects }}\right.$ 0.06 to $\left.0.46, \mathrm{Chi}^{2}=5.3, \mathrm{df}=3, \mathrm{P}=0.15, \mathrm{I}^{2}=43 \%\right)$.

Eight studies involving 382 patients compared drugs not absorbed from the GI tract with placebo or no treatment control groups, and overall the drugs did not have a significant benefit in preventing oral candidiasis RR $=0.68\left(95 \% \mathrm{Cl} 0.46\right.$ to $1.02, \mathrm{Chi}^{2}$ for 
heterogeneity $=23.3, \mathrm{df}=7, \mathrm{P}<0.001, \mathrm{I}=70 \%$ ). Since $70 \%$ of the total variation across studies is due to heterogeneity rather than chance this was investigated. Subgroup analyses were conducted for age group and cancer type and these factors failed to explain the large heterogeneity present for the eight studies involving the nonabsorbed drugs, however, this was investigated further in a metaanalysis presented later in this section.

\section{Comparisons with placebo/no treatment: other outcomes (comparison 1, outcomes 1.2-1.6)}

Significantly more control patients were given empirical antifungal treatment than patients receiving drugs absorbed from the $\mathrm{Gl}$ tract, $\mathrm{RR}=0.85\left(95 \% \mathrm{Cl}_{\text {Random Effects }} 0.73\right.$ to $0.99, \mathrm{Chi}^{2}=$ 0.55 , df $=1, P=0.46,12=0 \%$ ) (outcome 1.4). There were no significant differences between patients receiving antifungal drugs in any category compared with placebo or 'no treatment' for the following outcomes: systemic fungal infection, death, toxicity and compliance (outcomes 1.2, 1.3, 1.5, 1.6).

\section{Comparisons between drugs absorbed from the GI tract and those not absorbed: oral candidiasis (comparison 2, outcome 2.1)}

Nine studies compared drugs absorbed from the GI tract directly with those not absorbed, although there were no participants with candidiasis in one trial, so the data from eight studies were included. The meta-analysis showed a significant benefit in using the absorbed drugs rather than those not absorbed to prevent oral candidiasis with $\mathrm{RR}=0.40\left(95 \% \mathrm{Cl}_{\text {Random Effects }} 0.21\right.$ to $0.76, \mathrm{Chi}^{2}$ for heterogeneity $=12.5, \mathrm{df}=6, \mathrm{P}=0.052, \mathrm{I}^{2}=51.9 \%$ ).

\section{Comparisons between drugs absorbed from the GI tract and} those not absorbed: other outcomes (comparison 2, outcomes 2.2-2.6)

There were no significant differences between patients receiving either absorbed or drugs not absorbed from the GI tract for the following outcomes: systemic fungal infection, death, empirical antifungal treatment, toxicity and compliance (outcomes 2.3, 2.4-2.6).

\section{Comparison of drugs absorbed from the GI tract: oral candidiasis (comparison 3, outcome 3.1)}

Three trials compared different drugs absorbed from the GI tract. One study compared itraconazole with fluconazole finding no evidence of a difference (Huijgens 1999). Another study compared ketoconazole with itraconazole also finding no difference (Caselli 1990). A further study compared two doses of ketoconazole $200 \mathrm{mg}$ and $400 \mathrm{mg}$ (Scrimgeour 1985), however as none of the patients experienced oral candidiasis the results of the study have no value.

\section{Comparison of drugs absorbed from the GI tract: other outcomes (comparison 3, outcomes 3.2-3.6)}

There were no significant differences for any of the other outcomes.

\section{Comparison of drugs not absorbed from the GI tract: oral candidiasis (comparison 4, outcome 4.1)}

Three trials compared different drugs which were not absorbed from the GI tract. One study compared three groups of patients using chlorhexidine, nystatin, and chlorhexidine plus nystatin (Epstein 1992). The two other studies compared nystatin with natamycin (Williams 1977), and norfloxacin plus amphotericin B with amphotericin B (Yamada 1993). There was no evidence of a difference between the drugs for the first two studies and a borderline effect for the norfloxacin study, with fewer patients in the norfloxacin group getting oral candidiasis $(P=0.05)$. Only one of these studies reported another outcome, systemic infection, which was not significant with RR $=0.67(95 \% \mathrm{Cl} 0.20$ to 2.23$)$ (Yamada 1993). No other outcomes (systemic fungal infection, death, empirical antifungal treatment, toxicity or compliance) were reported in these studies.

\section{Publication bias}

Publication bias was assessed for the primary outcome, oral candidiasis, for three groups of trials:

- drugs absorbed from $\mathrm{Gl}$ tract versus placebo (7 trials, comparison 1, outcome 1.1);

- drugs not absorbed from GI tract versus placebo (8 trials, comparison 1, outcome 1.1);

- absorbed drugs versus drugs not absorbed (7 trials, comparison 2, outcome 2.1).

The funnel plot for each appeared asymmetric and there is evidence of bias for all three groups of studies using the Egger (weighted regression) method $(P=0.003,<0.001,0.018$, respectively), but not using the Begg (rank correlation) method ( $P=0.65,0.30,0.22$ ) (Begg 1994; Egger 1997).

\section{Metaregression}

See Additional Table 2.

Metaregression models were fitted, using Stata version 7 , to investigate how much of the heterogeneity of treatment effect is explained by drug type (three categories), age group (three categories) and cancer type (three categories) for the 19 comparisons in 18 placebo controlled or no treatment control trials. A univariate analysis for drug type showed significant differences for both the absorbed $(P=0.016)$ and partially absorbed drugs $(P=0.002)$ when compared with the non-absorbed drugs, the drugs absorbed or partially absorbed from the Gl tract being more effective (Additional Table 2). It is recognised that there are weaknesses in using indirect comparisons, however, the indirect comparison for absorbed drugs did support the findings of the direct comparison (comparison 2, outcome 2.1). The model for age group (including drug type) showed no significant differences in the effect size for the different age groups however the model for cancer type (including drug type) showed a significant difference between cancer types, with the treatment effect being greater for trials including patients with blood $(P=0.032)$ and mixed cancers $(P=0.031)$ compared to those including patients with solid cancer. Further metaregression models were fitted for both allocation concealment and outcome assessment blinded (including drug type), and no significant difference in effect size was found between studies assessed as adequate or not for either of these quality assessments.

A sensitivity analysis was proposed for studies at low risk of bias. Five studies were categorised as this, but only one in each of the classes of drugs for the comparisons between drugs and placebo or no treatment. For absorbed drugs (Brincker 1983) the RR was 0.25 (95\% Cl 0.06 to 1.03$)$, for partially absorbed drugs (Cuttner 1986) the RR was 0.09 ( $95 \% \mathrm{Cl} 0.01$ to 0.65$)$ and for drugs not absorbed 
(Wahlin 1989) the RR was $0.89(95 \% \mathrm{Cl} 0.79$ to 1.02$)$ so the results were similar to those for all studies.

A priori we decided to categorise the drugs into three categories: absorbed, partially absorbed and not absorbed from the GI tract. When comparing drugs in each of these categories with placebo or 'no treatment' controls it was found that there was significant heterogeneity for the not absorbed category of drugs, whereas the other two categories were fairly homogeneous. In order to investigate this heterogeneity further, the eight comparisons involving not absorbed drugs can be categorised further into drug types: nystatin (two trials), amphotericin B (two trials), chlorhexidine (three trials) and thymostimulin (one trial). The comparisons between the groups were not significant in a metaregression analysis (nystatin versus amphotericin $\mathrm{B}, \mathrm{P}$ $=0.09$; nystatin versus chlorhexidine, $\mathrm{P}=0.41$; nystatin versus thymostimulin, $\mathrm{P}=0.18$ ). However classification by drug type did appear to reduce the heterogeneity, although there are only a few trials in each category. The meta-analysis shown in MetaView (comparison 5, outcome 5.1) indicates that there may be some benefit for amphotericin B with RR $=0.43(95 \% \mathrm{Cl} 0.20$ to 0.94$)$, whereas there is no evidence of a benefit for nystatin.

\section{DISCUSSION}

We have found evidence that antifungal agents absorbed from the gastrointestinal tract prevent oral candidiasis in patients receiving treatment for cancer. Drugs fully absorbed (fluconazole, ketoconazole and itraconazole) and partially absorbed (miconazole and clotrimazole) are effective compared with placebo or no treatment. The quality of the trials was mixed, however no differences in effect size were found when poor quality studies were excluded. There is no evidence that overall the group of non-absorbed drugs are effective and looking at these drugs individually this finding is consistent for the commonly prescribed oral polyene, nystatin, however, there is weak evidence that amphotericin B might be of benefit. Both direct and indirect comparisons demonstrate the superiority of absorbed compared with non-absorbed drugs to prevent superficial oral fungal infections. However, it is not possible to assess the importance in terms of effectiveness, of how long drugs are retained in the mouth, or the local or systemic concentrations.

No trial reported outcomes related to general well being such as relief of pain, relief of dysphagia, amount of analgesia, days stay in hospital and patient quality of life. It is therefore difficult to comment on the importance of these patient based outcomes although, they are frequently cited as justification for the conduct of trials. Neither is it possible to comment on the cost of oral care as no trial reported either specific or comparative data. It is not possible to assess the association between oral candidiasis and systemic infection from the data presented. However, from trials reporting systemic outcomes, the prophylactic use of absorbed drugs reduced the proportion of patients receiving empirical antifungal treatment compared with control patients (two trials).

For patients being treated for cancer the clinical dilemma is whether to prevent, treat or leave oral candidiasis. The findings from our reviews demonstrate that oral candidiasis can be effectively prevented, however the evidence for effective treatment is weaker and unreliable (Worthington 2007). Compared with this review, which includes evidence from over 4000 patients, the treatment review included trials on around 400 patients and only two agents were found to be effective (ketoconazole and clotrimazole) each in single trials. The decision to use antifungal agents to prevent or treat superficial oral infections requires consideration of the risks and benefits. In this review toxicity due to adverse events 'probably due to treatment' was documented in 13 trials of the 28 included trials and ranged from $0 \%$ to $18 \%$, however little information was given concerning the nature and severity of the toxicity. More careful documentation of this in future trials included in both reviews would help to evaluate the possible risks of these interventions.

The incidence of oral candidiasis is variable and depends primarily on the nature of the underlying disease and the intensity of treatment. The incidence in control groups included in this review ranges from $5 \%$ to $100 \%$, with a median value of $50 \%$. The generalizability of the results is difficult to comment on as the trials were mainly adults with blood cancer, with few studies including children, although the metaregression did indicate possible differences in effect with different cancer types. Since there is no evidence of an effect on general well being to support the decision to prevent oral candidiasis, and there is weak evidence that effective prophylaxis is associated with a reduction in systemic disease, other factors require consideration. If the incidence of oral candidiasis for a patient subgroup is likely to be high, and it is considered important to prevent the disease, then a drug absorbed or partially absorbed from the gastrointestinal tract should be prescribed at the start of cancer treatment. Factors for which we have little information and further evidence is required are: the implications of drug toxicity, development of microbial drug resistance and the cost of treatment.

Whilst most of the trials report similar criteria for the diagnosis of oral candidiasis the validity of these descriptions requires consideration and a consensus on how to diagnose and report events in future trials would improve the synthesis of evidence. Epidemiological data and more consistent microbiological reporting would assist our understanding of the importance of this disease. There is some evidence that there may be publication bias, with an under reporting of small trials showing no treatment effect. It is difficult to assess the impact of this on the results of this review, however, the fact that we found such bias indicates the importance for researchers to publish the results of all trials.

The findings of this review should be considered in the context of the general medical management of patients with cancer.

\section{AUTHORS' CONCLUSIONS}

\section{Implications for practice}

For patients being treated for cancer the clinical dilemma is whether to prevent, treat or leave oral candidiasis. For treating or preventing oral candidiasis, drugs absorbed from the gastrointestinal tract should be prescribed. Overall there is no evidence that drugs not absorbed are effective, however there is weak evidence that amphotericin B may possibly be of benefit.

\section{Implications for research}

Consideration needs to be given to developing and standardising clinical diagnostic criteria and the use of patient based outcomes. 


\section{ACKN OWLEDGEMENTS}

Thanks go to Anne Littlewood, Trials Search Co-ordinator for the Cochrane Oral Health Group for carrying out the searches for the review, Luisa Fernandez (Managing Editor) and Phil Riley (Assistant Managing Editor) for the Oral Health Group for their help with the administration of the review which included sending out letters to authors and locating all the articles.

The help and expertise of the following is gratefully acknowledged: Marco Esposito (Italian translations; The University of Manchester), Tatiana Macfarlane (Russian translations; The University of Manchester) and Mikako Hayashi (Japanese translations; University of Osaka) for providing translations of the trial reports and completing the data extraction forms.
We would also like to thank the following investigators who replied to our request for additional information about their trials: GP Bodey (Texas Medical Center), H Brincker (Odense University Hospital), PH Chandrasekar (Wayne State University School of Medicine), J Epstein (University of British Columbia), GA Ferretti (University of Kentucky), J Ninane (Covance, Belgium), J Palmblad (Huddinge Hospital, Sweden), J Philpott-Howard (University of London), C Rotstein (McMaster University, Canada), M Rozenberg-Arska (Universitair Medisch Centrum, Utrecht), A Schaffner (University Hospital Zurich), YB Wahlin (University of Umea), C Williams (Cochrane Cancer Network).

We would also like to thank those who have provided comments and editorial input into this review. 


\section{R E F E R E N C E S}

\section{References to studies included in this review}

Bodey 1990 \{published data only\}

* Bodey GP, Samonis G, Rolston K. Prophylaxis of candidiasis in cancer patients. Seminars in Oncology 1990;17(3):24-8.

Samonis G, Rolston K, Karl C, Miller P, Bodey GP. Prophylaxis of oropharyngeal candidiasis with fluconazole. Reviews of Infectious Diseases 1990;12(3):S369-73.

Brincker 1978 \{published data only\}

Brincker H. Prophylactic treatment with miconazole and patients highly predisposed to fungal infection. A placebocontrolled double-blind study. Acta Medica Scandinavica 1978;204(1-2):123-8.

\section{Brincker 1983 \{published data only\}}

Brincker $\mathrm{H}$. Prevention of mycosis in granulocytopenic patients with prophylactic ketoconazole treatment. Mykosen 1983;26(5):242-7.

\section{Buchanan 1985 \{published data only\}}

Buchanan AG, Riben PD, Rayner EN, Parker SE, Ronald AR, Louie TJ. Nystatin prophylaxis of fungal colonization and infection in granulocytopenic patients: correlation of colonization and clinical outcome. Clinical and Investigative Medicine 1985;8(2):139-47.

\section{Caselli 1990 \{published data only\}}

Caselli D, Arico M, Michelone G, Cavanna C, Nespoli L, Burgio GR. Antifungal chemoprophylaxis in cancer children: a prospective randomized controlled study. Microbiologica 1990;13(4):347-51.

\section{Cuttner 1986 \{published data only\}}

Cuttner J, Troy K, Funaro L, Brenden R, Bottons EJ. Clotrimazole is effective in preventing oropharyngeal candidiasis in patients with leukemia undergoing chemotherapy. Proceedings of ASCO 1985;4:258.

${ }^{\star}$ Cuttner J, Troy KM, Funaro L, Brenden R, Bottone EJ. Clotrimazole treatment for prevention of oral candidiasis in patients with acute leukemia undergoing chemotherapy. Results of a double-blind study. The American Journal of Medicine 1986;81(5):771-4.

\section{Egger 1995 \{published data only\}}

Egger T, Gratwohl A, Tichelli A, Uhr M, Stebler Gysi C, Passweg J, et al. Comparison of fluconazole with oral polyenes in the prevention of fungal infections in neutropenic patients. A prospective, randomized, single-center study. Support Care Cancer 1995;3(2):139-46.

\section{Epstein 1992 \{published data only\}}

Epstein JB, Vickars L, Spinelli J, Reece D. Efficacy of chlorhexidine and nystatin rinses in prevention or oral complications in leukemia and bone marrow transplantation. Oral Surgery, Oral Medicine, and Oral Pathology 1992;73(6):682-9.
Ferretti 1988 \{published data only\}

Ferretti GA, Ash RC, Brown AT, Largent BM, Kaplan A, Lillich TT. Chlorhexidine for prophylaxis against oral infections and associated complications in patients receiving bone marrow transplants. Journal of the American Dental Association 1987;114(4):461-7.

* Ferretti GA, Ash RC, Brown AT, Parr MD, Romond EH, Lillich TT. Control of oral mucositis and candidiasis in marrow transplantation: a prospective, double-blind trial of chlorhexidine digluconate oral rinse. Bone Marrow Transplantation 1988;3(5):483-93.

\section{Giorgis 1991 \{published data only\}}

Giorgis GE, Galietti F, Massaglia GM, Ardizzi A, Barberis S, Peragine $P$, et al. Prevention of oropharyngeal mycosis using thymostimulin in patients with inoperable bronchogenic carcinoma [Prevenzione delle micosi orofaringee mediante timostomolina nei pazienti affetti da carcinoma broncogeno inoperabile]. Minerva Pneumologica 1991;30:133-5.

\section{Hann 1982 \{published data only\}}

Hann IM, Prentice HG, Corringham R, Blacklock HA, Keaney M, Shannon M, et al. Ketoconazole versus nystatin plus amphotericin $B$ for fungal prophylaxis in severely immunocompromised patients. The Lancet 1982;1(8276):826-9.

\section{Huijgens 1999 \{published data only\}}

Huijgens PC, Simoons-Smit AM, van Loenen AC, Proovy E, van Tinteren $\mathrm{H}$, Ossenkoppele $\mathrm{GJ}$, et al. Fluconazole versus itraconazole for the prevention of fungal infections in haematooncology. Journal of Clinical Pathology 1999;52(5):376-80.

\section{Menichetti 1994 \{published data only\}}

Menichetti F, Del Favero A, Martino P, Bucaneve G, Micozzi A, $D$ 'Antonio $D$, et al. Preventing fungal infection in neutropenic patients with acute leukemia: fluconazole compared with oral amphotericin B. Annals of Internal Medicine 1994;120(11):913-8.

\section{Menichetti 1999 \{published data only\}}

Menichetti F, Del Favero A, Martino P, Bucaneve G, Micozzi A, Girmenia C, et al. Intraconazole oral solution as prophylaxis for fungal infections in neutropenic patients with hematologic malignancies: a randomized, placebo-controlled, double-blind, multicenter trial. Clinical Infectious Diseases 1999;28(2):250-5.

\section{Ninane 1994 \{published data only\}}

Groll AH, Just-Nuebling G, Kurz M, Mueller C, Nowak-Goettl U, Schwabe $\mathrm{D}$, et al. Fluconazole versus nystatin in the prevention of candida infections in children and adolescents undergoing remission induction or consolidation chemotherapy for cancer. Journal of Antimicrobial Chemotherapy 1997;40(6):855-62.

* Ninane J. A multicentre study of fluconazole versus oral polyenes in the prevention of fungal infection in children with hematological or oncological malignancies. European Journal of Clinical Microbiology \& Infectious Diseases 1994;13(4):330-7. 
Nucci 2000 \{published data only\}

Nucci M, Biasoli I, Akiti T, Silveira F, Solza C, Barreiros G, et al. A double-blind, randomized, placebo-controlled trial of itraconazole capsules as antifungal prophylaxis for neutropenic patients. Clinical Infectious Diseases 2000;30(2):300-5.

\section{Orlandi 1986 \{published data only\}}

Orlandi E, Bernasconi C, Michelone G, Cavanna C, Lombardi G. Mycotic infections in patients affected by acute myeloid leukemia. Clinical-microbiological evaluation of a protocol of anti-mycotic prophylaxis [Infezioni micotiche in pazienti affetti da leucemia acuta mieloide. Valutazione clinico-microbiologica di un protocollo dio profilassi antimicotica]. Giornale di Malattie Infettive e Parassitarie 1986;38(12):1434-7.

\section{Owens 1984 \{published data only\}}

Owens NJ, Nightingale CH, Schweizer RT, Schauer PK, Dekker PT, Quintiliani R. Prophylaxis of oral candidiasis with clotrimazole troches. Archives of Internal Medicine 1984;144(2):290-3.

\section{Palmblad 1992 \{published data only\}}

Palmblad J, Lonnqvist B, Carlsson B, Grimfors G, Jarnmark M, Lerner R, et al. Oral ketoconazole prophylaxis for Candida infections during induction therapy for acute leukaemia in adults: more bacteraemias. Journal of Internal Medicine 1992;231(4):363-70.

\section{Philpott-Howard 1993 \{published data only\}}

Philpott-Howard JN, Wade JJ, Mufti GJ, Brammer KW, Ehninger G. Randomized comparison of oral fluconazole versus oral polyenes for the prevention of fungal infection in patients at risk of neutropenia. Journal of Antimicrobial Chemotherapy 1993;31(6):973-84.

\section{Rozenberg-Arska 1991 \{published data only\}}

Rozenberg-Arska M, Dekker AW, Branger J, Verhoef J. A randomized study to compare oral fluconazole to amphotericin $B$ in the prevention of fungal infections in patients with acute leukaemia. Journal of Antimicrobial Chemotherapy 1991;27(3):369-76

\section{Scrimgeour 1985 \{published data only\}}

Scrimgeour E, Anderson JD. Ketoconazole prophylaxis in patients with solid tumours receiving aggressive immunosuppressive therapy. South African Medical Journal 1985;67(26):1044-5

\section{Vogler 1987 \{published data only\}}

Vogler WR, Malcom LG, Winton EF. A randomized trial comparing ketoconazole and nystatin prophylactic therapy in neutropenic patients. Cancer Investigation 1987;5(4):267-73.

\section{Wahlin 1989 \{published data only\}}

Wahlin YB. Effects of chlorhexidine mouthrinse on oral health in patients with acute leukemia. Oral Surgery, Oral Medicine, and Oral Pathology 1989;68(3):279-87.

\section{Williams 1977 \{published data only\}}

Williams C, Whitehouse JM, Lister TA, Wrigley PF. Oral anticandidal prophylaxis in patients undergoing chemotherapy for acute leukemia. Medical and Pediatric Oncology 1977;3(3):275-80

Winston 1993 \{published data only\}

Chandrasekar PH, Gatny CM. The effect of fluconazole prophylaxis on fungal colonization in neutropenic cancer patients. Journal of Antimicrobial Chemotherapy 1994;33(2):309-18.

Goodman JL, Winston DJ, Greenfield RA, Chandrasekar PH, Fox $\mathrm{B}$, Kaizer $\mathrm{H}$, et al. A controlled trial of fluconazole to prevent fungal infections in patients undergoing bone marrow transplantation. New England Journal of Medicine 1992;326(13):845-51.

* Winston DJ, Chandrasekar PH, Lazarus HM, Goodman JL, Silber JL, Horowitz $\mathrm{H}$, et al. Fluconazole prophylaxis of fungal infections in patients with acute leukemia. Results from a randomised placebo-controlled, double-blind, multicentre trial. Annals of Internal Medicine 1993;118(7):495-503.

\section{Yamada 1993 \{published data only\}}

Yamada T, Dan K, Nomura T. Prevention of bacterial and fungal infections in acute leukemia patients: a new and potent combination of oral norfloxacin and amphotericin B. Internal Medicine 1993;32(9):710-5.

Yeo 1985 \{published data only\}

Yeo E, Alvarado T, Fainstein V, Bodey GP. Prophylaxis of oropharyngeal candidiasis with clotrimazole. Journal of Clinical Oncology 1985;3(12):1668-71.

\section{References to studies excluded from this review}

\section{Akiyama 1993 \{published data only\}}

Akiyama H, Mori S, Tanikawa S, Sakamaki H, Onozawa Y. Fluconazole versus oral amphotericin $\mathrm{B}$ in preventing fungal infection in chemotherapy-induced neutropenic patients with haematological malignancies. Mycoses 1993;36(11-12):373-8.

\section{Annaloro 1995 \{published data only\}}

Annaloro C, Oriana A, Tagliaferri E, Bertolli V, Della Volpe A, Soligo $D$, et al. Efficacy of different prophylactic antifungal regimens in bone marrow transplantation. Haematologica 1995;80(6):512-7.

\section{Biancofiore 2002 \{published data only\}}

Biancofiore G, Bindi ML, Baldassarri R, Romanelli AM, Catalano G, Filipponi F, et al. Antifungal prophylaxis in liver transplant recipients: a randomized placebo-controlled study. Transplantation International 2002;15(7):341-7.

Bodey 1994a \{published data only\}

Bodey GP, Anaissie EJ, Elting LS, Estey E, O'Brien S, Kantarjian $\mathrm{H}$. Antifungal prophylaxis during remission induction therapy for acute leukemia fluconazole versus intravenous amphotericin B. Cancer 1994;73(8):2099-106.

\section{Bodey 1994b \{published data only\}}

Bodey GP, Anaissie E, Gutterman J, Vadhan-Raj S. Role of granulocyte-macrophage colony-stimulating factor as adjuvant 
treatment in neutropenic patients with bacterial and fungal infection. European Journal of Clinical Microbiology \& Infectious Diseases 1994;13 Suppl 2:S18-22.

\section{Boogaerts 2001 \{published data only\}}

Boogaerts M, Maertens J, van Hoof A, de Bock R, Fillet G, Peetermans $\mathrm{M}$, et al. Itraconazole versus amphotericin $\mathrm{B}$ plus nystatin in the prophylaxis of fungal infections in neutropenic cancer patients. Journal of Antimicrobial Chemotherapy 2001;48(1):97-103.

\section{Brammer 1990 \{published data only\}}

Brammer KW. Management of fungal infection in neutropenic patients with fluconazole. Haematology and Blood Transfusion 1990;33:546-50.

\section{Cagnoni 2000 \{published data only\}}

Cagnoni PJ, Walsh TJ, Prendergast MM, Bodensteiner D, Hiemenz S, Greenberg RN, et al. Pharmacoeconomic analysis of liposomal amphotericin B versus conventional amphotericin $B$ in the empirical treatment of persistently febrile neutropenic patients. Journal of Clinical Oncology 2000;18(12):2476-83.

\section{Cagnoni 2002 \{published data only\}}

Cagnoni PJ. Liposomal amphotericin B versus conventional amphotericin B in the empirical treatment of persistently febrile neutropenic patients. Journal of Antimicrobial Chemotherapy 2002;49 Suppl 1:81-6.

\section{Charak 1988 \{published data only\}}

Charak BS, Parikh PM, Banavali SD, Modi A, Saikia TK, Gopal R, et al. Comparison of clotrimazole with nystatin in preventing oral candidiasis in neutropaenic patients. Indian Journal of Medical Research 1988;88:416-20.

\section{Ellis 1994 \{published data only\}}

Ellis ME, Clink H, Ernst P, Halim MA, Padmos A, Spence D, et al. Controlled study of fluconazole in the prevention of fungal infections in neutropenic patients with haematological malignancies and bone marrow transplant recipients. European Journal of Clinical Microbiology \& Infectious Disease 1994;13(1):3-11.

\section{EORTC 1989 \{published data only\}}

EORTC International Antimicrobial Therapy Cooperative Group. Empiric antifungal therapy in febrile granulocytopenic patients. The American Journal of Medicine 1989;86(6 Pt 1):668-72.

\section{Epstein 1996 \{published data only\}}

Epstein JB, Ransier A, Lunn R, Chin E, Jacobson JJ, Le N, et al. Prophylaxis of candidiasis in patients with leukemia and bone marrow transplants. Oral Surgery, Oral Medicine, Oral Pathology, Oral Radiology and Endodontics 1996;81(3):291-6.

\section{Epstein 2004 \{published data only\}}

Epstein JB, Truelove EL, Hanson-Huggins K, Mancl LA, Chen A, Press OW, et al. Topical polyene antifungals in hematopoietic cell transplant patients: tolerability and efficacy. Supportive Care in Cancer: Official Journal of the Multinational Association of Supportive Care in Cancer 2004;12(7):517-25.
Ezdinli 1971 \{published data only\}

Ezdinli E, Desai D, Knill J. Prophylaxis of candidiasis with oral amphotericin B. Proceedings of the American Association for Cancer Research 1971;12:19.

\section{Finke 1990 \{published data only\}}

Finke R. Comparison of oral fluconazole and amphotericin B prophylaxis against fungal infections in the neutropenic phase of patients treated with antileukemic agents [German]. Mycoses 1990;33 Suppl 1:42-54.

\section{Gava 1996 \{published data only\}}

Gava A, Ferrarese F, Tonetto V, Coghetto F, Marazzato G, Zorat PL. Can fluconazole for mycotic mucositis improve radiation therapy of head and neck cancer?. La Radiologia Medica 1996;91(4):452-5.

\section{Glasmacher 2006 \{published data only\}}

Glasmacher A, Cornely O, Ullmann AJ, Wedding U, Bodenstein $\mathrm{H}$, Wandt $\mathrm{H}$, et al. An open-label randomized trial comparing itraconazole oral solution with fluconazole oral solution for primary prophylaxis of fungal infections in patients with haematological malignancy and profound neutropenia. Journal of Antimicrobial Chemotherapy 2006;57(2):317-25.

\section{Goranov 1999 \{published data only\}}

Goranov S, Spasov E, Grudeva-Popova J, Vakrilov V. Antifungal prophylaxis with low doses fluconazole in patients with hematological malignancies. Folia Medica 1999;41(4):68-72.

\section{Gozdasoglu 1999 \{published data only\}}

Gozdasoglu S, Ertem M, Buyukkececi Z, Yavuzdemir S, Bengisun S, Ozenci $\mathrm{H}$, et al. Fungal colonization and infection in children with acute leukemia and lymphoma during induction therapy. Medical Pediatric Oncology 1999;32(5):344-8.

\section{Gualtieri 1983 \{published data only\}}

Gualtieri RJ, Donowitz GR, Kaiser DL, Hess CE, Sande MA. Double-blind randomized study of prophylactic trimethoprim/ sulfamethoxazole in granulocytopenic patients with hematologic malignancies. The American Journal of Medicine 1983;74(6):934-40.

\section{Gurwith 1979 \{published data only\}}

Gurwith MJ, Brunton JL, Lank BA, Harding GK, Ronald AR. A prospective controlled investigation of prophylactic trimethoprim/sulfamethoxazole in hospitalized granulocytopenic patients. The American Journal of Medicine 1979;66(2):248-56.

\section{Hansen 1987 \{published data only\}}

Hansen RM, Reinerio N, Sohnle PG, Abrams RA, Ritch PS, Libnoch JA, et al. Ketoconazole in the prevention of candidiasis in patients with cancer. A prospective, randomized, controlled, double-blind study. Archives of Internal Medicine 1987;147(4):710-2.

\section{Harousseau 1998 \{published data only\}}

Harousseau JL, Dekker A, Stamatoullas A, Bassaris H, Linkesch W, Fassas A, et al. Prophylaxis of fungal infections in haematological malignancies: A double blind trial comparing 
itraconazole oral solution to amphotericin B capsules. Blood 1998;92 (10 Suppl 1 (Pt 2)):53b (Abstract 3202).

\section{Harousseau 2000 \{published data only\}}

Harousseau JL, Dekker AW, Stamatoullas-Bastard A, Fassas A, Linkesch W, Gouveia J, et al. Itraconazole oral solution for primary prophylaxis of fungal infections in patients with hematological malignancy and profound neutropenia: a randomized, double-blind, double-placebo, multicenter trial comparing itraconazole and amphotericin B. Antimicrobial Agents and Chemotherapy 2000;44(7):1887-93.

\section{Hiemenz 2005 \{published data only\}}

Hiemenz J, Cagnoni P, Simpson D, Devine S, Chao N, Keirns J, et al. Pharmacokinetic and maximum tolerated dose study of micafungin in combination with fluconazole versus fluconazole alone for prophylaxis of fungal infections in adult patients undergoing a bone marrow or peripheral stem cell transplant. Antimicrobial Agents \& Chemotherapy 2005;49(4):1331-6.

\section{Hoppe 1995 \{published data only\}}

Hoppe JE, Friess D, Niethammer D. Orointestinal yeast colonization of paediatric oncologic patients during antifungal prophylaxis: results of quantitative culture and Candida serology and comparison of three polyenes. Mycoses 1995;38(1-2):41-9.

\section{Jones 1984 \{published data only\}}

Jones PG, Kauffman CA, McAuliffe LS, Liepman MK, Bergman AG. Efficacy of ketoconazole $v$ nystatin in prevention of fungal infections in neutropenic patients. Archives of Internal Medicine 1984;144(3):549-51.

\section{Kaptan 2003 \{published data only\}}

Kaptan K, Ural AU, Cetin T, Avcu F, Beyan C, Yalcin A. Itraconazole is not effective for the prophylaxis of fungal infections in patients with neutropenia. Journal of Infection and Chemotherapy 2003;9(1):40-5.

\section{Kelsey 1999 \{published data only\}}

Kelsey SM, Goldman JM, McCann S, Newland AC, Scarffe JH, Oppenheim BA, et al. Liposomal amphotericin (AmBisome) in the prophylaxis of fungal infections in neutropenic patients: a randomised, double-blind, placebo-controlled study. Bone Marrow Transplantation 1999;23(2):163-8.

Kern 1991 \{published data only\}

Kern W, Kurrle E. Ofloxacin versus trimethoprimsulfamethoxazole for prevention of infection in patients with acute leukemia and granulocytopenia. Infection 1991;19(2):73-80.

\section{Koc 2003 \{published data only\}}

Koc M, Aktas E. Prophylactic treatment of mycotic mucositis in radiotherapy of patients with head and neck cancers. Japanese Journal of Clinical Oncology 2003;33(2):57-60.

\section{Lass-Florl 2003 \{published data only\}}

Lass-Florl C, Gunsilius E, Gastl G, Englisch M, Koch G, Ulmer H, et al. Fungal colonization in neutropenic patients: a randomized study comparing itraconazole solution and amphotericin $B$ solution. Annals of Hematology 2003;82(9):565-9.

Laverdiere 2000 \{published data only\}

Laverdiere M, Rotstein C, Bow EJ, Roberts RS, loannou S, Carr D, et al. Impact of fluconazole prophylaxis on fungal colonization and infection rates in neutropenic patients. Journal of Antimicrobial Chemotherapy 2000;46(6):1001-8.

Malcolm 1982 \{published data only\}

Malcolm LG, Vogler WR, Winton EF. A phase iii trial comparing ketoconazole (R41400) and nystatin in the prevention of oral candidiasis and invasive fungal infections in the neutropenic immunosuppressed. ASCO Abstracts 1982;62:62.

\section{Malik 1998 \{published data only\}}

Malik IA, Moid I, Aziz Z, Khan S, Suleman M. A randomized comparison of fluconazole with amphotericin $B$ as empiric anti-fungal agents in cancer patients with prolonged fever and neutropenia. The American Journal of Medicine 1998;105(6):478-83.

\section{Marr 2004 \{published data only\}}

Marr KA, Crippa F, Leisenring W, Hoyle M, Boeckh M, Balajee SA, et al. Itraconazole versus fluconazole for prevention of fungal infections in patients receiving allogeneic stem cell transplants. Blood 2004;103(4):1527-33.

\section{Marr 2004b \{published data only\}}

Marr KA, Leisenring W, Crippa F, Slattery JT, Corey L, Boeckh M, et al. Cyclophosphamide metabolism is affected by azole antifungals. Blood 2004;103(4):1557-9.

\section{Mattiuzzi 2003 \{published data only\}}

Mattiuzzi GN, Estey E, Raad I, Giles F, Cortes J, Shen Y, et al. Liposomal amphotericin $B$ versus the combination of fluconazole and itraconazole as prophylaxis for invasive fungal infections during induction: chemotherapy for patients with acute myelogenous leukemia and myelodysplastic syndrome. Cancer 2003;97(2):450-6.

\section{Mattiuzzi 2006 \{published data only\}}

Mattiuzzi GN, Alvarado G, Giles FJ, Ostrosky-Zeichner L, Cortes J, O'Brien S, et al. Open-label, randomized comparison of itraconazole versus caspofungin for prophylaxis in patients with hematologic malignancies. Antimicrobial Agents \& Chemotherapy 2006;50(1):143-7.

\section{Meunier 1989 \{published data only\}}

Meunier-Carpentier F, Leleux A, Snoeck R, Gerain J, Lambert C, Ceuppens AM. Chemoprophylaxis of fungal infections. In: K Holmberg, R Meyer editor(s). Diagnosis and therapy of systemic fungal infections. New York: Raven Press Ltd, 1989.

\section{Meunier 1991 \{published data only\}}

Meunier-Carpentier F, Aoun M, Janssens M, Dekoster C, Paesmans M. Chemoprophylaxis of fungal infections in granulocytopenic patients using fluconazole vs oral amphotericin B. Drug Investigation 1991;3(4):258-65. 
Meunier-C 1983 \{published data only\}

Meunier-Carpentier F, Cruciani M, Klastersky J. Oral prophylaxis with miconazole or ketoconazole of invasive fungal disease in neutropenic cancer patients. European Journal of Cancer \& Clinical Oncology 1983;19(1):43-8.

\section{Milliken 1989 \{published data only\}}

Milliken S, Gore M, Powles R, Harding M, Jameson B, Talbot D, et al. Fluconazole versus polyenes as oral anti-fungal prophylaxis in autologous and allogeneic bone marrow recipients (abstract). Bone Marrow Transplantation 1989;4(Suppl 2):27.

Mitrokhin 2003 \{published data only\}

Mitrokhin SD. [Itraconazole (Orungal) in the treatment of mycotic infections in oncologic patients]. [Russian]. Antibiotiki $i$ Khimioterapiia 2003;48(2):16-21.

\section{Morgenstern 1999 \{published data only\}}

Morgenstern GR, Prentice AG, Prentice HG, Ropner JE, Schey SA, Warnock DW. A randomized controlled trial of itraconazole versus fluconazole for the prevention of fungal infections in patients with haematological malignancies. U.K. Multicentre Antifungal Prophylaxis Study Group. British Journal of Haematology 1999;105(14):901-11.

\section{Mucke 1997 \{published data only\}}

Mucke R, Kaben U, Libera T, Knauerhase H, Ziegler PG, Hamann D, et al. [Use of fluconazole as antimycotic prophylaxis in radiotherapy of patients with head and neck tumors]. [German]. Mycoses 1997;40 Suppl 1:53-5.

\section{Nicolatou 2003 \{published data only\}}

Nicolatou-Galitis O, Sotiropoulou-Lontou A, Velegraki A Pissakas G, Kolitsi G, Kyprianou K, et al. Oral candidiasis in head and neck cancer patients receiving radiotherapy with amifostine cytoprotection. Oral Oncology 2003;39(4):397-401.

\section{Nicolatou 2006 \{published data only\}}

Nicolatou-Galitis O, Velegraki A, Sotiropoulou-Lontou A, Dardoufas K, Kouloulias V, Kyprianou K, et al. Effect of fluconazole antifungal prophylaxis on oral mucositis in head and neck cancer patients receiving radiotherapy. Supportive Care in Cancer 2006;14(1):44-51.

\section{Noguchi 2000 \{published data only\}}

Noguchi I, Sato Y, Ando T, Takahashi M, Kurokawa H, Kimishima Y, et al. A study of the prophylactic effect of the oral antifungal agent itraconazole against oral cavity candidiasis in patients receiving radiation therapy for oral cavity carcinoma. Therapeutics and Pharmacology 2000;19(2):45-50.

\section{Nomura 2006 \{published data only\}}

Nomura K, Kawasugi K, Morimoto T. Cost-effectiveness analysis of antifungal treatment for patients on chemotherapy. European Journal of Cancer Care 2006;15(1):44-50.

\section{Paiva 1994 \{published data only\}}

Paiva JA, Brandao T, Milheiro R, Maia AM, Lameirao A, Alves, et al. Comparative study of two different fluconazole dosages as anti-fungal prophylaxis in neutropenic patients [Estudo comparativo de duas doses de fluconazol na profilaxia de infeccoes fungicas em doentes neutropenicos]. Arquivos de Medicina 1994;8(2):69-72.

Peterson 1984 \{published data only\}

Peterson PK, McGlave P, Ramsay NK, Rhame F, Goldman Al, Kersey J. Empirical antibacterial therapy in febrile, granulocytopenic bone marrow transplant patients. Antimicrobial Agents and Chemotherapy 1984;26(2):136-8.

Prentice 1989 \{published data only\}

Prentice AG, Bradford GR. Prophylaxis of fungal infections with itraconazole during remission-induction therapy. Mycoses 1989;32 Suppl 1:96-102.

\section{Priour 1995 \{published data only\}}

Priour A. Prevention of mucositis [La prevention des mucites]. Soins. Pediatrie, Puericulture 1995;166:32-3. [MEDLINE: 96322145]

\section{Ringden 2002 \{published data only\}}

Ringden O. Ten years' experience with liposomal amphotericin B in transplant recipients at Huddinge University Hospital. Journal of Antimicrobial Chemotherapy 2002;49 Suppl 1:51-5.

Rotstein 1999 \{published data only\}

Rotstein C, Bow EJ, Laverdiere M, Ioannou S, Carr D, Moghaddam N. Randomized placebo-controlled trial of fluconazole prophylaxis for neutropenic cancer patients: benefit based on purpose and intensity of cytotoxic therapy. Clinical Infectious Diseases 1999;28(2):331-40.

\section{Schaffner 1995 \{published data only\}}

Schaffner A, Schaffner M. Effect of prophylactic fluconazole on the frequency of fungal infections, amphotericin B use, and health care costs in patients undergoing intensive chemotherapy for hematologic neoplasias. The Journal of Infectious Diseases 1995;172(4):1035-41.

\section{Schaison 1990 \{published data only\}}

Schaison G, Baruchel A, Arlet G. Prevention of gram-positive and Candida albicans infections using teicoplanin and fluconazole: a randomized study in neutropenic children. British Journal of Haematology 1990;76 Suppl 2:24-6.

\section{Shepp 1985 \{published data only\}}

Shepp DH, Klosterman A, Siegel MS, Meyers JD. Comparative trial of ketoconazole and nystatin for prevention of fungal infection in neutropenic patients treated in a protective environment. The Journal of Infectious Diseases 1985;152(6):1257-63.

\section{Silling 1998 \{published data only\}}

Silling G, Fegeler W, Roos N, Boes C, Schomaker R, Essink M, et al. [Traitement empirique precoce chez des patients neutropeniques en hematologie: etude comparative randomisee fluconazole versus amphotericine B/ 5-flucytosine]. Hematologie 1998;4(II):19-23.

Silling 1999 \{published data only\}

Silling G, Fegeler W, Roos N, Essink M, Buchner T. Early empiric antifungal therapy of infections in neutropenic patients 
comparing fluconazole with amphotericin B/flucytosine. Mycoses 1999;42 Suppl 2:101-4.

\section{Sleijfer 1980 \{published data only\}}

Sleijfer DT, Mulder NH, de Vries-Hospers HG, Fidler V, Nieweg HO, van der Waaij D, et al. Infection prevention in granulocytopenic patients by selective decontamination of the digestive tract. European Journal of Cancer 1980;16(6):859-69.

\section{Subira 2004b \{published data only\}}

Subira M, Martino R, Gomez L, Marti JM, Estany C, Sierra J. Low-dose amphotericin B lipid complex vs. conventional amphotericin $B$ for empirical antifungal therapy of neutropenic fever in patients with hematologic malignancies - a randomized, controlled trial. European Journal of Haematology 2004;72(5):342-7.

\section{Timmers 2000 \{published data only\}}

Timmers GJ, Zweegman S, Simoons-Smit AM, van Loenen AC, Touw D, Huijgens PC. Amphotericin B colloidal dispersion (Amphocil) vs fluconazole for the prevention of fungal infections in neutropenic patients: data of a prematurely stopped clinical trial. Bone Marrow Transplantation 2000;25(8):879-84.

\section{Tollemar 1994 \{published data only\}}

Tollemar J, Hockerstedt K, Ericzon BG, Sundberg B, Ringden O. Fungal prophylaxis with AmBisome in liver and bone marrow transplant recipients: results of two randomized double-blind studies. Transplant Proceedings 1994;26(3):1833.

\section{Turhan 1987 \{published data only\}}

Turhan A, Connors JM, Klimo P. Ketoconazole versus nystatin as prophylaxis against fungal infection for lymphoma patients receiving chemotherapy. American Journal of Clinical Oncology 1987;10(4):355-9.

\section{Urabe 1990 \{published data only\}}

Urabe A, Takaku F, Mizoguchi H, Nomura T, Ogawa T, Maekawa T, et al. Prophylactic and therapeutic effects of oral administration of amphotericin B in mycosis associated with hematologic diseases. Study Group of Mycosis in Hematologic Disease. Japanese Journal of Antibiotics 1990;43(1):116-30.

\section{Van't Wout 1991 \{published data only\}}

van't Wout JW, Novakova I, Verhagen CA, Fibbe WE, de Pauw BE, van der Meer JW. [Therapy of systemic mycoses in neutropenic patients using itraconazole. A comparative, randomized study with amphotericin B] [German]. Medizinische Klinik 1991;86 Suppl 1:11-3.

\section{Vehreschild 2007 \{published data only\}}

Vehreschild JJ, Bohme A, Buchheidt D, Arenz D, Harnischmacher U, Heussel CP, et al. A double-blind trial on prophylactic voriconazole (VRC) or placebo during induction chemotherapy for acute myelogenous leukaemia (AML). The Journal of Infection 2007;55(5):445-9.

\section{Vreugdenhil 1993 \{published data only\}}

Vreugdenhil G, Van Dijke BJ, Donnelly JP, Novakova IR, Raemaekers JM, Hoogkamp-Korstanje MA, et al. Efficacy of itraconazole in the prevention of fungal infections among neutropenic patients with hematologic malignancies and intensive chemotherapy. A double blind, placebo controlled study. Leukemia and Lymphoma 1993;11(5-6):353-8.

\section{Walsh 1991 \{published data only\}}

Walsh TJ, Rubin M, Hathorn J, Gress J, Thaler M, Skelton J, et al. Amphotericin B vs high-dose ketoconazole for empirical antifungal therapy among febrile, granulocytopenic cancer patients. A prospective, randomized study. Archives of Internal Medicine 1991;151(4):765-70.

\section{Walsh 2002a \{published data only\}}

Walsh TJ, Pappas P, Winston DJ, Lazarus HM, Petersen F, Raffalli J, et al. Voriconazole compared with liposomal amphotericin B for empirical antifungal therapy in patients with neutropenia and persistent fever. New England Journal of Medicine 2002;346(4):225-34.

Walsh 2002b \{published data only\}

Walsh TJ, Lutsar I, Driscoll T, Dupont B, Roden M, Ghahramani P, et al. Voriconazole in the treatment of aspergillosis, scedosporiosis and other invasive fungal infections in children. The Pediatric Infectious Disease Journal 2002;21(3):240-8.

\section{Walsh 2004 \{published data only\}}

Walsh TJ, Teppler H, Donowitz GR, Maertens JA, Baden LR, Dmoszynska A, et al. Caspofungin versus liposomal amphotericin $B$ for empirical antifungal therapy in patients with persistent fever and neutropenia. New England Journal of Medicine 2004;351(14):1391-402.

\section{Wang 2003 \{published data only\}}

Wang CY, Wu BY, Guo KY. A controlled clinical trial of itraconazole for prevention of fungal infections secondary to chemotherapy. Di Yi Jun Yi Da Xue Xue Bao 2003;23(4):389-90.

\section{Weiser 1981 \{published data only\}}

Weiser B, Lange M, Fialk MA, Singer C, Szatrowski TH, Armstrong D. Prophylactic trimethoprim-sulfamethoxazole during consolidation chemotherapy for acute leukemia: a controlled trial. Annals of Internal Medicine 1981;95(4):436-8.

\section{Winston 2000 \{published data only\}}

Winston DJ, Hathorn JW, Schuster MG, Schiller GJ, Territo MC. A multicenter, randomized trial of fluconazole versus amphotericin B for empiric antifungal therapy of febrile neutropenic patients with cancer. The American Journal of Medicine 2000;108(4):282-9.

\section{Wolff 2000 \{published data only\}}

Wolff SN, Fay J, Stevens D, Herzig RH, Pohlman B, Bolwell B, et al. Fluconazole vs low-dose amphotericin B for the prevention of fungal infections in patients undergoing bone marrow transplantation: a study of the North American Marrow Transplant Group. Bone Marrow Transplantation 2000;25(8):853-9.

\section{Yamac 1995 \{published data only\}}

Yamac K, Senol E, Haznedar R. Prophylactic use of fluconazole in neutropenic cancer patients. Postgraduate Medical Journal 1995;71(835):284-6. 
Young 1999 \{published data only\}

Young GA, Bosly A, Gibbs DL, Durrant S. A double-blind comparison of fluconazole and nystatin in the prevention of candidiasis in patients with leukaemia. Antifungal Prophylaxis Study Group. European Journal of Cancer 1999;35(8):1208-13.

Zacharof 1999 \{published data only\}

Zacharof AK, Petrogiannopoulos C, Zacharof H. Empirical antifungal therapy among febrile granulocytopenic cancer patients. Supportive Care in Cancer 1999;7 Supp(Abstr. P-96):189.

\section{References to studies awaiting assessment}

\section{Corvo 2008 \{published data only\}}

Corvo R, Amichetti M, Ascarelli A, Arcangeli G, Buffoli A, Cellini N, et al. Effects of fluconazole in the prophylaxis of oropharyngeal candidiasis in patients undergoing radiotherapy for head and neck tumour: results from a double-blind placebo-controlled trial. European Journal of Cancer Care 2008;17(3):270-7.

\section{Elad 2006 \{published data only\}}

Elad S, Wexler A, Garfunkel AA, Shapira MY, Bitan M, Or R. Oral candidiasis prevention in transplantation patients: a comparative study. Clinical Transplantation 2006;20(3):318-24.

\section{Additional references}

\section{Begg 1994}

Begg CB, Mazumdar M. Operating characteristics of a rank correlation test for publication bias. Biometrics 1994;50(4):1088-101.

\section{Clarkson 2007}

Clarkson JE, Worthington HV, Eden TOB. Interventions for treating oral mucositis for patients with cancer receiving treatment. Cochrane Database of Systematic Reviews 2007, Issue 2. [Art. No.: CD001973. DOI: 10.1002/14651858.CD001973.pub3]

\section{De Pauw 1997}

De Pauw BE. Practical modalities for prevention of fungal infections in cancer patients. European Journal of Clinical Microbiology \& Infectious Diseases 1997;16(1):32-41.

\section{Egger 1997}

Egger M, Davey Smith G, Schneider M, Minder C. Bias in meta-analysis detected by a simple, graphical test. $B M J$ 1997;315(7109):629-34.

\section{CHARACTERISTICS OF STUDIES}

Characteristics of included studies [ordered by study ID]

\section{Gotzsche 2002}

Gøtzsche PC, Johansen HK. Routine versus selective antifungal administration for control of fungal infections in patients with cancer. Cochrane Database of Systematic Reviews 2002, Issue 2. [Art. No.: CD000026. DOI: 10.1002/14651858.CD000026]

\section{Sharp 1998}

Sharp S. Meta-analysis regression. Stata Technical Bulletin 1998;42:16-22.

\section{Worthington 2007}

Worthington HV, Clarkson JE, Eden TOB. Interventions for treating oral candidiasis for patients with cancer receiving treatment. Cochrane Database of Systematic Reviews 2007, Issue 2. [Art. No.: CD001972. DOI: 10.1002/14651858.CD001972.pub3]

\section{Worthington 2007a}

Worthington HV, Clarkson JE, Eden TOB. Interventions for preventing oral mucositis for patients with cancer receiving treatment. Cochrane Database of Systematic Reviews 2007, Issue 4. [Art. No.: CD000978. DOI: 10.1002/14651858.CD000978.pub3]

\section{References to other published versions of this review \\ Clarkson 2000}

Clarkson JE, Worthington HV, Eden OB. Prevention of oral mucositis or oral candidiasis for patients with cancer receiving chemotherapy (excluding head and neck cancer). Cochrane Database of Systematic Reviews 2000, Issue 1.

\section{Clarkson 2007a}

Clarkson JE, Worthington HV, Eden TOB. Interventions for preventing oral candidiasis for patients with cancer receiving treatment. Cochrane Database of Systematic Reviews 2007, Issue 1. [DOI: 10.1002/14651858.CD003807.pub3]

\section{Worthington 2002}

Worthington HV, Clarkson JE, Eden TOB. Interventions for preventing oral candidiasis for patients with cancer receiving treatment. Cochrane Database of Systematic Reviews 2002, Issue 3. [DOI: 10.1002/14651858.CD003807]

\section{Worthington 2004b}

Worthington HV, Eden OB, Clarkson JE. Interventions for preventing oral candidiasis for patients with cancer receiving treatment. Cochrane Database of Systematic Reviews 2004, Issue 4. [Art. No.: CD003807. DOI: 10.1002/14651858.CD003807.pub2]

* Indicates the major publication for the study

Bodey 1990

Methods Randomised, parallel group study conducted in USA. Patient, provider and assessor blinded. Unclear information on reasons for withdrawal. Dentist not involved in the study. Drop outs: $23 \%$. 
Bodey 1990 (Continued)

Participants Adults with solid cancer. 146 eligible patients, with 112 completing.

Interventions 2 groups, placebo versus fluconazole (50 mg once per day from 48 hours of admission). Duration: 4
weeks.

Outcomes Both clinical and mycological assessment of oral candidiasis at 4 weeks.

Other outcomes: none.

\section{Notes}

\section{Risk of bias}

\begin{tabular}{lll}
\hline Bias & Authors' judgement & Support for judgement \\
\hline $\begin{array}{l}\text { Allocation concealment } \\
\text { (selection bias) }\end{array}$ & Low risk & A - Adequate \\
\hline
\end{tabular}

\section{Brincker 1978}

Methods Randomised, parallel group study conducted in Denmark. Patient, provider, assessor blinded. Clear in-
formation on reasons for withdrawal. Dentist not involved in the study. Drop outs: $17 \%$.

\begin{tabular}{|c|c|c|}
\hline Participants & \multicolumn{2}{|c|}{ Adults with blood cancer. 30 eligible patients, 30 enrolled and 25 completed. } \\
\hline Interventions & \multicolumn{2}{|c|}{$\begin{array}{l}2 \text { groups, placebo versus miconazole ( } 500 \mathrm{mg} 4 \text { times per day ( } 250 \mathrm{mg} \text { tablets)). Duration: at least } 3 \\
\text { weeks (max } 25 \text { days). }\end{array}$} \\
\hline Outcomes & \multicolumn{2}{|c|}{$\begin{array}{l}\text { Both clinical and mycological assessment of oral candidiasis at } 3 \text { weeks, maximum } 25 \text { days. } \\
\text { Other outcomes: none. }\end{array}$} \\
\hline \multicolumn{3}{|l|}{ Notes } \\
\hline \multicolumn{3}{|l|}{ Risk of bias } \\
\hline Bias & Authors' judgement & Support for judgement \\
\hline $\begin{array}{l}\text { Allocation concealment } \\
\text { (selection bias) }\end{array}$ & Low risk & A - Adequate \\
\hline
\end{tabular}

\section{Brincker 1983}

\begin{tabular}{ll}
\hline Methods & $\begin{array}{l}\text { Randomised, parallel group study conducted in Denmark. Patient, carer, assessor blinded. Clear infor- } \\
\text { mation on withdrawals. Dentist not involved in the study. Drop outs: } 0 \% .\end{array}$ \\
\hline Participants & Adults with blood cancer. 38 patients enrolled, 38 completed. \\
\hline Interventions & 2 groups, placebo versus ketoconazole (400 mg per day). Duration: 4 weeks. \\
\hline Outcomes & $\begin{array}{l}\text { Clinical assessment of oral candidiasis at } 4 \text { weeks. } \\
\text { Other outcomes: systemic fungal infection. }\end{array}$ \\
\hline Notes & \\
\hline
\end{tabular}


Brincker 1983 (Continued)

Risk of bias

\begin{tabular}{lll}
\hline Bias & Authors' judgement & Support for judgement \\
\hline $\begin{array}{l}\text { Allocation concealment } \\
\text { (selection bias) }\end{array}$ & Low risk & A - Adequate \\
\hline
\end{tabular}

Buchanan 1985

Methods Randomised, parallel group study conducted in Canada. Patient and provider not blinded, unclear if as-
sessor blinded. Clear information on withdrawals. Dentist not involved in the study. Drop outs: $0 \%$.

\begin{tabular}{ll}
\hline Participants & Adults with mixed cancer. 164 eligible patients, 78 enrolled and 78 completed. \\
\hline Interventions & $\begin{array}{l}2 \text { groups, control = no treatment versus nystatin (1 million units as suspension }(100,000 \mathrm{u} / \mathrm{ml} \text { every } 4 \\
\text { hours). Gargle for } 3 \text { to } 5 \text { minutes before swallowing). Duration: } 8 \text { weeks. }\end{array}$
\end{tabular}

Outcomes Mycological assessment of oral candidiasis at 8 weeks.

Other outcomes: none.

Notes All patients had oral trimethoprim and sulfamethoxazole.

\section{Risk of bias}

\begin{tabular}{lll}
\hline Bias & Authors' judgement & Support for judgement \\
\hline $\begin{array}{l}\text { Allocation concealment } \\
\text { (selection bias) }\end{array}$ & Unclear risk & B - Unclear \\
\hline
\end{tabular}

Caselli 1990

\begin{tabular}{ll}
\hline Methods & $\begin{array}{l}\text { Randomised, parallel group study conducted in Italy. Patient, carer not blinded, assessor blinded. Clear } \\
\text { information on withdrawals. Dentist not involved in the study. Drop outs: } 0 \% .\end{array}$ \\
\hline Participants & Children with blood cancer. 40 patients eligible, enrolled, and completed. \\
\hline $\begin{array}{l}\text { Interventions } \\
\text { photericin-B }(50 \mathrm{mg} / \mathrm{kg} \text { daily in } 2 \text { doses). Duration: } 4 \text { weeks. }\end{array}$ \\
\hline Outcomes & $\begin{array}{l}\text { Mycological assessment of oral candidiasis at } 4 \text { weeks. } \\
\text { Other outcomes: systemic fungal infection. }\end{array}$ \\
\hline Notes & All receiving prophylactic cotrimoxazole (thrimetoprim $5 \mathrm{mg} / \mathrm{kg}$ daily). \\
\hline Risk of bias & Authors' judgement Support for judgement \\
\hline Bias & Unclear risk $\quad$ B - Unclear \\
\hline $\begin{array}{l}\text { Allocation concealment } \\
\text { (selection bias) }\end{array}$ & \\
\hline
\end{tabular}


Cuttner 1986

\begin{tabular}{ll}
\hline Methods & $\begin{array}{l}\text { Randomised, parallel group study conducted in USA. Patient, carer, assessor blinded. Clear information } \\
\text { on withdrawals. Dentist not involved in the study. Drop outs } 0 \% .\end{array}$ \\
\hline Participants & $\begin{array}{l}\text { Adults with blood cancer. } 42 \text { eligible patients, 28 enrolled and } 28 \text { completed. Patients had negative } \\
\text { smears for entry into study. }\end{array}$ \\
\hline Interventions & $\begin{array}{l}2 \text { groups placebo versus clotrimazole (10 mg troche } 3 \text { times per day, dissolved for } 15 \text { to } 30 \text { minutes, } \\
\text { then swallowed). Duration: } 8 \text { weeks. }\end{array}$ \\
\hline Outcomes & $\begin{array}{l}\text { Mycological assessment of oral candidiasis at } 8 \text { weeks. } \\
\text { Other outcomes: toxicity (adverse events 'probably due to drug'). }\end{array}$ \\
\hline Notes & $\begin{array}{l}\text { Authors' judgement Support for judgement } \\
\text { Risk of bias }\end{array}$ \\
\hline Bias & Low risk \\
\hline $\begin{array}{l}\text { Allocation concealment } \\
\text { (selection bias) }\end{array}$ \\
\hline
\end{tabular}

\section{Egger 1995}

Methods Randomised, parallel group study conducted in Switzerland. Patient, carer not blinded, oucome asses-
sor blinded. Unclear which group the 1 withdrawal was in. Drop outs: $1 \%$.

\begin{tabular}{ll} 
Participants & $\begin{array}{l}\text { Adults and children }>14 \text { with blood cancer. } 90 \text { randomised, } 1 \text { not evaluable as cultures after randomi- } \\
\text { sation were positive for Aspergillus, but unclear which group he was in, } 157 \text { eligible. } 30 \text { patients had al- } \\
\text { logenic and } 3 \text { autologous bone marrow transplants. }\end{array}$ \\
\hline Interventions & $\begin{array}{l}2 \text { groups high dose oral/intravenous fluconazole ( } 400 \mathrm{mg} \text { daily) versus nystatin suspension (24x10E6 } \\
\text { units } 3 \text { times per day) plus miconazole (Daktarin) inhalations } 3 \text { times daily for } 10 \text { minutes. }\end{array}$
\end{tabular}

\begin{tabular}{|c|c|c|}
\hline Outcomes & \multicolumn{2}{|c|}{$\begin{array}{l}\text { Mycological assessment of oral candidiasis at } 2 \text { weeks. } \\
\text { Other outcomes: systemic fungal infection, death associated with fungal infection, empirical antifungal } \\
\text { treatment, toxicity (adverse events 'probably due to drug'), good compliance. }\end{array}$} \\
\hline Notes & \multicolumn{2}{|c|}{$\begin{array}{l}\text { Patients admitted to isolation unit. Nystatin administration difficult for patients receiving therapy for } \\
\text { more than } 2 \text { weeks. }\end{array}$} \\
\hline \multicolumn{3}{|l|}{ Risk of bias } \\
\hline Bias & Authors' judgement & Support for judgement \\
\hline $\begin{array}{l}\text { Allocation concealment } \\
\text { (selection bias) }\end{array}$ & Unclear risk & B - Unclear \\
\hline
\end{tabular}

Epstein 1992

Methods

Randomised, parallel group study conducted in Canada. Patient and provider not blinded, unclear if assessor blinded. Unclear information on reasons for withdrawal. Dentist involved in the study. Drop outs: $13 \%$. 
Epstein 1992 (Continued)

Participants Adults with blood cancer. 99 patients eligible and enrolled and 86 completed.

\begin{tabular}{ll}
\hline Interventions & 4 groups, control = saline $(15 \mathrm{ml}$ rinse) versus chlorhexidine $(0.2 \% 15 \mathrm{ml}$ rinse), nystatin $(100,000 \mathrm{u} / \mathrm{ml}$ \\
& $15 \mathrm{ml}$ rinse), chlorhexidine + nystatin (as above). All interventions were used 4 times daily for 1 minute. \\
& Duration: 3 weeks.
\end{tabular}

\begin{tabular}{|c|c|}
\hline Outcomes & $\begin{array}{l}\text { Mycological assessment of oral candidiasis at } 3 \text { weeks. } \\
\text { Other outcomes: none. }\end{array}$ \\
\hline \multicolumn{2}{|l|}{ Notes } \\
\hline \multicolumn{2}{|l|}{ Risk of bias } \\
\hline Bias & Authors' judgement Support for judgement \\
\hline $\begin{array}{l}\text { Allocation concealment } \\
\text { (selection bias) }\end{array}$ & A - Adequate \\
\hline
\end{tabular}

\section{Ferretti 1988}

Methods $\quad$ Randomised, parallel group study conducted in USA. Patient, provider and assessor blinded. Unclear
information on reasons for withdrawals. Dentist involved in the study. Drop outs: $9 \%$.

\begin{tabular}{|c|c|c|}
\hline Participants & \multicolumn{2}{|c|}{ Adults and children with blood cancer. 56 enrolled and 51 completed. } \\
\hline Interventions & \multicolumn{2}{|c|}{2 groups placebo versus chlorhexidine ( $15 \mathrm{ml}$ for 30 seconds 3 times daily). Duration: up to 90 days. } \\
\hline Outcomes & \multicolumn{2}{|c|}{$\begin{array}{l}\text { Both clinical and mycological assessment of oral candidiasis at } 9 \text { weeks. } \\
\text { Other outcomes: systemic fungal infection, death associated with fungal infection. }\end{array}$} \\
\hline \multicolumn{3}{|l|}{ Notes } \\
\hline \multicolumn{3}{|l|}{ Risk of bias } \\
\hline Bias & Authors' judgement & Support for judgement \\
\hline $\begin{array}{l}\text { Allocation concealment } \\
\text { (selection bias) }\end{array}$ & Low risk & A - Adequate \\
\hline
\end{tabular}

\section{Giorgis 1991}

\begin{tabular}{ll}
\hline Methods & $\begin{array}{l}\text { Randomised, parallel group study conducted in Italy. Patient blinded, provider and assessor not blind- } \\
\text { ed. Clear information on withdrawals. Dentist not involved in the study. Drop outs: } 27 \% .\end{array}$ \\
\hline Participants & Adults with solid cancer. 48 eligible and enrolled, 13 died and 35 completed. \\
\hline Interventions & 2 groups placebo versus thymostimulin (50 to 70 mg twice per week) Duration: 4 to 9 months. \\
\hline Outcomes & $\begin{array}{l}\text { Mycological assessment of oral candidiasis at } 52 \text { weeks. } \\
\text { Other outcomes: none. }\end{array}$ \\
\hline Notes & Translated from Italian.
\end{tabular}


Giorgis 1991 (Continued)

Risk of bias

\begin{tabular}{lll}
\hline Bias & Authors' judgement & Support for judgement \\
\hline $\begin{array}{l}\text { Allocation concealment } \\
\text { (selection bias) }\end{array}$ & Unclear risk & B - Unclear \\
\hline
\end{tabular}

\section{Hann 1982}

\begin{tabular}{ll} 
Methods & $\begin{array}{l}\text { Randomised, parallel group study conducted in UK. Patient and provider not blinded, assessor blinded. } \\
\text { Clear information on withdrawals. Dentist not involved in the study. Drop outs: } 5 \% .\end{array}$ \\
\hline Participants & Adults and children with mixed cancer. 76 patients eligible, enrolled and 72 completed. \\
\hline Interventions & $\begin{array}{l}2 \text { groups, ketoconazole }(400 \mathrm{mg} / \text { day in adults, } 200 \mathrm{mg} / \text { day in children) versus amphotericin B lozenges } \\
(10 \mathrm{mg} 4 \text { times daily) }+ \text { nystatin tablets }(0.5 \text { megaunits twice daily + nystatin suspension }(0.1 \text { megaunits } \\
\text { twice daily). Duration: } 9 \text { weeks. }\end{array}$
\end{tabular}
Outcomes Both clinical and mycological assessment of oral candidiasis at 9 weeks or when neutrophil count was $>1 \times 10$ E9/l.
Other outcomes: systemic fungal infection, death associated with fungal infection, empirical antifungal treatment.

\begin{tabular}{ll}
\hline Notes & Patients were given oral neomycin sulphate (500 mg twice daily), colistin (1.5 megaunits twice daily), \\
trimoxazole (trimethoprim $160 \mathrm{mg}$ plus sulphamethoxazole $800 \mathrm{mg}$ every 12 hours).
\end{tabular}

\section{Risk of bias}

\begin{tabular}{lll}
\hline Bias & Authors' judgement & Support for judgement \\
\hline $\begin{array}{l}\text { Allocation concealment } \\
\text { (selection bias) }\end{array}$ & Unclear risk & B - Unclear \\
\hline
\end{tabular}

\section{Huijgens 1999}

$\begin{array}{ll}\text { Methods } & \text { Randomised, parallel group study conducted in Holland. Patient, provider and assessor blinded. Un- } \\ \text { clear information on reasons for withdrawal. Dentist not involved in the study. Drop outs: } 5 \% .\end{array}$

\begin{tabular}{ll}
\hline Participants & Adults with blood cancer. 213 patients enrolled and 202 completed. \\
\hline Interventions & $\begin{array}{l}2 \text { groups fluconazole ( } 50 \mathrm{mg} \text { twice daily) versus itraconazole (100 mg twice daily). Duration: } 10 \text { to } 12 \\
\text { days. }\end{array}$ \\
\hline Outcomes & $\begin{array}{l}\text { Both clinical and mycological assessment of oral candidiasis at 10-12 days. } \\
\text { Other outcomes: systemic fungal infection, death associated with fungal infection, empirical antifungal } \\
\text { treatment, toxicity (adverse events 'probably due to drug'), compliance. }\end{array}$
\end{tabular}

Notes Patients received ciprofloxacin 500 mg twice daily, roxitromycin 150 mg twice daily. Nasal amphotericin was given $2 \mathrm{mg} 3$ times per day.

\section{Risk of bias}

\section{Bias \\ Authors' judgement Support for judgement}

Interventions for preventing oral candidiasis for patients with cancer receiving treatment (Review) 
Huijgens 1999 (Continued)

\begin{tabular}{l}
$\begin{array}{l}\text { Allocation concealment } \\
\text { (selection bias) }\end{array}$ \\
\hline
\end{tabular}

Menichetti 1994

Methods Randomised, parallel group multicentre study conducted in Italy. Patient and provider not blinded, unclear if assessor blinded. Clear information on withdrawals. Dentist not involved in the study. Drop outs: $0 \%$.

\begin{tabular}{ll}
\hline Participants & Adults and children with blood cancer. 820 eligible patients in 30 centres, 820 completed. \\
\hline Interventions & $\begin{array}{l}\text { 2 groups fluconazole ( } 150 \mathrm{mg} \text { once daily capsule) versus amphotericin B suspension (500 mg every } 6 \\
\text { hours). Started interventions } 1 \text { to } 3 \text { days prior to chemo. }\end{array}$ \\
\hline Outcomes & $\begin{array}{l}\text { Both clinical and mycological assessment of oral candidiasis when neutrophil count was }>1000 / \text { uL. } \\
\text { Other outcomes: systemic fungal infection, death associated with fungal infection, empirical antifungal } \\
\text { treatment, toxicity (adverse events 'probably due to drug'), compliance. }\end{array}$ \\
\hline Notes & All patients received oral ciprofloxacin 500 mg twice daily).
\end{tabular}

Risk of bias

\begin{tabular}{lll}
\hline Bias & Authors' judgement & Support for judgement \\
\hline $\begin{array}{l}\text { Allocation concealment } \\
\text { (selection bias) }\end{array}$ & Unclear risk & B - Unclear \\
\hline
\end{tabular}

\section{Menichetti 1999}

Rethods
Randomised, parallel group multicentre study conducted in Italy. Patient, provider and assessor blind-
$0 \%$. Clear information on withdrawals. Unclear whether dentist was involved in the study. Drop outs:

\begin{tabular}{ll}
\hline Participants & Adults with blood cancer. 405 eligible patients in 39 centres. 405 completed. \\
\hline Interventions & $\begin{array}{l}2 \text { groups placebo versus itraconazole (oral solution } 2.5 \mathrm{mg} / \mathrm{kg} \text { daily, } 100 \mathrm{mg} \text { of itraconazole per } 10 \mathrm{ml} \text { of } \\
\text { cyclodextrin). Started intervention } 1 \text { to } 3 \text { days before chemo. Duration: } 8 \text { weeks maximum. }\end{array}$ \\
\hline Outcomes & $\begin{array}{l}\text { Both clinical and mycological assessment of oral candidiasis when neutrophil count was }>1000 / \mathrm{uL}, \\
\text { maximum } 8 \text { weeks. } \\
\text { Other outcomes: systemic fungal infection, death associated with fungal infection, toxicity (adverse } \\
\text { events 'probably due to drug'), compliance. }\end{array}$
\end{tabular}

Notes All patients received nystatin 500,000 U 4 times a day, and oral ciprofloxacin $500 \mathrm{mg}$ twice daily.

\section{Risk of bias}

\begin{tabular}{lll}
\hline Bias & Authors' judgement & Support for judgement \\
\hline $\begin{array}{l}\text { Allocation concealment } \\
\text { (selection bias) }\end{array}$ & Unclear risk & B - Unclear \\
\hline
\end{tabular}


Ninane 1994

Methods

Randomised, parallel group multi-centre study conducted in Europe. Patient, provider and assessor blinded (c). Clear information on withdrawals 'may have been associated with side effects' (c). Dentist not involved in the study. Drop outs: $3 \%$.

\begin{tabular}{ll}
\hline Participants & Children with mixed cancer. 502 patients enrolled and 485 completed. \\
\hline Interventions & 2 groups, fluconazole suspension ( $3 \mathrm{mg} / \mathrm{kg}$ body weight) versus polyenes (nystatin oral suspension \\
& $\begin{array}{l}50,000 \mathrm{U} / \mathrm{kg} \text { body weight or amphotericin B oral suspension } 25 \mathrm{mg} / \mathrm{kg} \text { body weight both given daily in } 4 \\
\text { doses). Duration: } 4 \text { weeks. }\end{array}$
\end{tabular}

Outcomes Both clinical and mycological assessment of oral candidiasis at 4 weeks, or until remission.

Other outcomes: systemic fungal infection, toxicity (adverse events 'probably due to drug').

Notes

\section{Risk of bias}

\begin{tabular}{lll}
\hline Bias & Authors' judgement & Support for judgement \\
\hline $\begin{array}{l}\text { Allocation concealment } \\
\text { (selection bias) }\end{array}$ & Low risk & A - Adequate \\
\hline
\end{tabular}

Nucci 2000

Methods Randomised, parallel group study conducted in Brazil. Patient, provider and assessor blinded. Clear in-
formation on withdrawals. Dentist not involved in the study. Drop outs: $4 \%$.

\begin{tabular}{|c|c|c|}
\hline Participants & \multicolumn{2}{|c|}{ Adults and children with mixed cancer. 219 patients enrolled and 210 completed. } \\
\hline Interventions & \multicolumn{2}{|c|}{$\begin{array}{l}2 \text { groups, placebo versus itraconazole ( } 100 \mathrm{mg} \text { capsules every } 12 \text { hours at mealtimes). Duration: } 3 \\
\text { weeks. }\end{array}$} \\
\hline Outcomes & \multicolumn{2}{|c|}{$\begin{array}{l}\text { Both clinical and mycological assessment of oral candidiasis at } 3 \text { weeks. } \\
\text { Other outcomes: systemic fungal infection, death associated with fungal infection, empirical antifunga } \\
\text { treatment, toxicity (adverse events 'probably due to drug'), compliance. }\end{array}$} \\
\hline \multicolumn{3}{|l|}{ Notes } \\
\hline \multicolumn{3}{|l|}{ Risk of bias } \\
\hline Bias & Authors' judgement & Support for judgement \\
\hline $\begin{array}{l}\text { Allocation concealment } \\
\text { (selection bias) }\end{array}$ & Low risk & A - Adequate \\
\hline
\end{tabular}

Orlandi 1986

$\begin{array}{ll}\text { Methods } & \text { Randomised, parallel group study conducted in Italy. Patient and provider not blinded, unclear if asses- } \\ \text { sor blinded. Clear information on withdrawals. Unclear whether dentist was involved in the study. Drop } \\ \text { outs: } 40 \% \text {. }\end{array}$


Orlandi 1986 (Continued)

Participants Adults with blood cancer. 30 patients enrolled and 18 completed.

\begin{tabular}{ll}
\hline Interventions & $\begin{array}{l}2 \text { groups, control = no treatment versus amphotericin B (500 mg tablets slowly chewed). Duration: until } \\
\text { remission of cancer. }\end{array}$
\end{tabular}

\begin{tabular}{ll}
\hline Outcomes & $\begin{array}{l}\text { Both clinical and mycological assessment of oral candidiasis. } \\
\text { Other outcomes: none. }\end{array}$ \\
\hline Notes & $\begin{array}{l}\text { Translated from Italian. If temperature gave antibiotics cefalosporine and gentamicina, all patients had } \\
\text { corticosteroids. }\end{array}$
\end{tabular}

\section{Risk of bias}

\begin{tabular}{lll}
\hline Bias & Authors' judgement & Support for judgement \\
\hline $\begin{array}{l}\text { Allocation concealment } \\
\text { (selection bias) }\end{array}$ & Unclear risk & B - Unclear \\
\hline
\end{tabular}

\section{Owens 1984}

Methods $\quad$ Randomised, parallel group study conducted in USA. Patient, provider and assessor blinded. Unclear
information on reasons for withdrawals. Dentist not involved in the study. Drop outs: $81 \%$.

\begin{tabular}{|c|c|c|}
\hline Participants & \multicolumn{2}{|c|}{ Adults with mixed cancer. 84 patients enrolled 16 completed. } \\
\hline Interventions & \multicolumn{2}{|c|}{$\begin{array}{l}2 \text { groups, placebo versus clotrimazole ( } 10 \mathrm{mg} 3 \text { times daily dissolved in mouth). Duration: leukaemia } \\
\text { mean }=27 \text { days, neoplasm mean }=37 \text { days. }\end{array}$} \\
\hline Outcomes & \multicolumn{2}{|c|}{$\begin{array}{l}\text { Both clinical and mycological assessment of oral candidiasis at } 4 \text { weeks. } \\
\text { Other outcomes: systemic fungal infection, empirical antifungal treatment, toxicity (adverse events } \\
\text { 'probably due to drug'). }\end{array}$} \\
\hline \multicolumn{3}{|l|}{ Notes } \\
\hline \multicolumn{3}{|l|}{ Risk of bias } \\
\hline Bias & Authors' judgement & Support for judgement \\
\hline $\begin{array}{l}\text { Allocation concealment } \\
\text { (selection bias) }\end{array}$ & Low risk & A - Adequate \\
\hline
\end{tabular}

Palmblad 1992

$\begin{array}{ll}\text { Methods } & \text { Randomised, parallel group study conducted in Sweden. Patient, provider and assessor blinded. Clear } \\ \text { information on withdrawals. Dentist not involved in the study. Drop outs: } 8 \% .\end{array}$

\begin{tabular}{ll}
\hline Participants & Adults with blood cancer. 116 newly diagnosed patients enrolled and 107 completed. \\
\hline Interventions & $\begin{array}{l}2 \text { groups, placebo versus ketoconazole (200 mg daily). Duration: continued until complete remission di- } \\
\text { agnosed, blood granulocyte level up, patient discharged or died. }\end{array}$
\end{tabular}

Outcomes Both clinical and mycological assessment of oral candidiasis.


Palmblad 1992 (Continued)

Other outcomes: systemic fungal infection, death associated with fungal infection.

Notes

\section{Risk of bias}

\begin{tabular}{lll}
\hline Bias & Authors' judgement & Support for judgement \\
\hline $\begin{array}{l}\text { Allocation concealment } \\
\text { (selection bias) }\end{array}$ & Unclear risk & B - Unclear \\
\hline
\end{tabular}

Philpott-Howard 1993

\begin{tabular}{ll} 
Methods & $\begin{array}{l}\text { Randomised, parallel group multicentre study conducted in Europe. Patient, provider and outcome as- } \\
\text { sessor not blinded. Clear information on withdrawals. Dentist not involved in the study. Drop outs: } 5 \% .\end{array}$ \\
\hline Participants & Adults and children with mixed cancer. 536 eligible, 536 enrolled and 511 completed. \\
\hline Interventions & $\begin{array}{l}2 \text { groups, fluconazole }(50 \mathrm{mg} \text { per day) versus polyenes (nystatin or amphotericin B) (4x10E6 units, } 2 \mathrm{~g} \\
\text { doses per day). Treatment began before chemo/radio. Duration: continued until neutrophil count }> \\
10 \mathrm{E} 9 / \mathrm{L}, \text { usually } 4 \text { weeks, } 12 \text { weeks maximum. }\end{array}$ \\
\hline Outcomes & $\begin{array}{l}\text { Both clinical and mycological assessment of oral candidiasis at } 4 \text { weeks, or when neutrophil count was } \\
>1 \times 10 E 9 / l, \text { maximum } 12 \text { weeks. } \\
\text { Other outcomes: systemic fungal infection, toxicity (adverse events 'probably due to drug'). }\end{array}$ \\
\hline
\end{tabular}

Notes

\section{Risk of bias}

\begin{tabular}{lll}
\hline Bias & Authors' judgement & Support for judgement \\
\hline $\begin{array}{l}\text { Allocation concealment } \\
\text { (selection bias) }\end{array}$ & Low risk & A - Adequate \\
\hline
\end{tabular}

Rozenberg-Arska 1991

Randomised, parallel group study conducted in Holland. Patient, provider and assessor of clinical out-
come not blinded, assessor of mycological outcome blinded (c). Unclear information on reasons for
withdrawal. Dentist not involved in the study. Drop outs: $7 \%$.

\begin{tabular}{ll}
\hline Participants & Adults with blood cancer. 54 patients enrolled, 50 completed. \\
\hline Interventions & $\begin{array}{l}2 \text { groups, fluconazole ( } 50 \mathrm{mg} 1 \text { dose daily) versus amphotericin B (200 mg in suspension and } 200 \mathrm{mg} \text { in } \\
\text { tablets, } 4 \text { times per day). Duration: period of granulocytopenia, } 19 / 20 \text { days. }\end{array}$ \\
\hline Outcomes & $\begin{array}{l}\text { Both clinical and mycological at } 3 \text { weeks. } \\
\text { Other outcomes: systemic fungal infection, empirical antifungal treatment, toxicity (adverse events } \\
\text { 'probably due to drug'). }\end{array}$ \\
\hline
\end{tabular}

\section{Notes}

\section{Risk of bias}


Rozenberg-Arska 1991 (Continued)

\begin{tabular}{lll} 
Bias & Authors' judgement & Support for judgement \\
\hline $\begin{array}{l}\text { Allocation concealment } \\
\text { (selection bias) }\end{array}$ & Unclear risk & B - Unclear
\end{tabular}

\section{Scrimgeour 1985}

\begin{tabular}{ll}
\hline Methods & $\begin{array}{l}\text { Randomised, parallel group study conducted in South Africa. Unclear if patient, provider or assessor } \\
\text { blinded. Unclear information on reasons for withdrawal. Dentist not involved in the study. Drop outs: } \\
30 \% .\end{array}$
\end{tabular}

\begin{tabular}{|c|c|c|}
\hline Participants & \multicolumn{2}{|c|}{ Unclear whether adults or children, with solid cancer. 43 enrolled, 30 completed. } \\
\hline Interventions & \multicolumn{2}{|c|}{2 groups, ketoconazole $200 \mathrm{mg}$ versus ketoconazole $400 \mathrm{mg}$ daily. Duration: unclear. } \\
\hline Outcomes & \multicolumn{2}{|c|}{$\begin{array}{l}\text { Both clinical and mycological assessment of oral candidiasis weekly. } \\
\text { Other outcomes: toxicity (adverse events 'probably due to drug'). }\end{array}$} \\
\hline \multicolumn{3}{|l|}{ Notes } \\
\hline \multicolumn{3}{|l|}{ Risk of bias } \\
\hline Bias & Authors' judgement & Support for judgement \\
\hline $\begin{array}{l}\text { Allocation concealment } \\
\text { (selection bias) }\end{array}$ & Unclear risk & B - Unclear \\
\hline
\end{tabular}

\section{Vogler 1987}

$\begin{array}{ll}\text { Methods } & \text { Randomised, parallel group study conducted in USA. Patient and provider not blinded, unclear if asses- } \\ \text { sor blinded. Clear information on withdrawals. Dentist not involved in the study. Drop outs: } 10 \% .\end{array}$

\begin{tabular}{ll}
\hline Participants & Adults with blood cancer. 51 eligible patients and 46 completed. \\
\hline Interventions & $\begin{array}{l}2 \text { groups, ketoconazole ( } 200 \mathrm{mg} \text { twice daily) versus nystatin oral suspension }(500,000 \text { units } 4 \text { times dai- } \\
\text { ly). Duration: until absolute granulocyte count was }>1500 / \text { ul for } 2 \text { days. }\end{array}$ \\
\hline
\end{tabular}

\section{Outcomes}

Both clinical and mycological assessment of oral candidiasis.

Other outcomes: systemic fungal infection, toxicity (adverse events 'probably due to drug').

$$
\text { Notes }
$$

\section{Risk of bias}

\begin{tabular}{lll}
\hline Bias & Authors' judgement & Support for judgement \\
\hline $\begin{array}{l}\text { Allocation concealment } \\
\text { (selection bias) }\end{array}$ & Unclear risk & B - Unclear \\
\hline
\end{tabular}


Wahlin 1989

\begin{tabular}{ll}
\hline Methods & $\begin{array}{l}\text { Randomised, parallel group study conducted in Sweden. Patient, provider not blinded, but assessor } \\
\text { blinded. Clear information on withdrawals. Dentist involved in the study. Drop outs: } 0 \% .\end{array}$ \\
\hline Participants & Adults and children with blood cancer. 28 patients enrolled and 28 completed. \\
\hline Interventions & $\begin{array}{l}2 \text { groups control = no treatment versus chlorhexidine (10 ml of } 0.2 \% \text { chlorhexidine digluconate solu- } \\
\text { tion), twice daily. Duration: } 21 \text { days. }\end{array}$ \\
\hline Outcomes & $\begin{array}{l}\text { Both clinical and mycological assessment of oral candidiasis. } \\
\text { Other outcomes: none. }\end{array}$ \\
\hline Notes & First episode data for each patient used. \\
\hline Risk of bias & Authors' judgement Support for judgement \\
\hline Bias & Low risk $\quad$ A - Adequate \\
\hline $\begin{array}{l}\text { Allocation concealment } \\
\text { (selection bias) }\end{array}$ & \\
\hline
\end{tabular}

Williams 1977

\begin{tabular}{ll}
\hline Methods & Randomised, parallel group study conducted in UK. Patient, provider and assessor not blinded. Clear \\
information on withdrawals. Dentist not involved in the study. Drop outs: $0 \%$.
\end{tabular}

\begin{tabular}{ll}
\hline Participants & Adults and children with blood cancer. 56 patients eligible, enrolled and completed. \\
\hline Interventions & $\begin{array}{l}3 \text { groups control = no treatment versus nystatin ( } 100,000 \text { units in } 10 \mathrm{ml} \text { of methylcellulose }), \text { natamycin } \\
(10 \mathrm{ml} \text { of } 0.25 \% \text { suspension }) \text { both every } 2 \text { hours. Duration: } 50 \text { days. }\end{array}$ \\
\hline
\end{tabular}

Outcomes Clinical assessment of oral candidiasis at 7 weeks.

Other outcomes: none.

\section{Notes}

\section{Risk of bias}

\begin{tabular}{lll}
\hline Bias & Authors' judgement & Support for judgement \\
\hline $\begin{array}{l}\text { Allocation concealment } \\
\text { (selection bias) }\end{array}$ & Low risk & A - Adequate \\
\hline
\end{tabular}

Winston 1993

\begin{tabular}{ll}
\hline Methods & $\begin{array}{l}\text { Randomised, parallel group multicentre study conducted in USA. Patient, provider and assessor blind- } \\
\text { ed. Clear information on withdrawals. Dentist not involved in the study. Drop outs: }<1 \% .\end{array}$ \\
\hline Participants & Adults with blood cancer. 257 enrolled and 255 completed. \\
\hline Interventions & $\begin{array}{l}2 \text { groups, placebo versus fluconazole capsule (100 mg } 4 \text { times daily or administered intravenously - } 200 \\
\text { mg every } 12 \text { hours, infused over } 1 \text { hour }) . \text { Duration: through course of chemo until change of neutrophil } \\
\text { count reached } 1000 \text { cells per mm, maximum } 10 \text { weeks. }\end{array}$
\end{tabular}


Winston 1993 (Continued)

Outcomes
Mycological assessment of oral candidiasis at 10 weeks.

Other outcomes: systemic fungal infection, empirical antifungal treatment, toxicity (adverse events 'probably due to drug'). (Death was reported however it was unclear whether this was associated with a fungal infection.)

\section{Notes}

\section{Risk of bias}

\begin{tabular}{lll}
\hline Bias & Authors' judgement & Support for judgement \\
\hline $\begin{array}{l}\text { Allocation concealment } \\
\text { (selection bias) }\end{array}$ & Unclear risk & B - Unclear \\
\hline
\end{tabular}

\section{Yamada 1993}

\begin{tabular}{ll} 
Methods & $\begin{array}{l}\text { Randomised, parallel group study conducted in Japan. Patient and provider not blinded, unclear if as } \\
\text { sessor blinded. Clear information on withdrawals. Dentist not involved in the study. Drop outs: } 2 \% .\end{array}$ \\
\hline Participants & Adults with blood cancer. 111 patients enrolled, 109 completed. \\
\hline Interventions & $\begin{array}{l}2 \text { groups control = no treatment versus norofloxacin ( } 200 \mathrm{mg} \text { orally } 2 \text { or } 4 \text { times daily). Duration: } 4 \\
\text { weeks or until neutrophil count was }>1000 / \mathrm{uL} .\end{array}$
\end{tabular}

Outcomes Clinical assessment of oral candidiasis at 4 weeks or until neutrophil count was $>1000 / \mathrm{uL}$. Other outcomes: systemic fungal infection.

Notes Called "stomatitis".

\section{Risk of bias}

\begin{tabular}{lll}
\hline Bias & Authors' judgement & Support for judgement \\
\hline $\begin{array}{l}\text { Allocation concealment } \\
\text { (selection bias) }\end{array}$ & Unclear risk & B - Unclear \\
\hline
\end{tabular}

\section{Yeo 1985}

\begin{tabular}{ll}
\hline Methods & $\begin{array}{l}\text { Randomised, parallel group study conducted in USA. Patient, provider not blinded, but assessor blind- } \\
\text { ed. Unclear information on reasons for withdrawal. Dentist not involved in the study. Drop outs: 32\%. }\end{array}$ \\
\hline Participants & Adults with mixed cancer. 296 patients enrolled and 202 completed \\
\hline Interventions & $\begin{array}{l}2 \text { groups control = no treatment versus clotrimazole (10 mg troche } 3 \text { times daily - dissolve over } 15 \text { to } 20 \\
\text { minutes). Duration: } 8 \text { weeks. }\end{array}$
\end{tabular}

$\begin{array}{ll}\text { Outcomes } & \text { Both clinical and mycological assessment of oral candidiasis at } 8 \text { weeks. } \\ \text { Other outcomes: none. }\end{array}$

\section{Notes}

\section{Risk of bias}


Yeo 1985 (Continued)

\begin{tabular}{lll} 
Bias & Authors' judgement & Support for judgement \\
\hline $\begin{array}{l}\text { Allocation concealment } \\
\text { (selection bias) }\end{array}$ & Low risk & A-Adequate \\
\hline
\end{tabular}

Characteristics of excluded studies [ordered by study ID]

\begin{tabular}{|c|c|}
\hline Study & Reason for exclusion \\
\hline Akiyama 1993 & Episodes not patients. \\
\hline Annaloro 1995 & No useable outcome. \\
\hline Biancofiore 2002 & $\begin{array}{l}\text { Liver transplant patients (liposomal, amphotericin B + itraconazole versus fluconazole + itracona- } \\
\text { zole). }\end{array}$ \\
\hline Bodey 1994a & No oral outcome. \\
\hline Bodey 1994b & $\begin{array}{l}\text { Used as an empirical therapy only treating patients with documented infection. Episodes not pa- } \\
\text { tients (antibiotic therapy versus +/- GM-CFS). }\end{array}$ \\
\hline Boogaerts 2001 & No suitable outcomes (itraconazole versus amphotericin B + nystatin). \\
\hline Brammer 1990 & No oral outcome. \\
\hline Cagnoni 2000 & No useable outcomes (liposomal amphotericin B versus conventional amphotericin B). \\
\hline Cagnoni 2002 & Same study as Walsh 1999 but no suitable outcomes. \\
\hline Charak 1988 & $\begin{array}{l}\text { Not randomised although described as such (odd or even days of month). Episodes not patients } \\
\text { (clotrimazole versus nystatin). }\end{array}$ \\
\hline Ellis 1994 & No oral outcome. \\
\hline EORTC 1989 & $\begin{array}{l}\text { Used as an empirical therapy only treating patients with infection (amphotericin B versus no treat- } \\
\text { ment). }\end{array}$ \\
\hline Epstein 1996 & Not RCT (fluconazole). \\
\hline Epstein 2004 & $\begin{array}{l}\text { Inappropriate study design, some patients had oral candidiasis pre-treatment - not prophylaxis } \\
\text { (amphotericin B verus nystatin). }\end{array}$ \\
\hline Ezdinli 1971 & Inappropriate study design: autopsy study (amphotericin B versus placebo). \\
\hline Finke 1990 & No oral outcome. \\
\hline Gava 1996 & Episodes not patients. \\
\hline Glasmacher 2006 & Invasive fungal infection, no suitable outcomes (itraconazole versus fluconazole). \\
\hline Goranov 1999 & Not RCT (fluconazole versus no treatment). \\
\hline Gozdasoglu 1999 & Not RCT (none). \\
\hline
\end{tabular}




\begin{tabular}{|c|c|}
\hline Study & Reason for exclusion \\
\hline Gualtieri 1983 & No oral outcome. \\
\hline Gurwith 1979 & No oral outcome. \\
\hline Hansen 1987 & Episodes not patients. \\
\hline Harousseau 1998 & Abstract, insufficient information (itraconazole oral solution versus amphotericin B capsules). \\
\hline Harousseau 2000 & No oral outcome. \\
\hline Hiemenz 2005 & Interventions for systemic candidiasis not oral (micafungin + fluconazole versus fluconazole). \\
\hline Hoppe 1995 & No oral outcome. \\
\hline Jones 1984 & No useable data. \\
\hline Kaptan 2003 & Episodes not patients (itraconazole versus no treatment). \\
\hline Kelsey 1999 & $\begin{array}{l}\text { No suitable outcome as cannot separate superficial and systemic outcomes (amBisome versus } \\
\text { placebo). }\end{array}$ \\
\hline Kern 1991 & No oral outcome. \\
\hline Koc 2003 & $\begin{array}{l}\text { The outcome presented was symptomatic clinical candidiasis with grade } 3 \text { to } 4 \text { mucositis and oral } \\
\text { microbiological assessments confirming yeast. This outcome was not consistent with those for this } \\
\text { review. }\end{array}$ \\
\hline Lass-Florl 2003 & Colonisation prior to entry into the study. \\
\hline Laverdiere 2000 & No oral outcome. \\
\hline Malcolm 1982 & Abstract, insufficient information. \\
\hline Malik 1998 & $\begin{array}{l}\text { Used as an empirical therapy only treating patients with documented infection (fluconazole versus } \\
\text { amphotericin B). }\end{array}$ \\
\hline Marr 2004 & No oral outcomes given (cyclophosphamide). \\
\hline Marr 2004b & Primary outcome "invasive mould infections" and no oral outcomes mentioned (itraconazole). \\
\hline Mattiuzzi 2003 & $\begin{array}{l}\text { No suitable outcome - proven fungal infection but do not know if it is oral (itraconazole versus am- } \\
\text { photericin B). }\end{array}$ \\
\hline Mattiuzzi 2006 & Interventions for systemic candidiasis not oral (itraconazole versus caspofungin). \\
\hline Meunier 1989 & Episodes not patients, patients re-randomised into study. \\
\hline Meunier 1991 & Episodes not patients. \\
\hline Meunier-C 1983 & No oral outcome. \\
\hline Milliken 1989 & Abstract, insufficient information. \\
\hline Mitrokhin 2003 & Not RCT (Russian) (itraconazole). \\
\hline
\end{tabular}




\begin{tabular}{|c|c|}
\hline Study & Reason for exclusion \\
\hline Morgenstern 1999 & Episodes not patients (itraconazole versus fluconazole). \\
\hline Mucke 1997 & Not RCT. \\
\hline Nicolatou 2003 & Not RCT, confirmed by authors (amifostine). \\
\hline Nicolatou 2006 & Not RCT. \\
\hline Noguchi 2000 & Unclear if RCT or not (written to author, but no reply). \\
\hline Nomura 2006 & Not RCT (cost effectiveness). \\
\hline Paiva 1994 & Not RCT (Portuguese - translated) (fluconazole). \\
\hline Peterson 1984 & $\begin{array}{l}\text { No suitable outcomes (tobramycin and ticarcillin for either } 3 \text { days or until no longer glanulocy- } \\
\text { topenic). }\end{array}$ \\
\hline Prentice 1989 & Not RCT (itraconazole). \\
\hline Priour 1995 & No suitable outcome, (compliance not disease). \\
\hline Ringden 2002 & Not RCT (amphotericin B). \\
\hline Rotstein 1999 & No oral outcome. \\
\hline Schaffner 1995 & Episodes not patients. \\
\hline Schaison 1990 & No suitable outcome (teicoplanin versus fluconazole). \\
\hline Shepp 1985 & Data in wrong form (not patient based). \\
\hline Silling 1998 & $\begin{array}{l}\text { Used as an empirical therapy only treating patients with infection (fluconazole versus ampho- } \\
\text { tericin B). }\end{array}$ \\
\hline Silling 1999 & Same as Silling 1988 but in French (fluconazole versus amphotericin B). \\
\hline Sleijfer 1980 & Episodes not patients. \\
\hline Subira 2004b & Not prophylaxis as treatment of fever. \\
\hline Timmers 2000 & $\begin{array}{l}\text { Study halted early due to toxic effect of amphotericin B colloidal dispersion (amphocil) (flucona- } \\
\text { zole versus amphotericin B). }\end{array}$ \\
\hline Tollemar 1994 & Abstract of 2 RCTs, with insufficient data to include (AmBisome). \\
\hline Turhan 1987 & No oral outcome. \\
\hline Urabe 1990 & Not RCT. \\
\hline Van't Wout 1991 & Not RCT (German) (amphotericin B versus itraconazole). \\
\hline Vehreschild 2007 & Candidiasis is not a primary outcome. \\
\hline Vreugdenhil 1993 & No oral outcome. \\
\hline
\end{tabular}




\begin{tabular}{|c|c|}
\hline Study & Reason for exclusion \\
\hline Walsh 1991 & $\begin{array}{l}\text { Used as an empirical therapy only treating patients with infection (amphotericin versus ketocona- } \\
\text { zole). }\end{array}$ \\
\hline Walsh 2002a & $\begin{array}{l}\text { Used as an empirical therapy only treating patients with infection (voriconazole versus ampho- } \\
\text { tericin B). }\end{array}$ \\
\hline Walsh 2002b & Not RCT. \\
\hline Walsh 2004 & Empirical therapy only treating patients with infection (voriconazole versus ketoconazole). \\
\hline Wang 2003 & Unsure if RCT, and outcome is not oral. \\
\hline Weiser 1981 & Episodes not patients. \\
\hline Winston 2000 & $\begin{array}{l}\text { Used as an empirical therapy only treating patients with infection. No suitable outcome (flucona- } \\
\text { zole versus amphotericin B). }\end{array}$ \\
\hline Wolff 2000 & No suitable outcomes (fluconazole versus amphotericin B). \\
\hline Yamac 1995 & No suitable outcomes (fluconazole versus no treatment control). \\
\hline Young 1999 & Repeat enrolment of patients, which included people with oropharyngeal culture at entry. \\
\hline Zacharof 1999 & Abstract - insufficient information to include. \\
\hline
\end{tabular}

$\mathrm{RCT}=$ randomised controlled trial

Characteristics of studies awaiting assessment [ordered by study ID]

\section{Corvo 2008}

\begin{tabular}{ll} 
Methods & $\begin{array}{l}\text { Randomised, parallel group study conducted in } 20 \text { sites in Italy. Patient, provider and assessor } \\
\text { blinded. Clear information on withdrawals. Dentist not involved in the study. Drop outs: } 35 \% .\end{array}$ \\
\hline Participants & $\begin{array}{l}\text { Adults with solid cancer. } 270 \text { randomised (138 fluconazole, } 132 \text { placebo; } 2 \text { did not have post base- } \\
\text { line data) } 43 \text { and } 52 \text { discontinued in fluconazole and placebo groups respectively with reasons giv- } \\
\text { en. }\end{array}$ \\
\hline Interventions & $\begin{array}{l}2 \text { groups control = placebo versus fluconazole (100 mg) once daily from sixth to last session of ra- } \\
\text { diotherapy . Duration: maximum of } 56 \text { days. }\end{array}$ \\
\hline Outcomes & $\begin{array}{l}\text { Mycologic assessment of oral cavity every } 2 \text { weeks and at end by direct microscopic evaluation and } \\
\text { culture for search of Candida. } \\
\text { Other outcomes: days to outbreak (Kaplan Meier survival curve). RTOG acute toxicity score, adverse } \\
\text { events. }\end{array}$
\end{tabular}

\section{Notes}

\section{Elad 2006}

$\begin{array}{ll}\text { Methods } & \begin{array}{l}\text { Randomised, parallel group study conducted in Israel. Patient and provider not blinded; unclear if } \\ \text { assessor blinded. Clear information on withdrawals. Dentist not involved in the study. }\end{array}\end{array}$


Elad 2006 (Continued)

Participants Adults with mixed cancer. 20 patients enrolled and completed.

\begin{tabular}{ll}
\hline Interventions & $\begin{array}{l}2 \text { groups chlorhexidine (0.2\% mouthrinse x4/day) versus chlorhexidine (0.2\% mouthrinse x4/day) } \\
\text { with amphotericin B ( } 10 \mathrm{mg} \text { lozenges } x 4 / \text { day). Duration: } 7 \text { days prior to HSCT until discharge from } \\
\text { hospital (on average about } 50 \text { days). }\end{array}$ \\
\hline Outcomes & $\begin{array}{l}\text { Clinical assessment of oral candidiasis twice weekly basis from day - } 7 \text { until one month after dis- } \\
\text { charge. } \\
\text { Other outcomes: hospitalisation, medication. }\end{array}$ \\
\hline
\end{tabular}

Notes

RTOG = Radiation Therapy Oncology Group

$\mathrm{HSCT}=$ hematopoietic stem cell transplantation

\section{DATA AND ANALYSES}

\section{Comparison 1. Comparisons with placebo/no treatment for all drug types}

\begin{tabular}{|c|c|c|c|c|}
\hline Outcome or subgroup title & $\begin{array}{l}\text { No. of } \\
\text { studies }\end{array}$ & $\begin{array}{l}\text { No. of } \\
\text { partici- } \\
\text { pants }\end{array}$ & Statistical method & Effect size \\
\hline 1 Oral candidiasis present & 18 & & Risk Ratio (M-H, Random, 95\% Cl) & Subtotals only \\
\hline $\begin{array}{l}1.1 \text { drugs absorbed from } \mathrm{Gl} \\
\text { tract }\end{array}$ & 7 & 1153 & Risk Ratio (M-H, Random, 95\% Cl) & $0.47[0.29,0.78]$ \\
\hline $\begin{array}{l}1.2 \text { drugs partially absorbed } \\
\text { from GI tract }\end{array}$ & 4 & 292 & Risk Ratio (M-H, Random, 95\% Cl) & $0.16[0.06,0.46]$ \\
\hline $\begin{array}{l}1.3 \text { drugs not absorbed from } \\
\text { GI tract }\end{array}$ & 8 & 382 & Risk Ratio $(\mathrm{M}-\mathrm{H}$, Random, 95\% Cl) & $0.69[0.47,1.01]$ \\
\hline 2 Systemic fungal infection & 8 & & Risk Ratio (M-H, Random, 95\% Cl) & Subtotals only \\
\hline $\begin{array}{l}2.1 \text { drugs absorbed from } \mathrm{Gl} \\
\text { tract }\end{array}$ & 6 & 1041 & Risk Ratio (M-H, Random, 95\% Cl) & $0.65[0.37,1.14]$ \\
\hline $\begin{array}{l}2.2 \text { drugs partially absorbed } \\
\text { from GI tract }\end{array}$ & 1 & 32 & Risk Ratio (M-H, Random, 95\% Cl) & $2.27[0.23,22.56]$ \\
\hline $\begin{array}{l}2.3 \text { drugs not absorbed from } \\
\text { GI tract }\end{array}$ & 2 & 71 & Risk Ratio (M-H, Random, 95\% Cl) & $0.10[0.01,1.75]$ \\
\hline 3 Death & 4 & & Risk Ratio (M-H, Random, 95\% Cl) & Subtotals only \\
\hline $\begin{array}{l}3.1 \text { drugs absorbed from } \mathrm{Gl} \\
\text { tract }\end{array}$ & 3 & 718 & Risk Ratio $(\mathrm{M}-\mathrm{H}$, Random, $95 \% \mathrm{Cl})$ & $1.44[0.14,15.43]$ \\
\hline $\begin{array}{l}3.2 \text { drugs partially absorbed } \\
\text { from GI tract }\end{array}$ & 0 & 0 & Risk Ratio (M-H, Random, 95\% Cl) & $0.0[0.0,0.0]$ \\
\hline
\end{tabular}




\begin{tabular}{|c|c|c|c|c|}
\hline Outcome or subgroup title & $\begin{array}{l}\text { No. of } \\
\text { studies }\end{array}$ & $\begin{array}{l}\text { No. of } \\
\text { partici- } \\
\text { pants }\end{array}$ & Statistical method & Effect size \\
\hline $\begin{array}{l}3.3 \text { drugs not absorbed from } \\
\text { GI tract }\end{array}$ & 1 & 51 & Risk Ratio (M-H, Random, 95\% Cl) & $0.16[0.01,2.95]$ \\
\hline $\begin{array}{l}4 \text { Empirical antifungal treat- } \\
\text { ment }\end{array}$ & 3 & & Risk Ratio (M-H, Random, 95\% Cl) & Subtotals only \\
\hline $\begin{array}{l}4.1 \text { drugs absorbed from } \mathrm{Gl} \\
\text { tract }\end{array}$ & 2 & 465 & Risk Ratio (M-H, Random, 95\% Cl) & $0.85[0.73,0.99]$ \\
\hline $\begin{array}{l}4.2 \text { drugs partially absorbed } \\
\text { for GI tract }\end{array}$ & 1 & 32 & Risk Ratio (M-H, Random, 95\% Cl) & $3.38[0.15,77.12]$ \\
\hline $\begin{array}{l}4.3 \text { drugs not absorbed from } \\
\text { GI tract }\end{array}$ & 0 & 0 & Risk Ratio (M-H, Random, 95\% Cl) & $0.0[0.0,0.0]$ \\
\hline $\begin{array}{l}5 \text { Toxicity (adverse events } \\
\text { 'probably due to drug') }\end{array}$ & 5 & & Risk Ratio (M-H, Random, 95\% Cl) & Subtotals only \\
\hline $\begin{array}{l}5.1 \text { drugs absorbed from } \mathrm{Gl} \\
\text { tract }\end{array}$ & 3 & 871 & Risk Ratio (M-H, Random, 95\% Cl) & $1.18[0.84,1.67]$ \\
\hline $\begin{array}{l}5.2 \text { drugs partially absorbed } \\
\text { from GI tract }\end{array}$ & 2 & 60 & Risk Ratio (M-H, Random, 95\% Cl) & $0.0[0.0,0.0]$ \\
\hline $\begin{array}{l}5.3 \text { drugs not absorbed from } \\
\text { GI tract }\end{array}$ & 0 & 0 & Risk Ratio (M-H, Random, 95\% Cl) & $0.0[0.0,0.0]$ \\
\hline 6 Good compliance & 2 & & Risk Ratio (M-H, Random, 95\% Cl) & Subtotals only \\
\hline $\begin{array}{l}6.1 \text { drugs absorbed from } \mathrm{Gl} \\
\text { tract }\end{array}$ & 2 & 615 & Risk Ratio (M-H, Random, 95\% Cl) & $1.06[0.89,1.27]$ \\
\hline
\end{tabular}

\section{Analysis 1.1. Comparison 1 Comparisons with placebo/no treatment for all drug types, Outcome 1 Oral candidiasis present.}

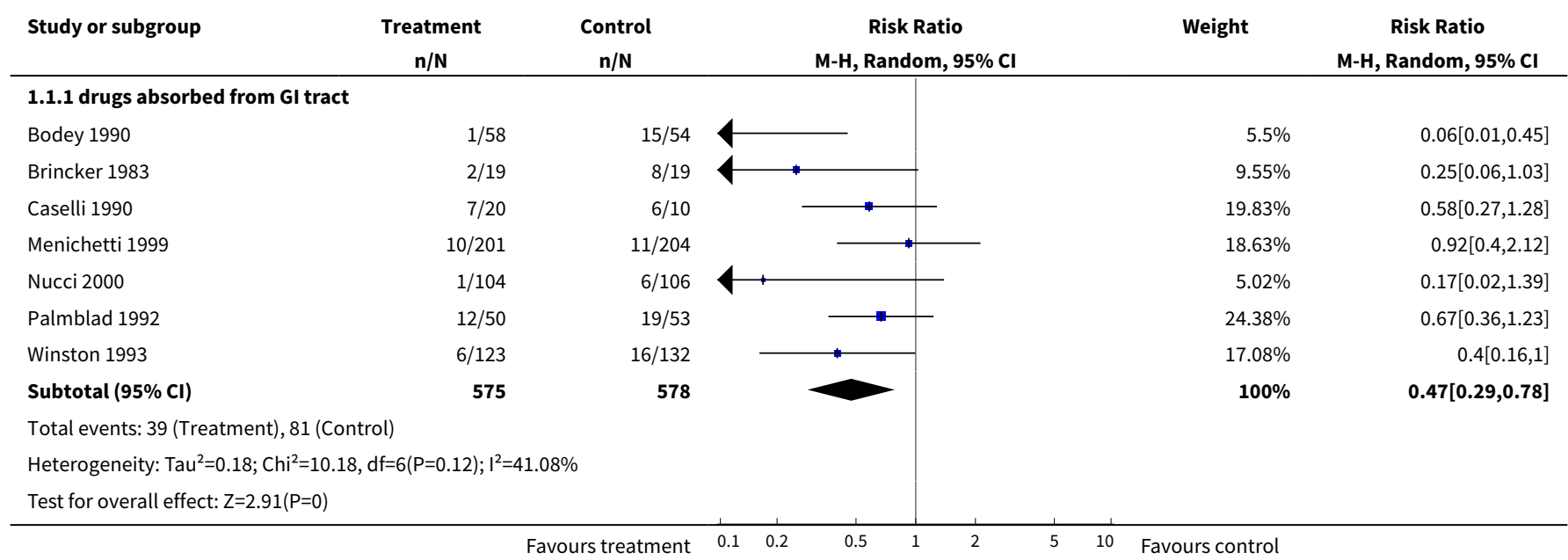




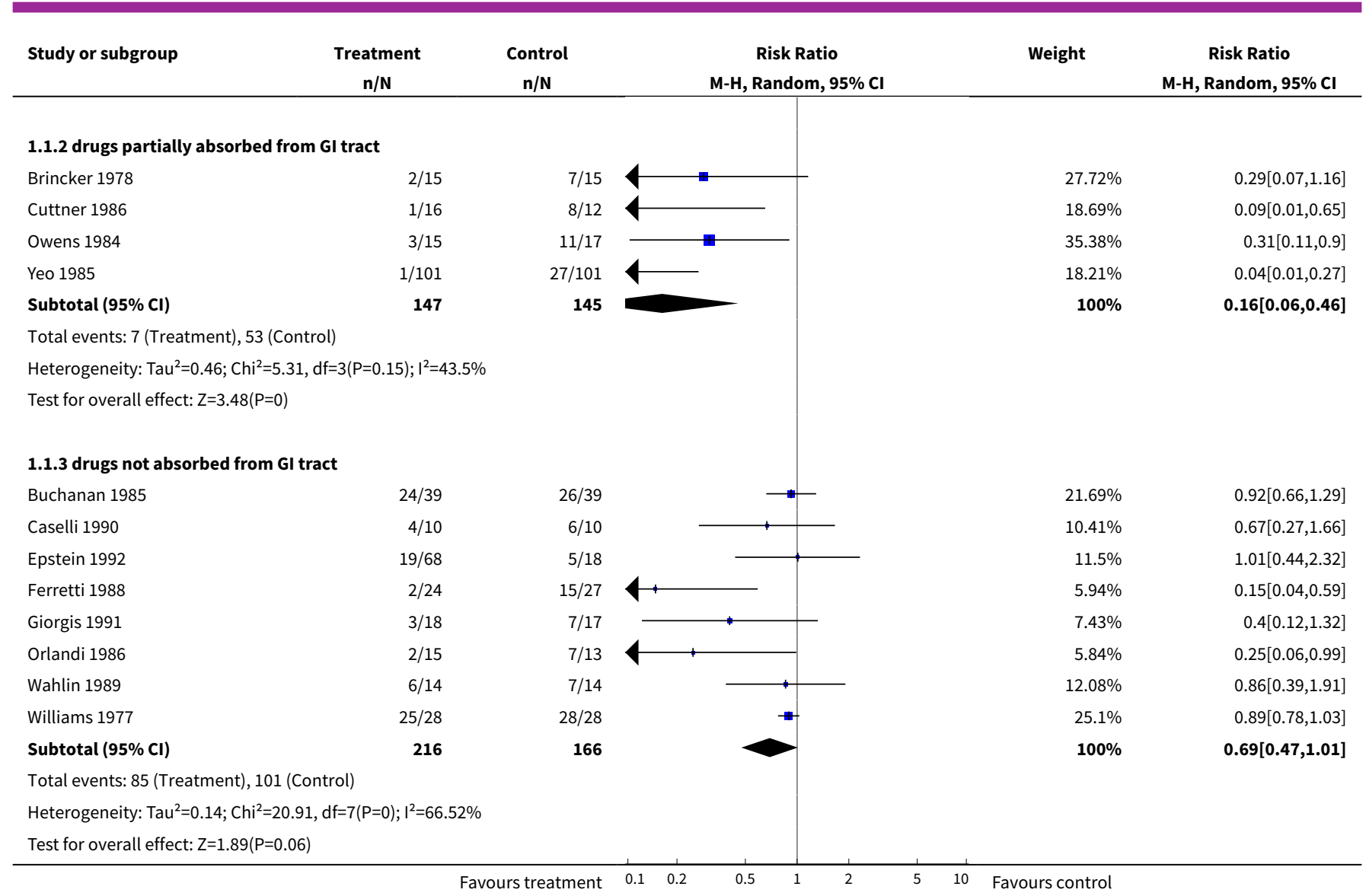

Analysis 1.2. Comparison 1 Comparisons with placebo/no treatment for all drug types, Outcome 2 Systemic fungal infection.

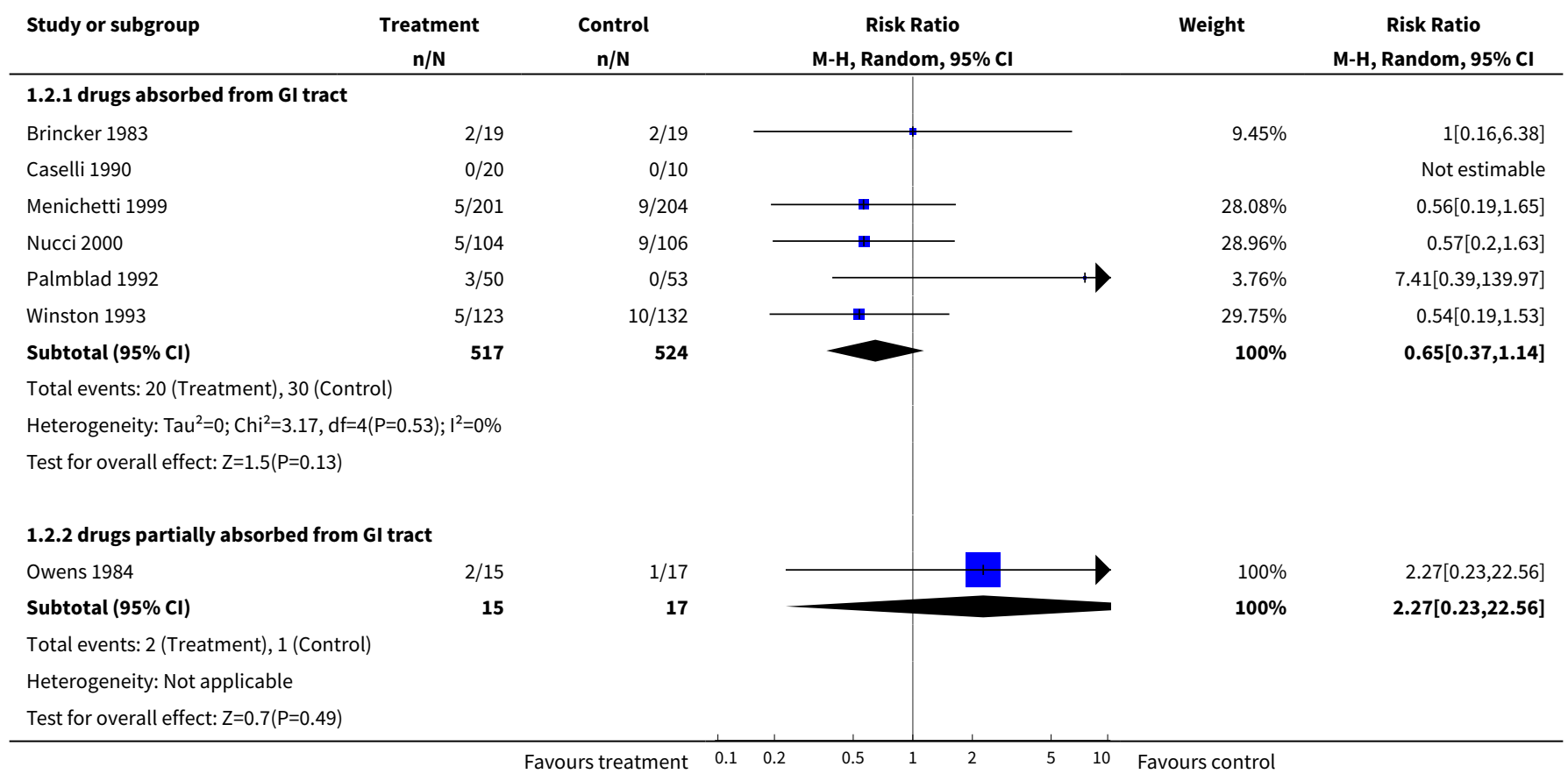




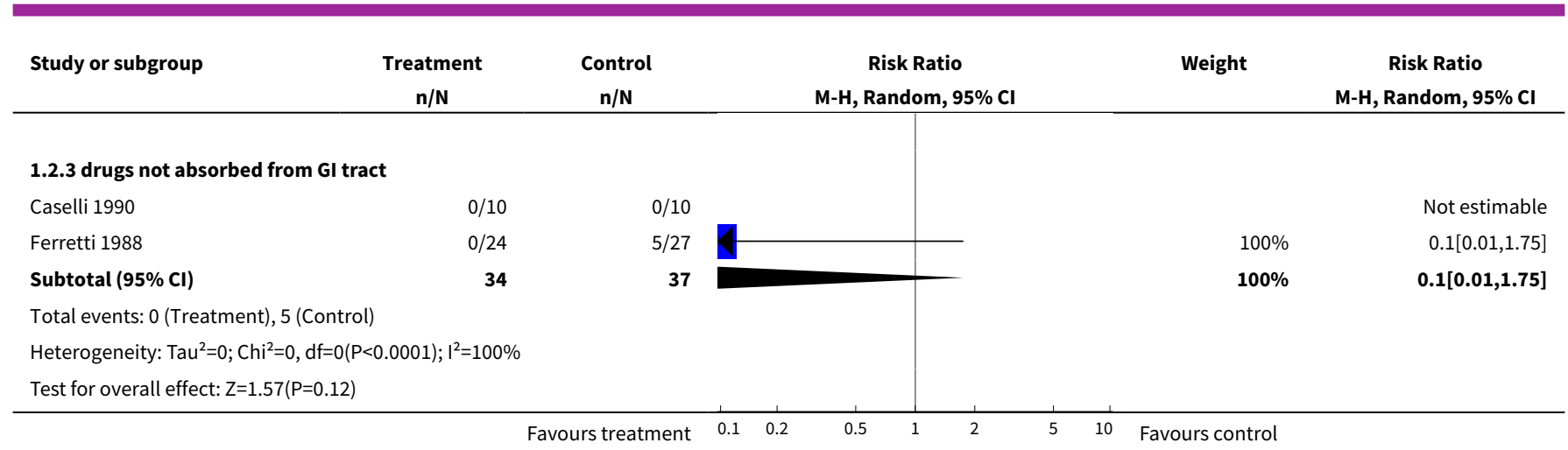

Analysis 1.3. Comparison 1 Comparisons with placebo/no treatment for all drug types, Outcome 3 Death.

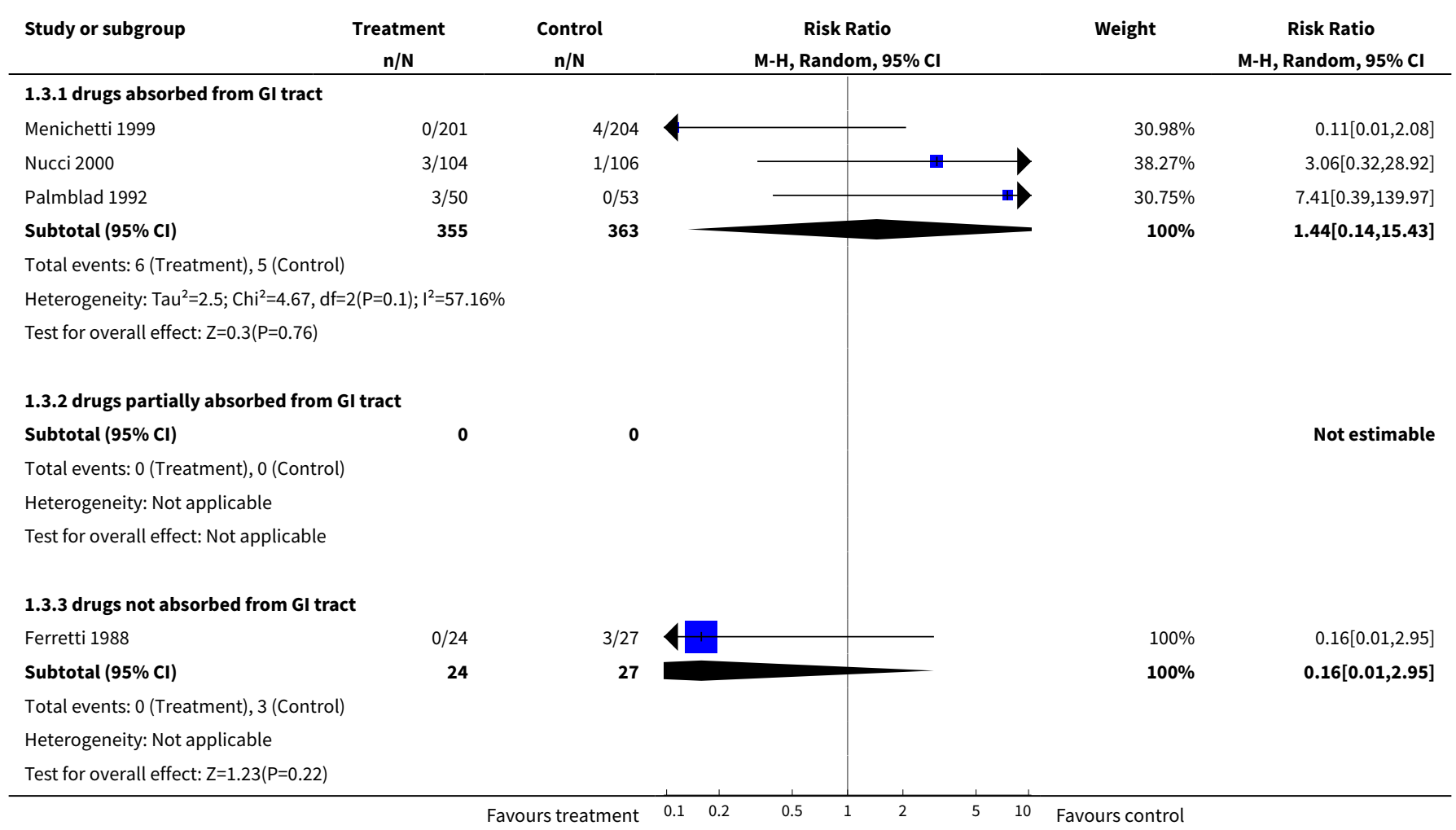

Analysis 1.4. Comparison 1 Comparisons with placebo/no treatment for all drug types, Outcome 4 Empirical antifungal treatment.

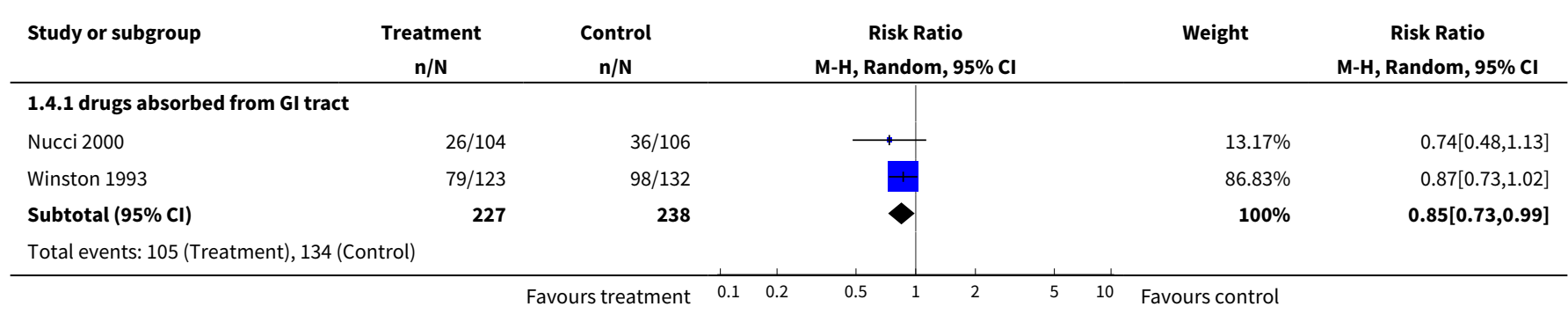




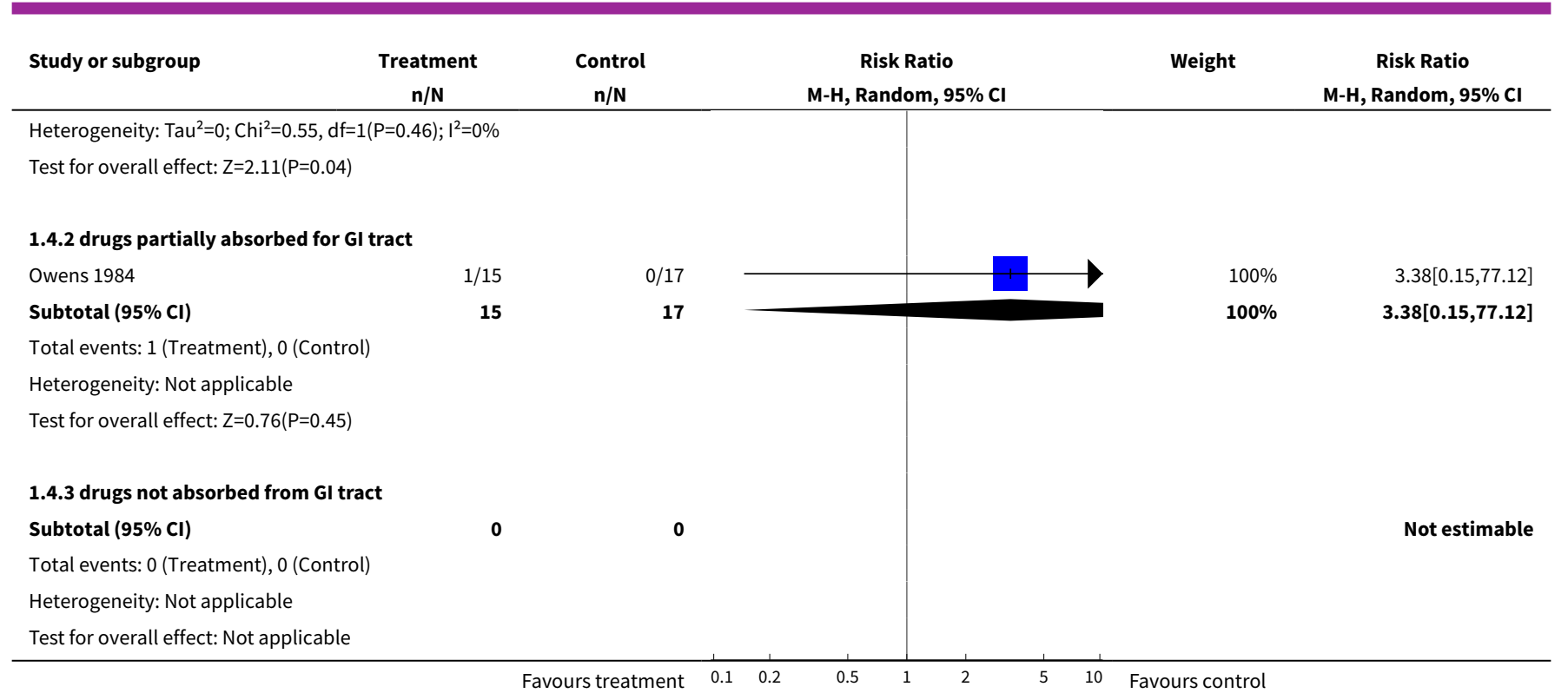

Analysis 1.5. Comparison 1 Comparisons with placebo/no treatment for all drug types, Outcome 5 Toxicity (adverse events 'probably due to drug').

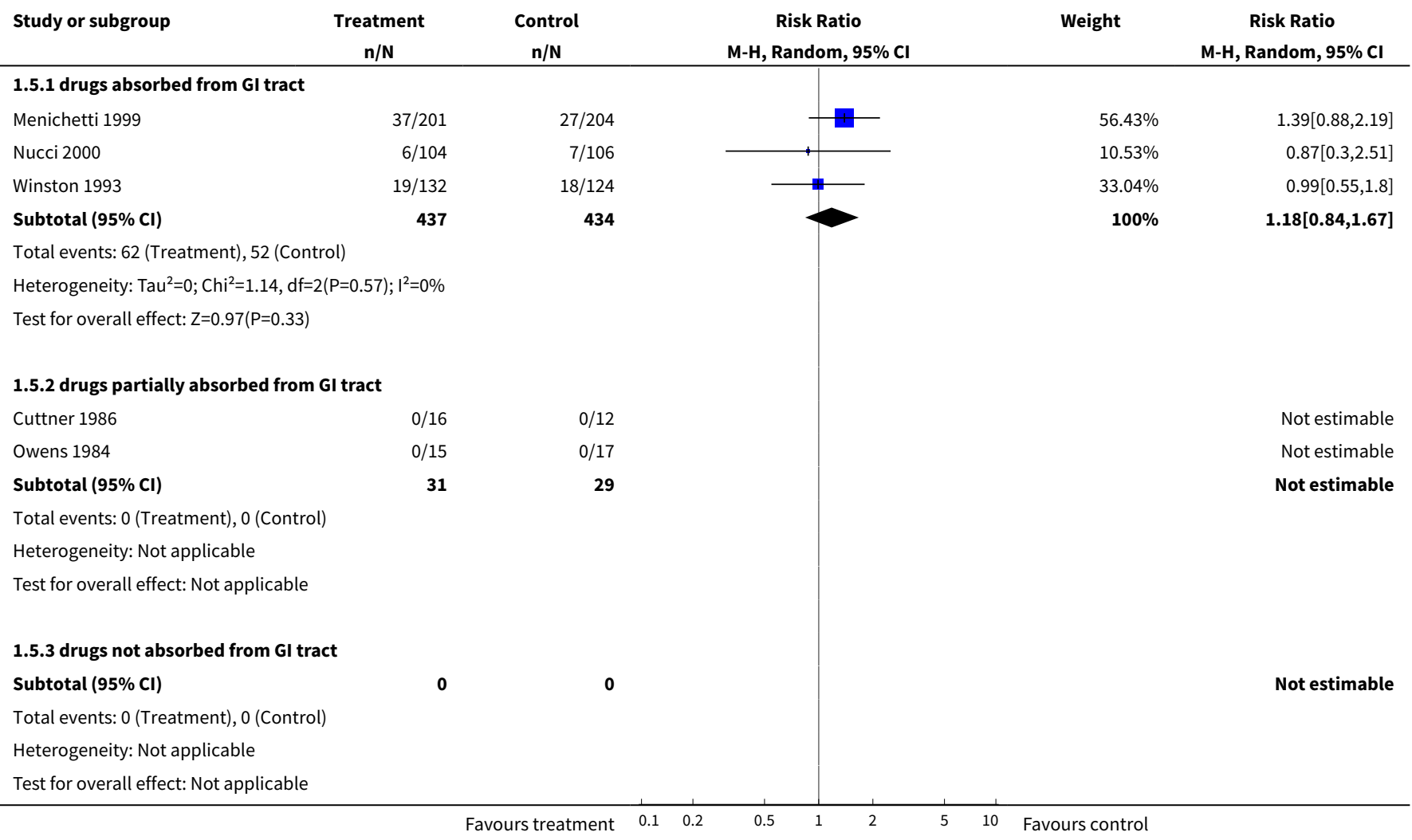


Analysis 1.6. Comparison 1 Comparisons with placebo/ no treatment for all drug types, Outcome 6 Good compliance.

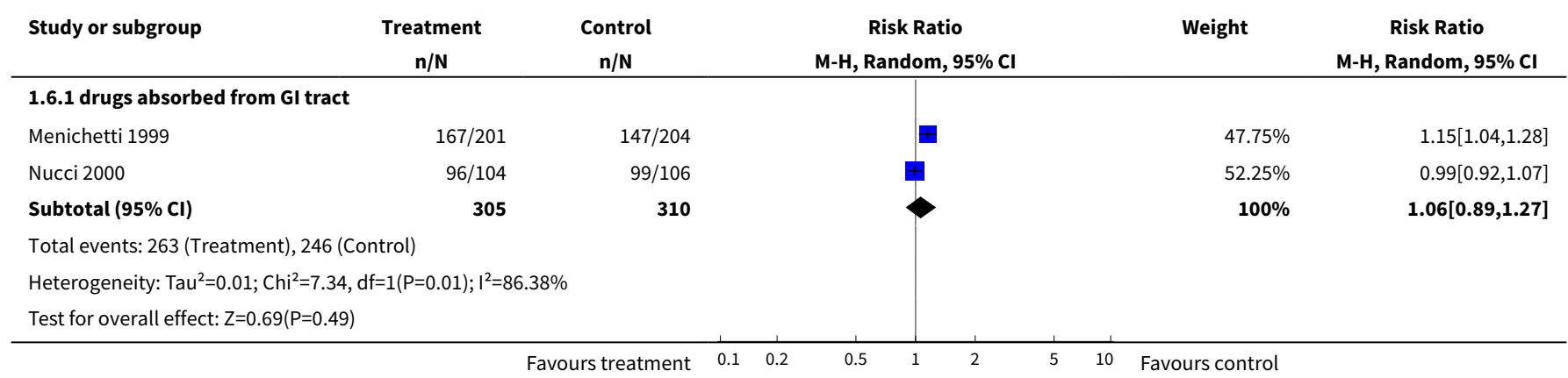

\section{Comparison 2. Comparisons between drugs absorbed from $\mathrm{Gl}$ tract and those not absorbed}

\begin{tabular}{llllll}
\hline Outcome or subgroup title & $\begin{array}{l}\text { No. of } \\
\text { studies }\end{array}$ & $\begin{array}{l}\text { No. of } \\
\text { partici- } \\
\text { pants }\end{array}$ & Statistical method & Effect size \\
\hline 1 Oral candidiasis present & 8 & 2103 & Risk Ratio (M-H, Random, 95\% Cl) & $0.40[0.21,0.76]$ \\
\hline 2 Systemic fungal infection & 8 & 2103 & Risk Ratio (M-H, Random, 95\% Cl) & $0.59[0.33,1.06]$ \\
\hline 3 Death & 3 & 981 & Risk Ratio (M-H, Random, 95\% Cl) & $1.25[0.38,4.13]$ \\
\hline 4 Empirical antifungal treatment & 4 & 1031 & Risk Ratio (M-H, Random, 95\% Cl) & $0.89[0.68,1.16]$ \\
\hline $\begin{array}{l}\text { 5 Toxicity (adverse events 'probably due } \\
\text { to drug') }\end{array}$ & 6 & 2018 & Risk Ratio (M-H, Random, 95\% Cl) & $0.88[0.33,2.30]$ \\
\hline 6 Good compliance & 1 & 820 & Risk Ratio (M-H, Random, 95\% Cl) & $1.05[1.03,1.08]$ \\
\hline
\end{tabular}

\section{Analysis 2.1. Comparison 2 Comparisons between drugs absorbed from GI tract and those not absorbed, Outcome 1 Oral candidiasis present.}

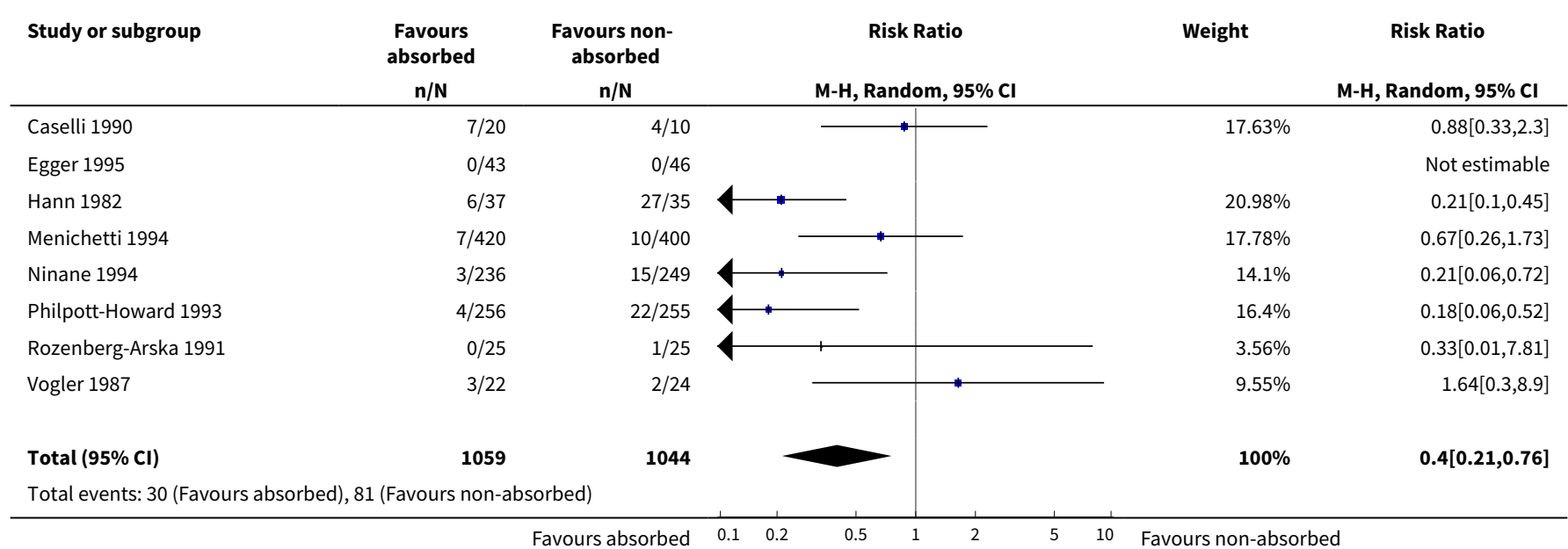




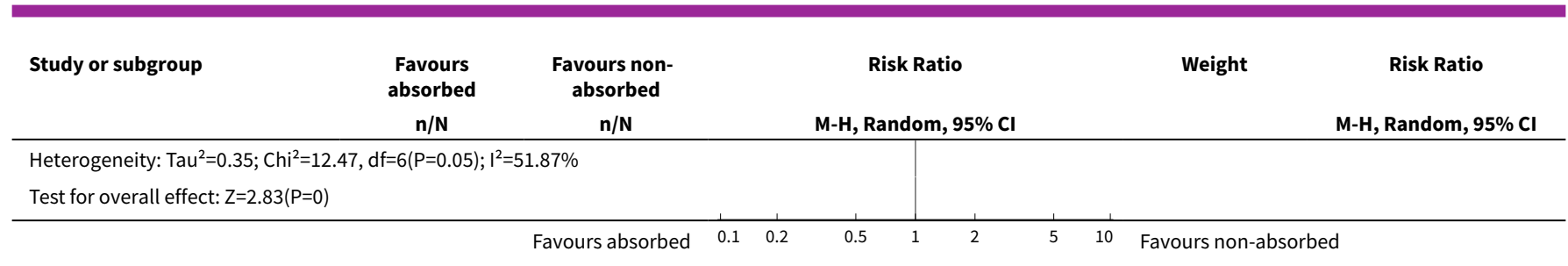

Analysis 2.2. Comparison 2 Comparisons between drugs absorbed from GI tract and those not absorbed, Outcome 2 Systemic fungal infection.

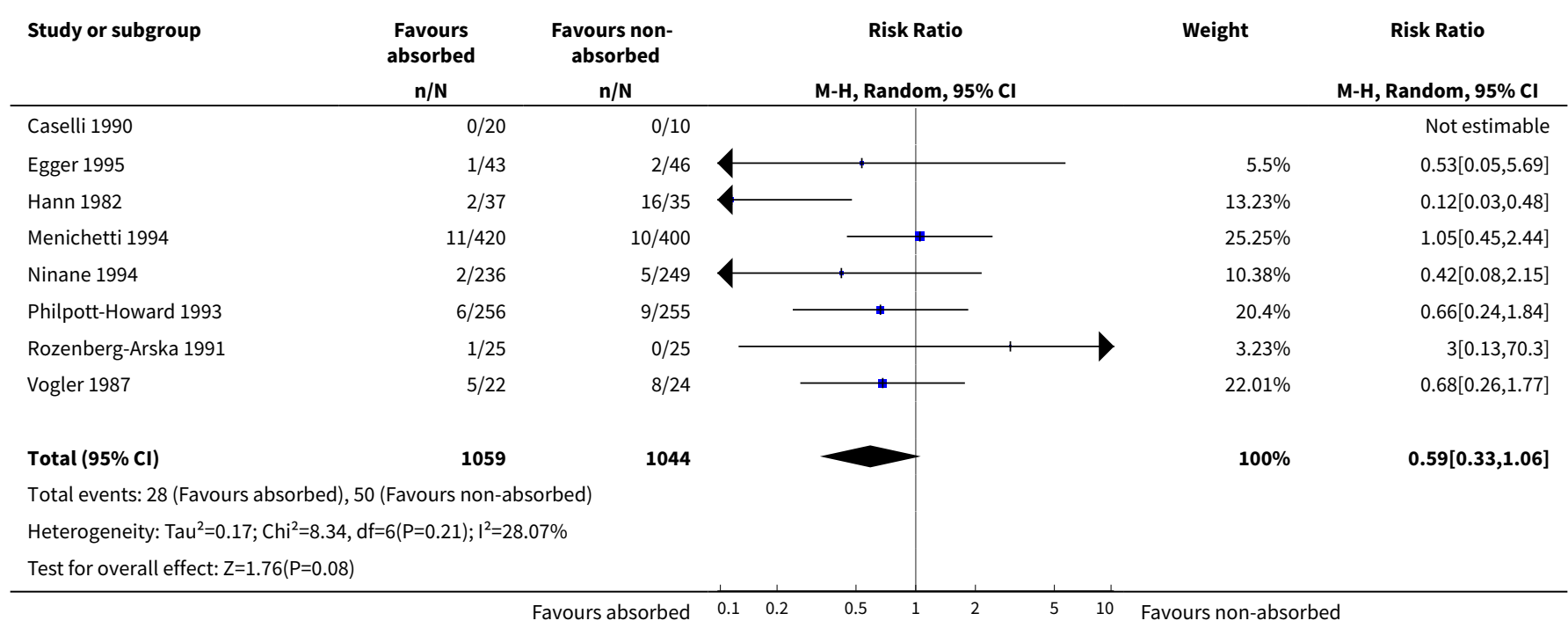

Analysis 2.3. Comparison 2 Comparisons between drugs absorbed from $\mathrm{GI}$ tract and those not absorbed, Outcome 3 Death.

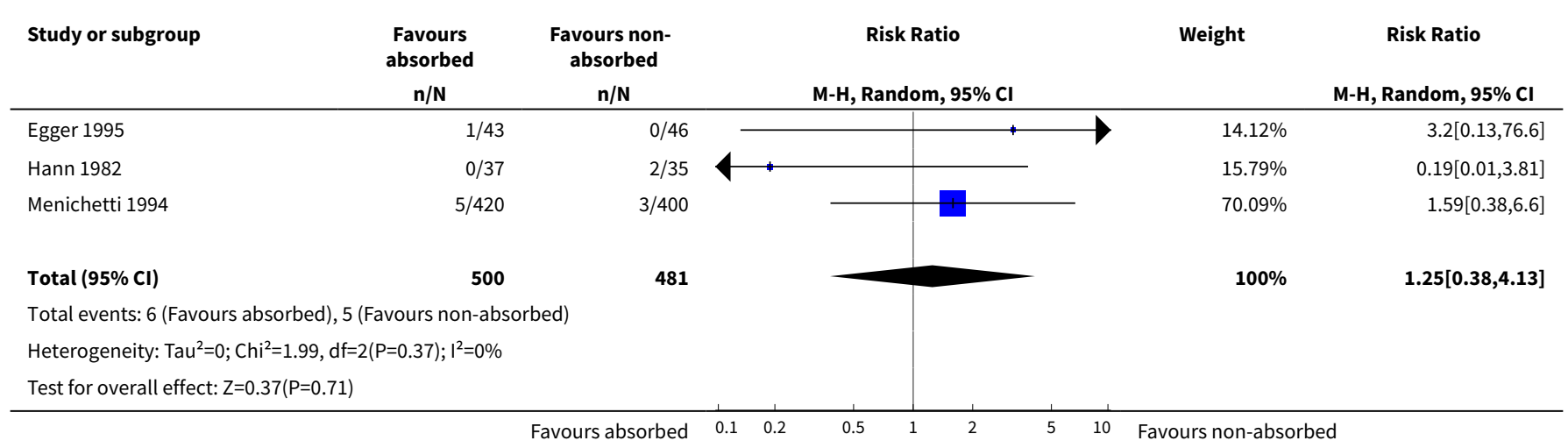


Analysis 2.4. Comparison 2 Comparisons between drugs absorbed from $\mathrm{GI}$ tract and those not absorbed, Outcome 4 Empirical antifungal treatment.

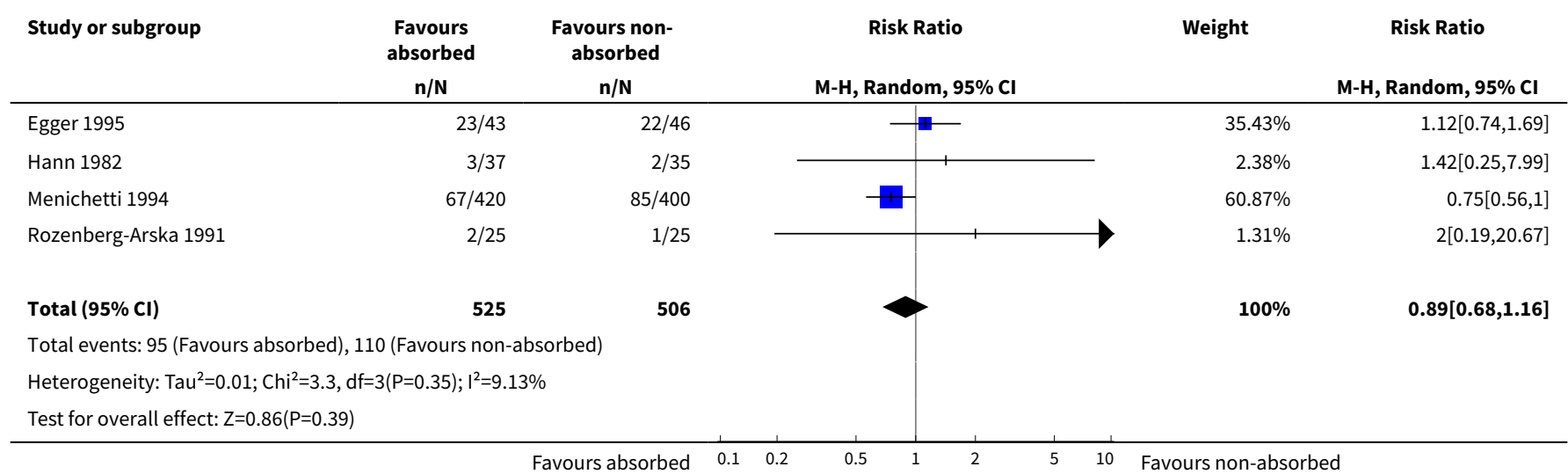

\section{Analysis 2.5. Comparison 2 Comparisons between drugs absorbed from $\mathrm{Gl}$ tract and} those not absorbed, Outcome 5 Toxicity (adverse events 'probably due to drug').

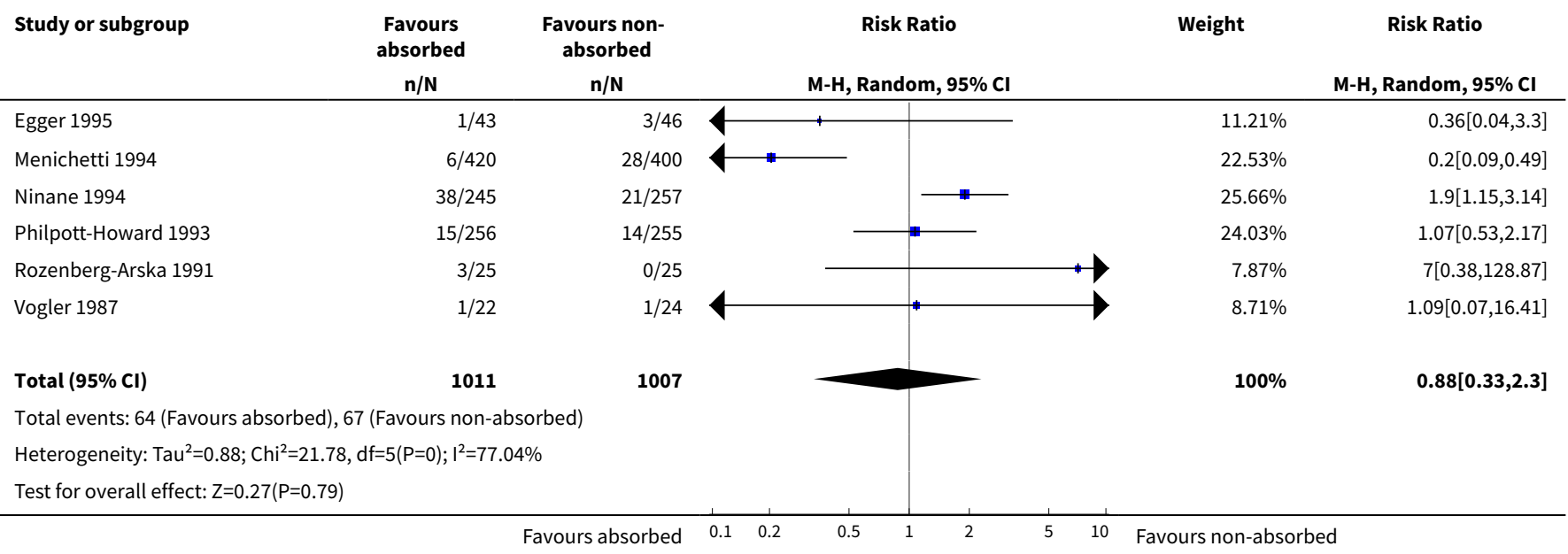

Analysis 2.6. Comparison 2 Comparisons between drugs absorbed from GI tract and those not absorbed, Outcome 6 Good compliance.

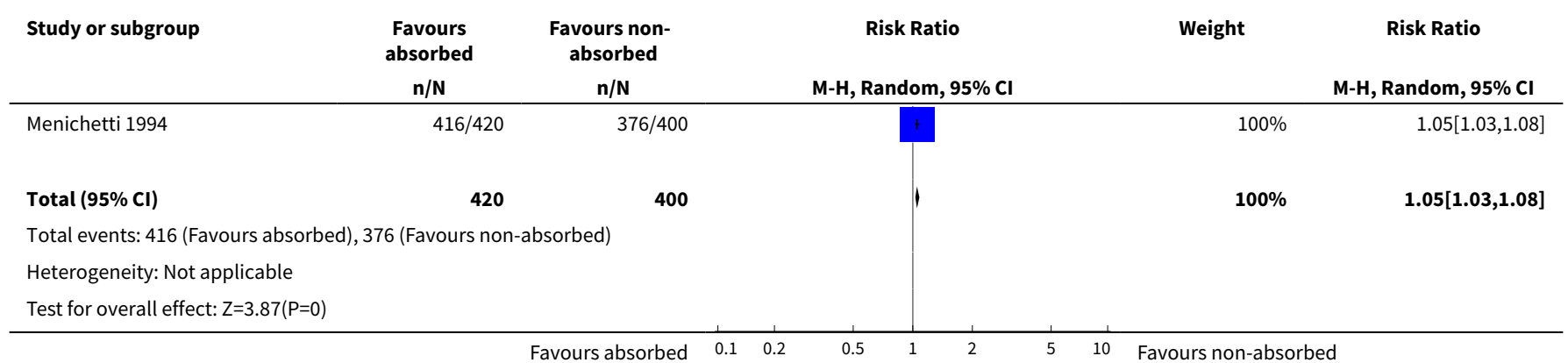


Comparison 3. Comparison of drugs absorbed from the GI tract

\begin{tabular}{|c|c|c|c|c|}
\hline Outcome or subgroup title & $\begin{array}{l}\text { No. of } \\
\text { studies }\end{array}$ & $\begin{array}{l}\text { No. of } \\
\text { partici- } \\
\text { pants }\end{array}$ & Statistical method & Effect size \\
\hline 1 Oral candidiasis present & 3 & & Risk Ratio (M-H, Random, 95\% Cl) & Totals not selected \\
\hline $\begin{array}{l}1.1 \text { Itraconazole versus flu- } \\
\text { conazole }\end{array}$ & 1 & & Risk Ratio (M-H, Random, 95\% Cl) & $0.0[0.0,0.0]$ \\
\hline $\begin{array}{l}1.2 \text { Ketoconazole versus } \\
\text { itraconazole }\end{array}$ & 1 & & Risk Ratio (M-H, Random, 95\% Cl) & $0.0[0.0,0.0]$ \\
\hline $\begin{array}{l}1.3 \text { Ketoconazole ( } 400 \mathrm{mg}) \\
\text { versus ketoconazole }(200 \\
\mathrm{mg})\end{array}$ & 1 & & Risk Ratio (M-H, Random, 95\% Cl) & $0.0[0.0,0.0]$ \\
\hline 2 Systemic fungal infection & 1 & & Risk Ratio (M-H, Random, 95\% Cl) & Totals not selected \\
\hline $\begin{array}{l}2.1 \text { Intraconazole versus flu- } \\
\text { conazole }\end{array}$ & 1 & & Risk Ratio (M-H, Random, 95\% Cl) & $0.0[0.0,0.0]$ \\
\hline 3 Death & 1 & & Risk Ratio (M-H, Random, 95\% Cl) & Totals not selected \\
\hline $\begin{array}{l}3.1 \text { Itraconazole versus flu- } \\
\text { conazole }\end{array}$ & 1 & & Risk Ratio (M-H, Random, 95\% Cl) & $0.0[0.0,0.0]$ \\
\hline $\begin{array}{l}4 \text { Empirical antifungal treat- } \\
\text { ment }\end{array}$ & 1 & & Risk Ratio (M-H, Random, 95\% Cl) & Totals not selected \\
\hline $\begin{array}{l}4.1 \text { Itraconazole versus flu- } \\
\text { conazole }\end{array}$ & 1 & & Risk Ratio (M-H, Random, 95\% Cl) & $0.0[0.0,0.0]$ \\
\hline $\begin{array}{l}5 \text { Toxicity (adverse events } \\
\text { 'probably due to drug') }\end{array}$ & 2 & & Risk Ratio (M-H, Random, 95\% Cl) & Totals not selected \\
\hline $\begin{array}{l}5.1 \text { Itraconazole versus flu- } \\
\text { conazole }\end{array}$ & 2 & & Risk Ratio (M-H, Random, 95\% Cl) & $0.0[0.0,0.0]$ \\
\hline 6 Good compliance & 1 & & Risk Ratio (M-H, Random, 95\% Cl) & Totals not selected \\
\hline $\begin{array}{l}6.1 \text { Itraconazole versus flu- } \\
\text { conazole }\end{array}$ & 1 & & Risk Ratio (M-H, Random, 95\% Cl) & $0.0[0.0,0.0]$ \\
\hline
\end{tabular}

Analysis 3.1. Comparison 3 Comparison of drugs absorbed from the GI tract, Outcome 1 Oral candidiasis present.

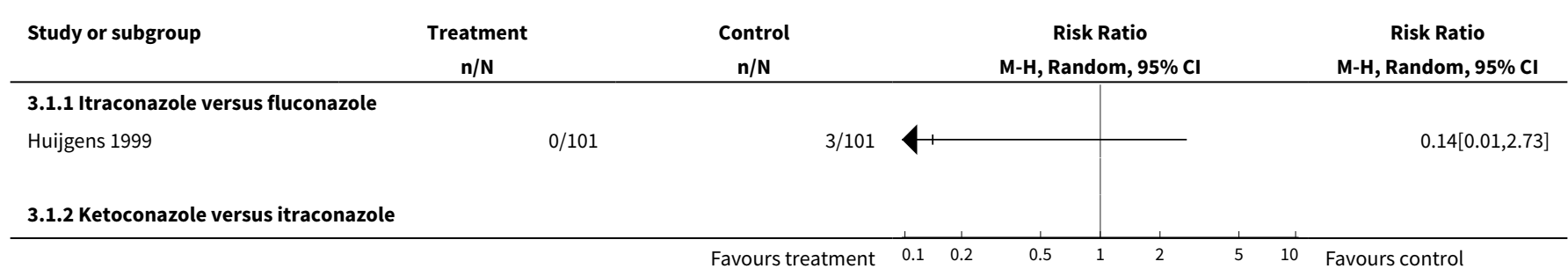




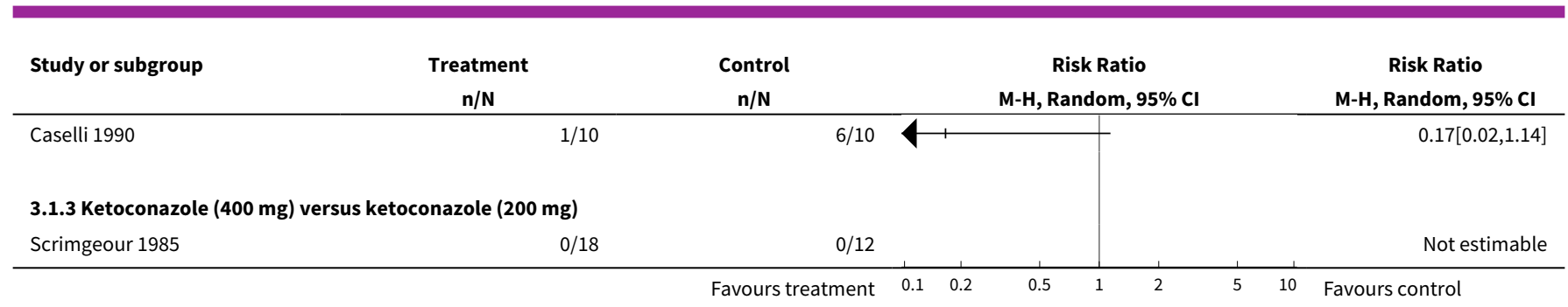

Analysis 3.2. Comparison 3 Comparison of drugs absorbed from the GI tract, Outcome 2 Systemic fungal infection.

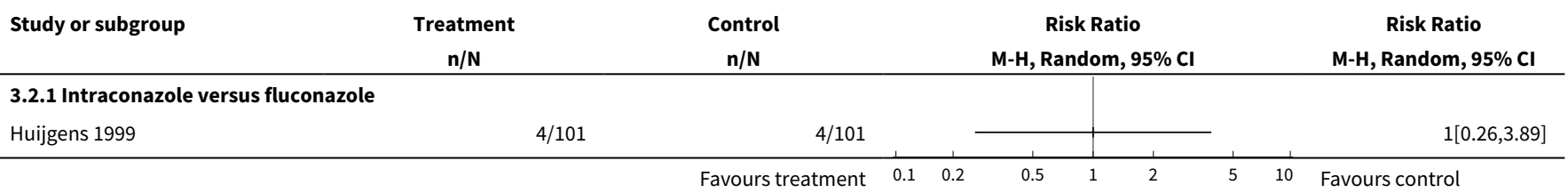

Analysis 3.3. Comparison 3 Comparison of drugs absorbed from the $\mathrm{GI}$ tract, Outcome 3 Death.

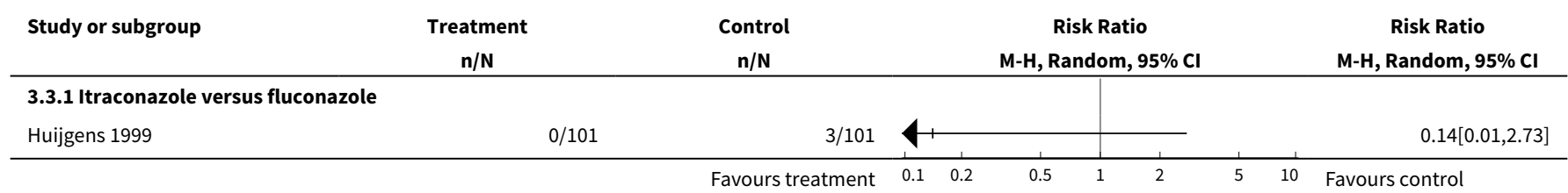

Analysis 3.4. Comparison 3 Comparison of drugs absorbed

from the GI tract, Outcome 4 Empirical antifungal treatment.

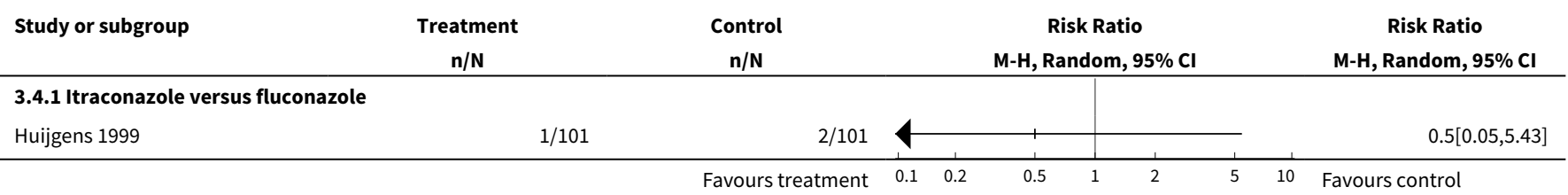

Analysis 3.5. Comparison 3 Comparison of drugs absorbed from the GI tract, Outcome 5 Toxicity (adverse events 'probably due to drug').

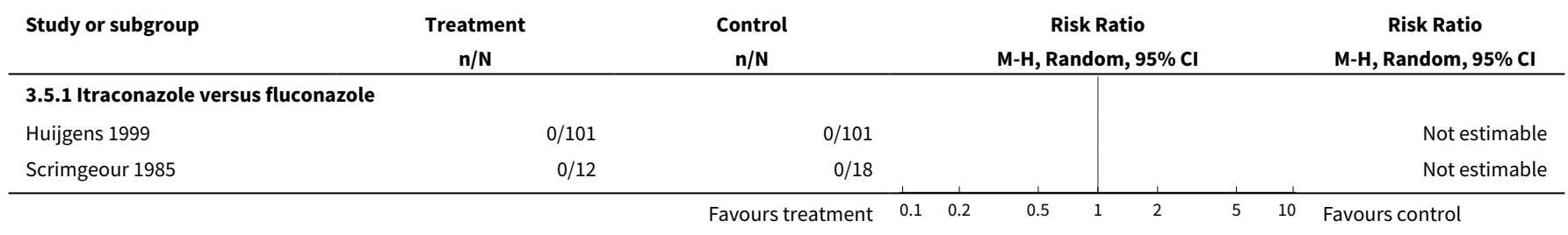


Analysis 3.6. Comparison 3 Comparison of drugs absorbed from the $\mathrm{Gl}$ tract, Outcome 6 Good compliance.

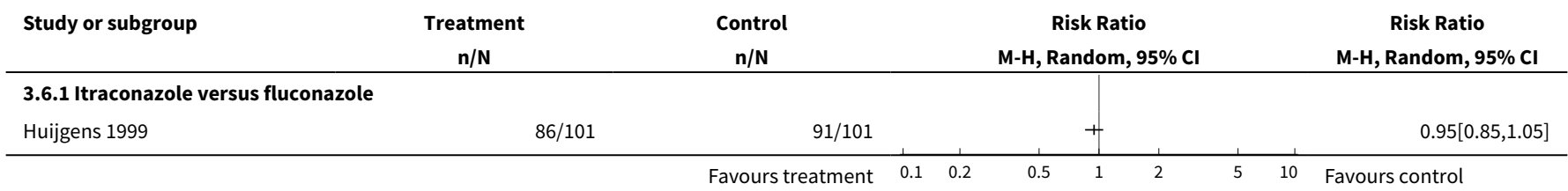

\section{Comparison 4. Comparison of drugs not absorbed from GI tract}

\begin{tabular}{|c|c|c|c|c|}
\hline Outcome or subgroup title & $\begin{array}{l}\text { No. of } \\
\text { studies }\end{array}$ & $\begin{array}{l}\text { No. of } \\
\text { partici- } \\
\text { pants }\end{array}$ & Statistical method & Effect size \\
\hline 1 Oral candidiasis present & 3 & & Risk Ratio (M-H, Random, 95\% Cl) & Subtotals only \\
\hline 1.1 Chlorhexidine versus nystatin & 1 & 34 & Risk Ratio (M-H, Random, 95\% Cl) & $0.89[0.36,2.21]$ \\
\hline $\begin{array}{l}1.2 \text { Chlorhexidine versus chlorhexi- } \\
\text { dine plus nystatin }\end{array}$ & 1 & 52 & Risk Ratio (M-H, Random, 95\% Cl) & $1.62[0.64,4.10]$ \\
\hline $\begin{array}{l}1.3 \text { Nystatin versus chlorhexidine plus } \\
\text { nystatin }\end{array}$ & 1 & 50 & Risk Ratio (M-H, Random, 95\% Cl) & $1.82[0.73,4.54]$ \\
\hline 1.4 Nystatin versus natamycin & 1 & 28 & Risk Ratio (M-H, Random, 95\% Cl) & $1.07[0.83,1.37]$ \\
\hline $\begin{array}{l}\text { 1.5 Norfloxacin + amphotericin B ver- } \\
\text { sus amphotericin B }\end{array}$ & 1 & 106 & Risk Ratio (M-H, Random, 95\% Cl) & $0.38[0.15,1.00]$ \\
\hline
\end{tabular}

Analysis 4.1. Comparison 4 Comparison of drugs not absorbed from $\mathrm{Gl}$ tract, Outcome 1 Oral candidiasis present.

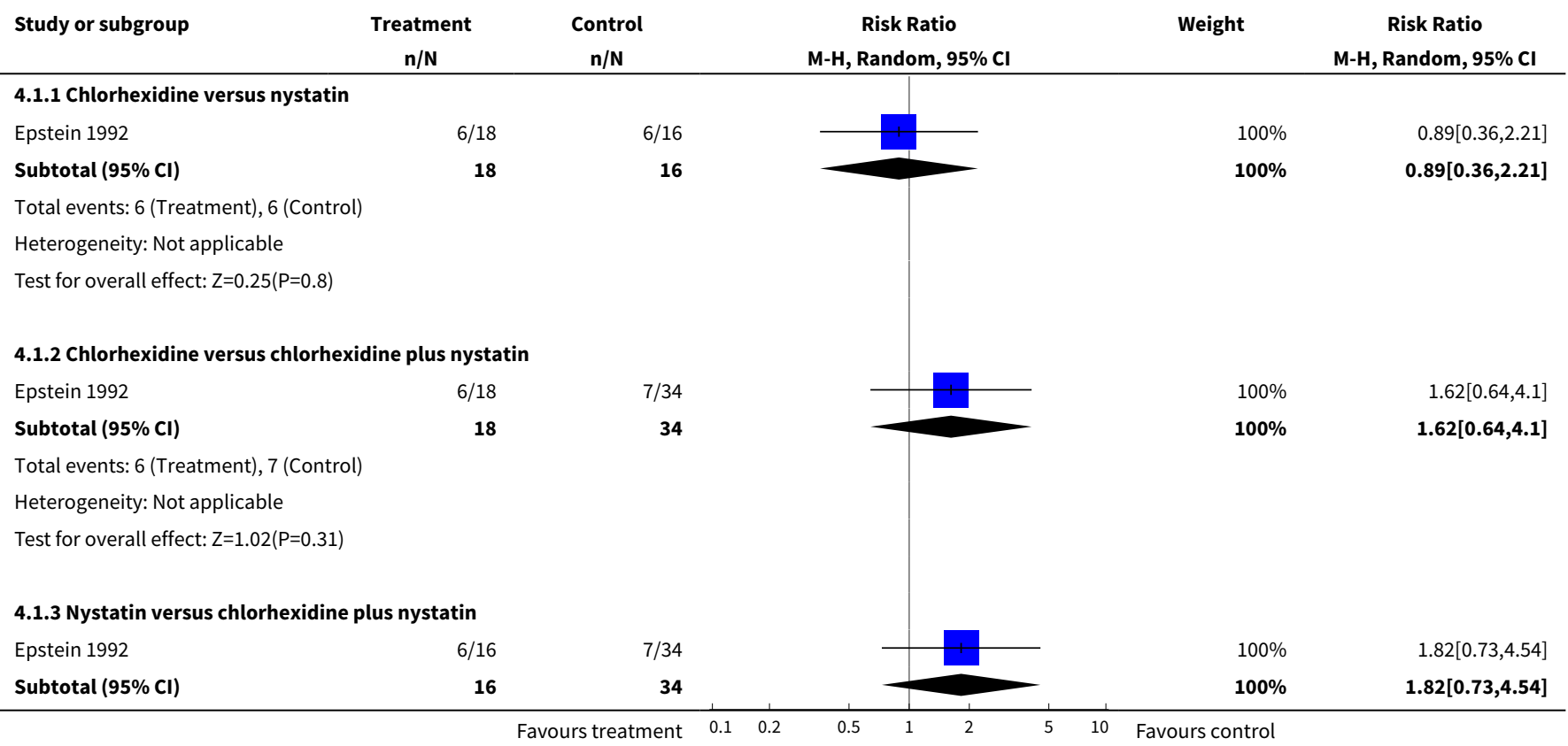




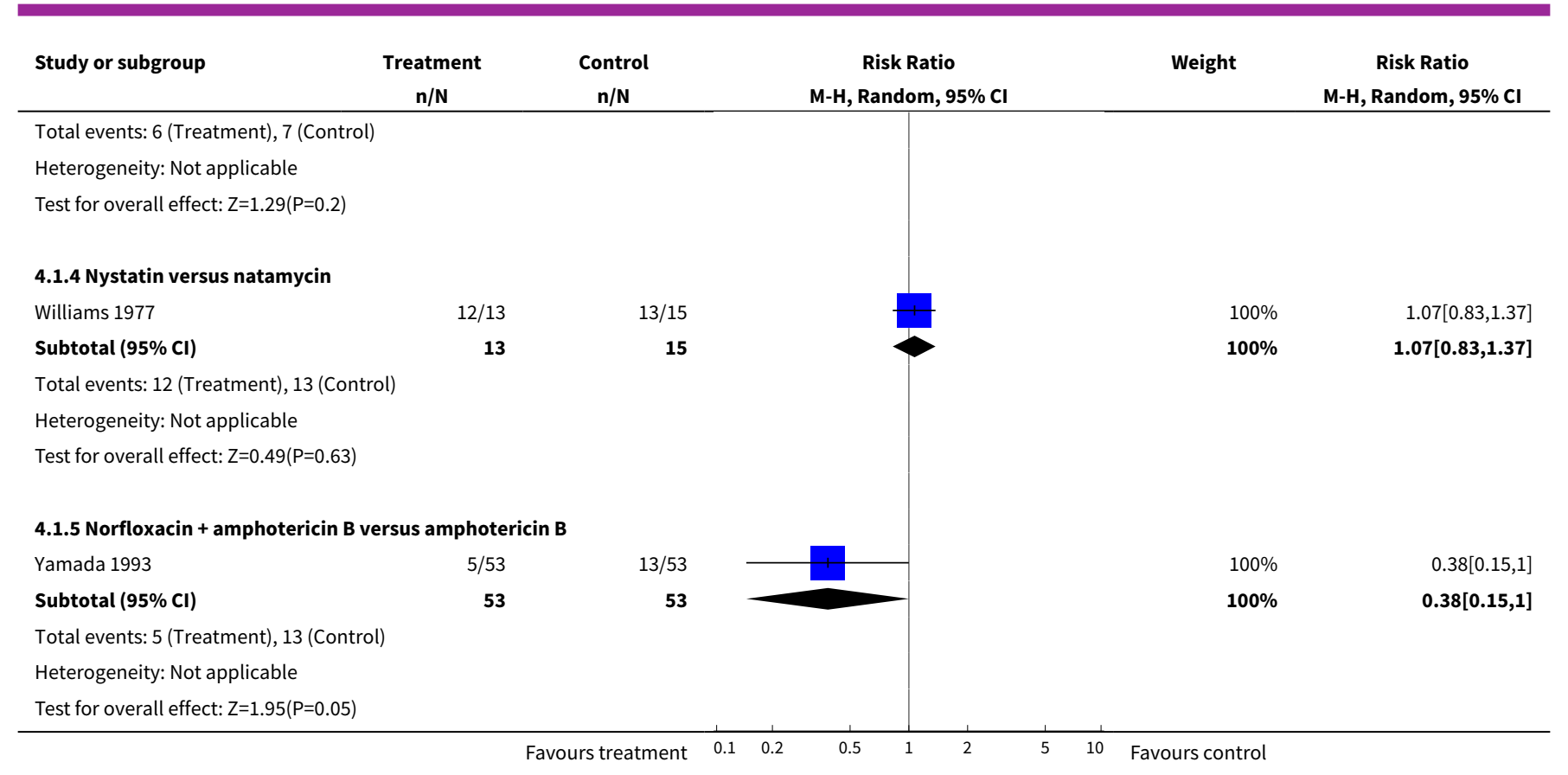

Comparison 5. Comparisons with placebo/no treatment for not absorbed drug types

\begin{tabular}{lllll}
\hline Outcome or subgroup title & $\begin{array}{l}\text { No. of } \\
\text { studies }\end{array}$ & $\begin{array}{l}\text { No. of } \\
\text { partici- } \\
\text { pants }\end{array}$ & Statistical method & Effect size \\
\hline 1 Oral candidiasis present & 8 & 351 & Risk Ratio $(\mathrm{M}-\mathrm{H}$, Random, 95\% Cl) & $0.76[0.54,1.07]$ \\
\hline 1.1 Nystatin & 3 & 153 & Risk Ratio $(\mathrm{M}-\mathrm{H}$, Random, 95\% Cl) & $0.92[0.78,1.08]$ \\
\hline 1.2 Amphotericin B & 2 & 48 & Risk Ratio (M-H, Random, 95\% Cl) & $0.46[0.18,1.23]$ \\
\hline 1.3 Chlorhexidine & 3 & 115 & Risk Ratio (M-H, Random, 95\% Cl) & $0.59[0.19,1.83]$ \\
\hline 1.4 Thymostimulin & 1 & 35 & Risk Ratio (M-H, Random, 95\% Cl) & $0.40[0.12,1.32]$ \\
\hline
\end{tabular}

\section{Analysis 5.1. Comparison 5 Comparisons with placebo/no treatment for not absorbed drug types, Outcome 1 Oral candidiasis present.}

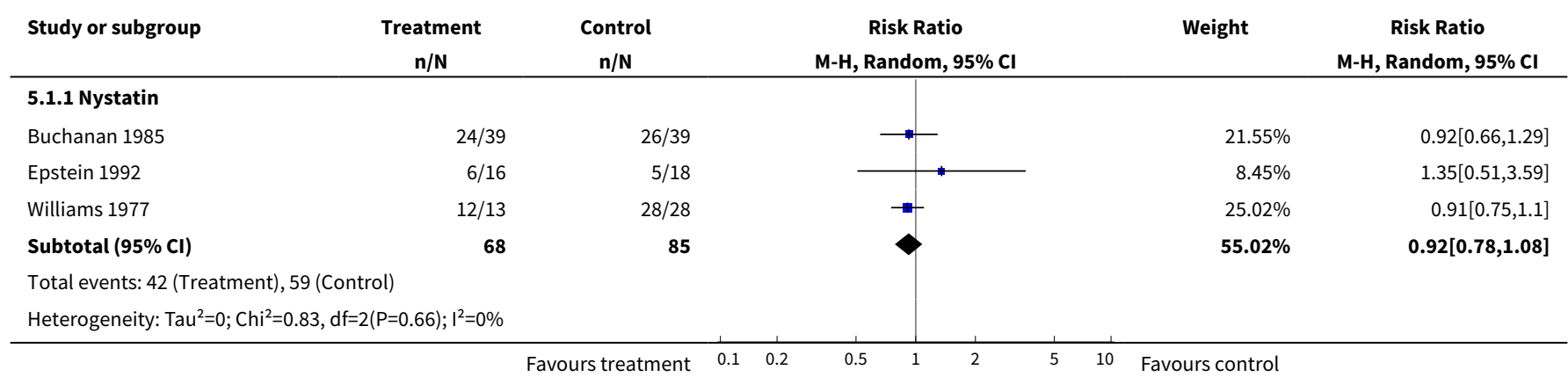




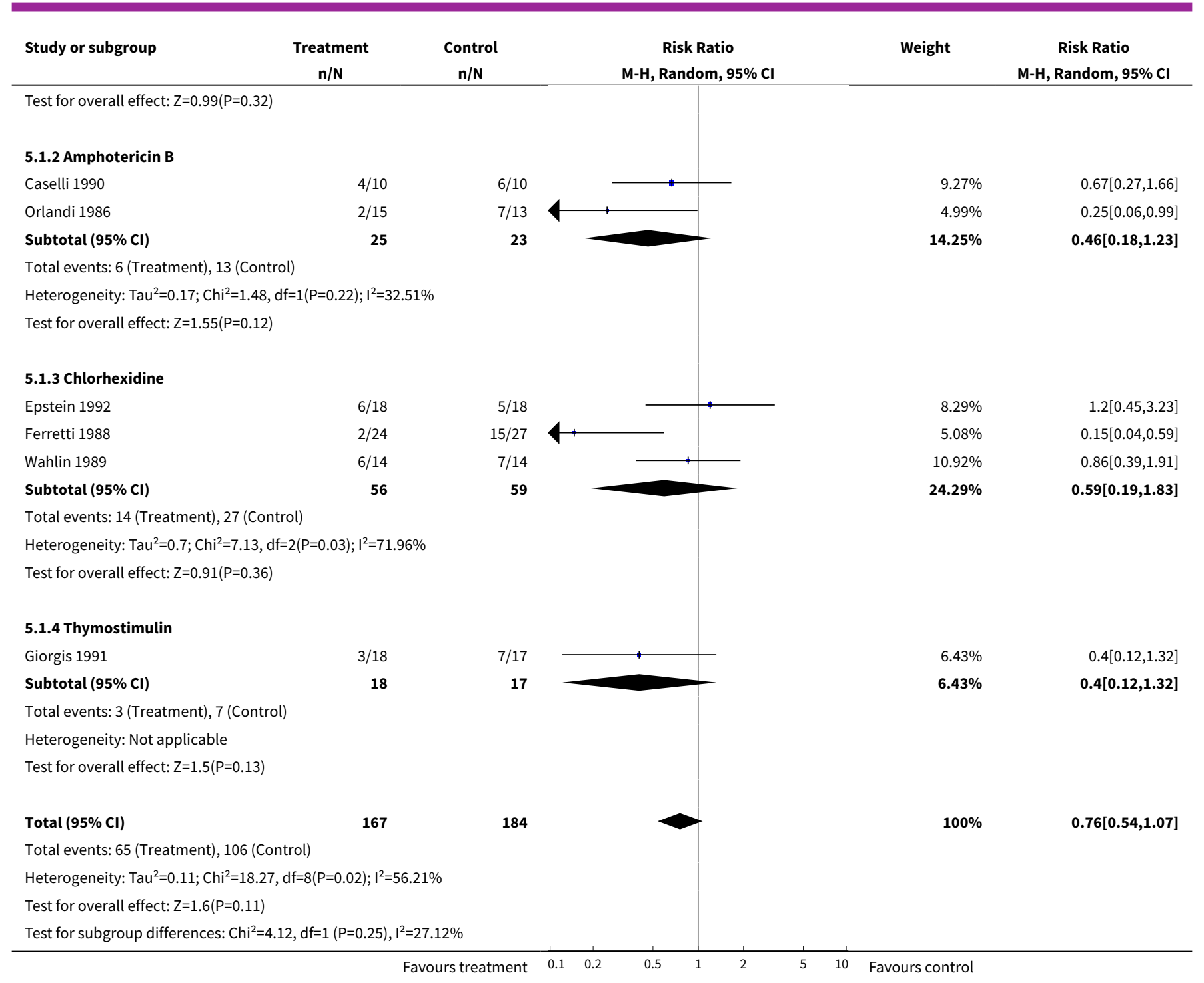

\section{ADDITIONAL TABLES}

Table 1. Quality assessment of included studies

\begin{tabular}{lllllll}
\hline Study & Concealed allocation & $\begin{array}{l}\text { Patient } \\
\text { blinded }\end{array}$ & $\begin{array}{l}\text { Provider } \\
\text { blinded }\end{array}$ & $\begin{array}{l}\text { Outcome } \\
\text { blinded }\end{array}$ & $\begin{array}{l}\text { Clear } \\
\text { with- } \\
\text { drawals }\end{array}$ & Risk of bias \\
\hline Bodey 1990 & adequate & yes & yes & yes & no & moderate \\
\hline Brincker 1978 & adequate & yes & yes & yes & yes & low \\
\hline Brincker 1983 & adequate & yes & yes & yes & yes & low \\
\hline Buchanan 1985 & unclear & no & no & unclear & yes & high \\
\hline Caselli 1990 & unclear & no & no & yes & yes & moderate
\end{tabular}


Table 1. Quality assessment of included studies (Continued)

\begin{tabular}{|c|c|c|c|c|c|c|}
\hline Cuttner 1986 & adequate & yes & yes & yes & yes & low \\
\hline Egger 1995 & unclear & no & no & unclear & no & high \\
\hline Epstein 1992 & adequate & no & no & unclear & no & high \\
\hline Ferretti 1988 & adequate & yes & yes & yes & no & moderate \\
\hline Giorgis 1991 & unclear & yes & no & no & yes & high \\
\hline Hann 1982 & unclear & no & no & yes & yes & moderate \\
\hline Huijgens 1999 & unclear & yes & yes & yes & no & high \\
\hline Menichetti 1994 & unclear & no & no & unclear & yes & high \\
\hline Menichetti 1999 & unclear & yes & yes & yes & yes & moderate \\
\hline Ninane 1994 & unclear & no & no & unclear & no & high \\
\hline Nucci 2000 & adequate & yes & yes & yes & yes & low \\
\hline Orlandi 1986 & unclear & no & no & unclear & yes & high \\
\hline Owens 1984 & adequate & yes & yes & yes & no & moderate \\
\hline Palmblad 1992 & unclear & yes & yes & yes & yes & moderate \\
\hline Philpott-Howard 1993 & unclear & no & no & unclear & yes & high \\
\hline Rozenberg-Arska 1991 & unclear & no & no & unclear & no & high \\
\hline Scrimgeour 1985 & unclear & unclear & unclear & unclear & no & high \\
\hline Vogler 1987 & unclear & no & no & unclear & yes & high \\
\hline Wahlin 1989 & adequate & no & no & yes & yes & low \\
\hline Williams 1977 & adequate & no & no & no & yes & moderate \\
\hline Winston 1993 & unclear & yes & yes & yes & yes & moderate \\
\hline Yamada 1993 & unclear & no & no & unclear & yes & high \\
\hline Yeo 1985 & adequate & no & no & yes & no & moderate \\
\hline
\end{tabular}

Table 2. Random-effects metaregression for placebo and no treatment controlled trials

Comparison $\quad \begin{aligned} & \text { Co-effi- } \\ & \text { cient }\end{aligned} \quad 95 \% \mathrm{Cl} \quad$ P value Interpretation


Table 2. Random-effects metaregression for placebo and no treatment controlled trials (Continued)

\begin{tabular}{lllll} 
Non-absorbed versus absorbed drugs & -0.47 & $-0.85,-0.09$ & 0.016 & $\begin{array}{l}\text { benefit (prevention of oral candidiasis) } \\
\text { greater for absorbed drugs }\end{array}$ \\
\hline $\begin{array}{l}\text { Non-absorbed versus partially absorbed } \\
\text { drugs }\end{array}$ & -1.23 & $-2.02,-0.45$ & 0.002 & benefit greater for partially absorbed drugs \\
\hline Mixed age versus adults & 0.16 & $-0.12,0.44$ & 0.27 & no significant difference \\
\hline Children versus adults & -0.01 & $-0.74,0.73$ & 0.98 & no significant difference \\
\hline Solid versus blood cancer & 1.12 & $0.10,2.14$ & 0.032 & $\begin{array}{l}\text { benefit greater for patients with blood can- } \\
\text { cer }\end{array}$ \\
\hline $\begin{array}{l}\text { Solid versus mixed cancer } \\
\text { Concealed allocation (yes versus no) }\end{array}$ & -0.05 & $-0.35,0.26$ & 0.77 & benefit greater for patients with mixed can- \\
\hline $\begin{array}{l}\text { Outcome assessment blinded (yes versus } \\
\text { no) }\end{array}$ & -0.34 & $-0.88,0.21$ & 0.23 & no significant difference \\
\hline
\end{tabular}

\section{APPENDICES}

\section{Appendix 1. Cochrane Oral Health Group Trials Register search strategy}

((neoplasm* OR leukemia OR leukaemia OR leukaemia OR lymphoma* OR plasmacytoma OR "histiocytosis malignant" OR reticuloendotheliosis OR "sarcoma mast cell" OR "Letterer Siwe disease" OR "immunoproliferative small intestine disease" OR "Hodgkin disease" OR "histiocytosis malignant" OR "bone marrow transplant" OR cancer* Or tumor* OR tumour* OR malignan* OR neutropeni* OR carcino* OR adenocarcinoma* OR radioth* OR radiat* OR radiochemo* OR irradiat* OR chemo*) AND (stomatitis OR "Stevens Johnson syndrome" OR "candidiasis oral" OR mucositis OR (oral AND (cand* OR mucos* OR fung*)) OR mycosis OR mycotic OR thrush))

\section{Appendix 2. CENTRAL search strategy}
1. EXP NEOPLASMS
2. ExP LEUKEMIA
3. Exp LYMPHOMA
4. Exp RADIOTHERAPY
5. EXP BONE MARROW TRANSPLANTATION
6. neoplasm ${ }^{\star}$ or cancer ${ }^{\star}$ or carcino* or malignan ${ }^{*}$
7. leukemi* or leukaemia*
8. tumour ${ }^{\star}$ or tumor ${ }^{\star}$
9. neutropeni ${ }^{\star}$
10. adenocarcinoma*
11. lymphoma*
12. (radioth* or radiat $^{*}$ or irradiat* ${ }^{\star}$ or radiochemo*)
13. (bone next marrow next transplant*) 
14. chemo* or radiochemo*

15. (\#1 or \#2 or \#3 or \#4 or \#5 or \#6 or \#7 or \#8 or \#9 or \#10 or \#11 or \#12 or \#13 or \#14)

16. Exp STOMATITIS

17. MUCOSITIS

18. CANDIDIASIS ORAL

19. stomatitis

20. (stevens next johnson next syndrome)

21. mucositis

22. oral near cand*

23. mouth near cand ${ }^{*}$

24. oral and fung*

25. mouth and fung*

26. (mycosis or mycotic or thrush)

27. \#16 or \#17 or \#18 or \#19 or \#20 or \#21 or \#22 or \#23 or \#24 or \#25 or \#26

28. \#15 AND \#27

\section{Appendix 3. MEDLINE via OVID search strategy}

11. exp NEOPLASMS/

2. $\exp$ LEUKEMIA/

3. $\operatorname{exp~LYMPHOMA/~}$

4. exp RADIOTHERAPY/

5. Bone Marrow Transplantation/

6. neoplasm\$.mp. [mp=title, abstract, subject headings, drug trade name, original title, device manufacturer, drug manufacturer name, device trade name]

7. cancer\$.mp. [mp=title, abstract, subject headings, drug trade name, original title, device manufacturer, drug manufacturer name, device trade name]

8. (leukaemi\$ or leukemi\$).mp. [mp=title, abstract, subject headings, drug trade name, original title, device manufacturer, drug manufacturer name, device trade name]

9. (tumour\$ or tumor\$).mp. [mp=title, abstract, subject headings, drug trade name, original title, device manufacturer, drug manufacturer name, device trade name]

10. malignan $\$ \mathrm{mp}$. [mp=title, abstract, subject headings, drug trade name, original title, device manufacturer, drug manufacturer name, device trade name]

11. neutropeni\$.mp. [mp=title, abstract, subject headings, drug trade name, original title, device manufacturer, drug manufacturer name, device trade name]

12. carcino\$.mp. [mp=title, abstract, subject headings, drug trade name, original title, device manufacturer, drug manufacturer name, device trade name]

13. adenocarcinoma\$.mp. [mp=title, abstract, subject headings, drug trade name, original title, device manufacturer, drug manufacturer name, device trade name]

14. lymphoma\$.mp. [mp=title, abstract, subject headings, drug trade name, original title, device manufacturer, drug manufacturer name, device trade name]

15. (radioth\$ or radiat\$ or irradiat\$).mp. [mp=title, abstract, subject headings, drug trade name, original title, device manufacturer, drug manufacturer name, device trade name]

16. (bone adj marrow adj5 transplant\$).mp. [mp=title, abstract, subject headings, drug trade name, original title, device manufacturer, drug manufacturer name, device trade name]

17. chemo\$.mp. [mp=title, abstract, subject headings, drug trade name, original title, device manufacturer, drug manufacturer name, device trade name]

18. or/1-17

19. exp STOMATITIS/

20. Candidiasis, Oral/ 
21. stomatitis.mp. [mp=title, abstract, subject headings, drug trade name, original title, device manufacturer, drug manufacturer name, device trade name]

22. mucositis.mp. [mp=title, abstract, subject headings, drug trade name, original title, device manufacturer, drug manufacturer name, device trade name]

23. (oral and cand\$).mp. [mp=title, abstract, subject headings, drug trade name, original title, device manufacturer, drug manufacturer name, device trade name]

24. (oral adj6 mucos\$).mp. [mp=title, abstract, subject headings, drug trade name, original title, device manufacturer, drug manufacturer name, device trade name]

25. (oral and fung\$).mp. [mp=title, abstract, subject headings, drug trade name, original title, device manufacturer, drug manufacturer name, device trade name]

26. (mycosis or mycotic).mp. [mp=title, abstract, subject headings, drug trade name, original title, device manufacturer, drug manufacturer name, device trade name]

27. or/19-26

28. 18 and 27

\section{Cochrane / OHG Search filter for MEDLINE via OVID}

Cochrane Highly Sensitive Search Strategy (CHSSS) for identifying randomized trials in MEDLINE: sensitivity maximising version (September 2008 revision) as referenced in Chapter 6 and detailed in box 6.4.c of The Cochrane Handbook for Systematic Reviews of Interventions Version 5.0.1 [updated September 2008].

1. randomized controlled trial.pt.

2. controlled clinical trial.pt.

3. randomized.ab.

4. placebo.ab.

5. drug therapy.fs.

6. randomly.ab.

7. trial.ab.

8. groups.ab.

9. or/1-8

10. animals.sh. not (humans.sh. and animals.sh.)

11.9 not 10

\section{Appendix 4. EMBASE SS via OVID search strategy}

1. $\exp$ NEOPLASM/

2. $\exp$ LEUKEMIA/

3. $\operatorname{exp~LYMPHOMA/~}$

4. $\exp$ RADIOTHERAPY/

5. exp bone marrow transplantation/

6. (neoplasm\$ or cancer\$ or leukemi\$ or leukaemi\$ or tumour\$ or tumor\$ or malignan\$ or neutropeni\$ or carcino\$ or adenocarcinoma\$ or lymphoma\$).mp. [mp=title, abstract, subject headings, drug trade name, original title, device manufacturer, drug manufacturer name] 7. (radioth\$ or radiat\$ or irradiat\$ or radiochemo\$).mp. [mp=title, abstract, subject headings, drug trade name, original title, device manufacturer, drug manufacturer name]

8. (bone marrow adj3 transplant\$).mp. [mp=title, abstract, subject headings, drug trade name, original title, device manufacturer, drug manufacturer name]

9. chemo\$.mp. [mp=title, abstract, subject headings, drug trade name, original title, device manufacturer, drug manufacturer name]

10. or/1-9

11. exp Stomatitis/

12. Thrush/

13. (stomatitis or mucositis or (oral and candid\$) or (oral adj4 mucositis) or (oral and fung\$) or mycosis or mycotic or thrush).mp. [mp=title, abstract, subject headings, drug trade name, original title, device manufacturer, drug manufacturer name] 
14. or/11-13

15. 10 and 14

\section{Filter for EMBASE via OVID}

1. random $\$ . t i, a b$.

2. factorial\$.ti,ab.

3. (crossover\$ or cross over\$ or cross-over\$).ti,ab.

4. placebo\$.ti,ab.

5. (doubl\$ adj blind\$).ti,ab.

6. (singl\$ adj blind\$).ti,ab.

7. assign\$.ti,ab.

8. allocat\$.ti,ab.

9. volunteer\$.ti,ab.

10. CROSSOVER PROCEDURE.sh.

11. DOUBLE-BLIND PROCEDURE.sh.

12. RANDOMIZED CONTROLLED TRIAL.sh.

13. SINGLE BLIND PROCEDURE.sh.

14. or/1-13

15. ANIMAL/ or NONHUMAN/ or ANIMAL EXPERIMENT/

16. HUMAN/

17. 16 and 15

18. 15 not 17

19. 14 not 18

\section{Appendix 5. CINAHL via EBSCO search strategy}

S1 (MH "Neoplasms+")

S2 (MH "Leukemia+")

S3 (MH "Lymphoma+")

S4 (MH "Radiotherapy+")

S5 (MH "Bone Marrow Transplantation")

S6 neoplasm*

S7 cancer $^{\star}$

S8 (leukemi ${ }^{\star}$ or leukaemi $\left.{ }^{\star}\right)$

S9 (tumour ${ }^{\star}$ or tumor ${ }^{\star}$ )

S10 malignan*

S11 neutropeni*

S12 carcino*

S13 adenocarcinoma*

S14 lymphoma*

S15 (radioth $^{\star}$ or radiat $^{\star}$ or irradiat ${ }^{\star}$ )

S16 (bone N1 marrow N5 transplant ${ }^{\star}$ )

S17 chemo*

$\mathrm{S} 18 \mathrm{~S} 1$ or $\mathrm{S} 2$ or $\mathrm{S} 3$ or $\mathrm{S} 4$ or $\mathrm{S} 5$ or $\mathrm{S} 6$ or $\mathrm{S} 7$ or $\mathrm{S} 8$ or $\mathrm{S} 9$ or $\mathrm{S} 10$ or $\mathrm{S} 11$ or 
$\mathrm{S} 12$ or $\mathrm{S} 13$ or $\mathrm{S} 14$ or $\mathrm{S} 15$ or $\mathrm{S} 16$ or $\mathrm{S} 17$

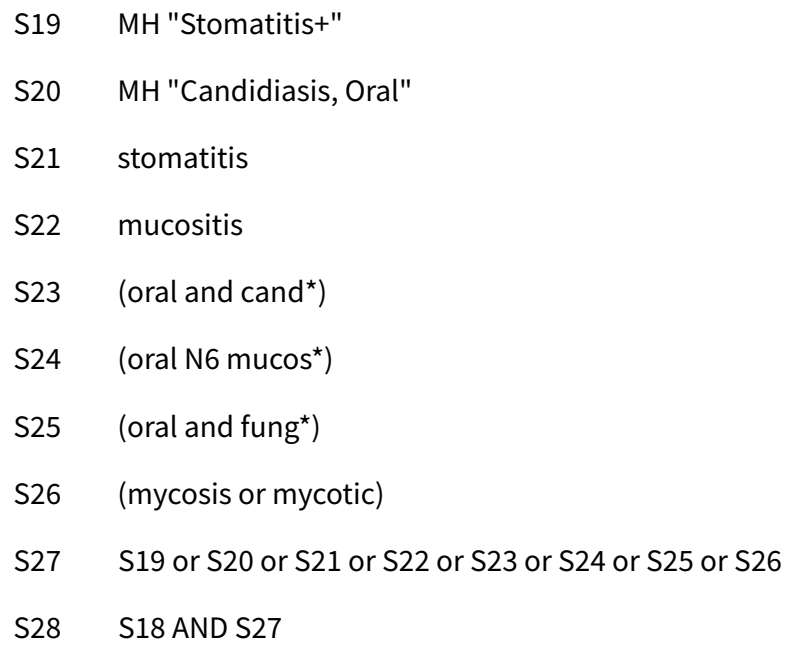

Filter for use with CINAHL search:

S1 MH Random Assignment or MH Single-blind Studies or MH Double-blind Studies or MH Triple-blind Studies or MH Crossover design or MH Factorial Design

S2 TI ("multicentre study" or "multicenter study" or "multi-centre study" or "multi-center study") or AB ("multicentre study" or "multicenter study" or "multi-centre study" or "multi-center study") or SU ("multicentre study" or "multicenter study" or "multi-centre study" or "multi-center study")

S3 TI random* or $\mathrm{AB}$ random*

S4 AB "latin square" or TI "latin square"

S5 TI (crossover or cross-over) or AB (crossover or cross-over) or SU (crossover or cross-over)

S6 MH Placebos

S7 $\quad \mathrm{AB}\left(\right.$ singl $^{\star}$ or doubl ${ }^{\star}$ or trebl ${ }^{\star}$ or tripl $\left.l^{\star}\right)$ or TI $\left(\operatorname{sing} l^{\star}\right.$ or doubl $^{\star}$ or trebl $l^{\star}$ or tripl $\left.l^{\star}\right)$

S8 TI blind* or AB mask ${ }^{*}$ or AB blind ${ }^{*}$ or TI mask*

S9 $\quad$ S7 and S8

S10 TI Placebo* or AB Placebo* or SU Placebo*

S11 MH Clinical Trials

S12 TI (Clinical AND Trial) or AB (Clinical AND Trial) or SU (Clinical AND Trial)

$\mathrm{S} 13 \mathrm{~S} 1$ or $\mathrm{S} 2$ or $\mathrm{S} 3$ or $\mathrm{S} 4$ or $\mathrm{S} 5$ or $\mathrm{S} 6$ or $\mathrm{S} 9$ or $\mathrm{S} 10$ or $\mathrm{S} 11$ or $\mathrm{S} 12$

\section{Appendix 6. CANCERLIT (PubMed Cancer Subset) search strategy}

((neoplasm* OR leukemia OR leukaemia OR leukaemia OR lymphoma* OR plasmacytoma OR "histiocytosis malignant" OR reticuloendotheliosis OR "sarcoma mast cell" OR "Letterer Siwe disease" OR "immunoproliferative small intestine disease" OR "Hodgkin disease" OR "histiocytosis malignant" OR "bone marrow transplant" OR cancer* Or tumor* OR tumour* OR malignan* OR neutropeni* OR carcino* OR adenocarcinoma* OR radioth* OR radiat* OR radiochemo* OR irradiat* OR chemotherap*) AND (stomatitis OR "Stevens Johnson syndrome" OR "candidiasis oral" OR mucositis OR (oral AND (candid* OR mucos* OR fung*)) OR mycosis OR mycotic OR thrush))

AND 
(randomized controlled trial [pt] OR controlled clinical trial [pt] OR randomized controlled trials [mh] OR random allocation [mh] OR double-blind method [mh] OR single-blind method [mh] OR clinical trial [pt] OR clinical trials [mh] OR ("clinical trial" [tw] OR ((singl* [tw] OR doubl* [tw] OR trebl* [tw] OR tripl* [tw]) AND (mask* [tw] OR blind* [tw] )) OR (placebos [mh] OR placebo* [tw] OR random* [tw] OR research design [mh:noexp]) NOT (animals [mh] NOT human [mh]))

\section{Appendix 7. SIGLE search strategy}

\section{N.B. SIGLE is now provided through OpenSIGLE: http://opensigle.inist.fr/}

SIGLE no longer supports complex searching, so a series of keyword searches was performed as below:

cancer AND mucositis AND oral

leukemia AND mucositis AND oral

leukaemia AND mucositis AND oral

carcinoma AND mucositis AND oral

lymphoma AND mucositis AND oral

tumour AND mucositis AND oral

tumor AND mucositis AND oral

cancer AND candidiasis AND oral

leukemia AND candidiasis AND oral

leukaemia AND candidiasis AND oral

carcinoma AND candidiasis AND oral

lymphoma AND candidiasis AND oral

tumour AND candidiasis AND oral

tumor AND candidiasis AND oral

\section{Appendix 8. LILACS search strategy}

(www.bireme.org)

((Pt randomized controlled trial OR Pt controlled clinical trial OR Mh randomized controlled trials OR Mh random allocation OR Mh double-blind method OR Mh single-blind method) AND NOT (Ct animals AND NOT (Ct human and Ct animal)) OR (Pt clinical trial OR Ex E05.318.760.535\$ OR (Tw clin\$ AND (Tw trial\$ OR Tw ensa\$ OR Tw estud\$ OR Tw experim\$ OR Tw investiga\$)) OR ((Tw singl\$ OR Tw simple \$ OR Tw doubl\$ OR Tw doble\$ OR Tw duplo\$ OR Tw trebl\$ OR Tw trip\$) AND (Tw blind\$ OR Tw cego\$ OR Tw ciego\$ OR Tw mask\$ OR Tw mascar\$)) OR Mh placebos OR Tw placebo\$ OR (Tw random\$ OR Tw randon\$ OR Tw casual\$ OR Tw acaso\$ OR Tw azar OR Tw aleator\$) OR Mh research design) AND NOT (Ct animals AND NOT (Ct human and Ct animals)) OR (Ct comparative study OR Ex E05.337\$ OR Mh followup studies OR Mh prospective studies OR Tw control\$ OR Tw prospectiv\$ OR Tw volunt\$ OR Tw volunteer\$) AND NOT (Ct animals AND NOT (Ct human and Ct animals)))

AND

Mh NEOPLASMS OR Tw neoplasm\$ OR Tw cancer\$ OR Tw carcinoma\$ OR Tw tumour\$ OR Tw tumor\$ OR Tw malignan\$ OR Tw carcino\$ OR Tw nuetropeni\$ OR Tw adenocarcinoma\$ OR Mh leukemia OR Tw leukaemia\$ OR Tw leukemi\$ OR Tw lymphoma\$ OR Tw "bone marrow transplantation" OR Tw "bone marrow transplant\$" OR Tw radiotherapy OR Tw radioth\$ OR Tw radiat\$ OR Tw irradiat\$ OR Tw radiochemo \$OR Tw chemo\$

AND

Mh stomatitis OR Tw stomatitis OR Mh Candidiasis-Oral OR Tw "oral candidiasis" OR (Tw candida\$ AND (Tw mouth OR Tw oral)) OR Tw mucositis OR ((Tw oral OR mouth) AND Tw fung\$) OR (Tw oral AND Tw candidiasis\$) 
WHAT'S NEW

\begin{tabular}{lll}
\hline Date & Event & Description \\
\hline 16 September 2019 & Review declared as stable & $\begin{array}{l}\text { This review is not a priority for updating as the question has } \\
\text { been adequately answered - antifungal drugs absorbed or par- } \\
\text { tially absorbed from the GI tract prevent oral candidiasis in peo- } \\
\text { ple receiving treatment for cancer. }\end{array}$ \\
& & \\
\hline
\end{tabular}

\section{H I S T O R Y}

Protocol first published: Issue 1, 1998

Review first published: Issue 1, 2000

\begin{tabular}{lll}
\hline Date & Event & Description \\
\hline 5 August 2009 & New search has been performed & $\begin{array}{l}\text { Search re-run and 2 studies identified which have been added } \\
\text { as pending. Neither study will change the results or conclusions } \\
\text { of the review. In one study Elad 2006 - no patients got candidia- } \\
\text { sis. Corvo 2008 fluconazole is compared to placebo, showing a } \\
\text { reduction in candidiasis. This will not change the conclusions of } \\
\text { the review. One excluded study Vehreschild 2007 added. }\end{array}$ \\
\hline 7 November 2006 & New citation required but conclusions & $\begin{array}{l}\text { With this update we found no new included trials but new ex- } \\
\text { cluded studies. This makes no difference to the results or to the } \\
\text { conclusions. }\end{array}$ \\
\hline
\end{tabular}

\section{CONTRIBUTIONS OF AUTHORS}

Jan Clarkson (JC) and Helen Worthington (HW) wrote the protocol and review. HW co-ordinated the review and wrote the letters to authors. $\mathrm{HW}$ and JC independently and in duplicate assessed the eligibility of trials, extracted data and assessed the quality of the trials. Tim Eden provided advice on cancer, its treatment and the interventions included in the review and checked the data. HW conducted the statistical analysis.

\section{DECLARATIONS OF INTEREST}

None known.

\section{SOURCES OF SUPPORT}

\section{Internal sources}

- University of Manchester, UK.

- NHS Education for Scotland, UK.

- Dental Health Services Research Unit, University of Dundee, UK.

\section{External sources}

- NIDCR grant ref 1 DE016950-01, USA.

\section{N O T E S}

This review will not be updated as the question has been adequately answered - antifungal drugs absorbed or partially absorbed from the $\mathrm{GI}$ tract prevent oral candidiasis in people receiving treatment for cancer. 


\section{N D EX TERMS}

\section{Medical Subject Headings (MeSH)}

Antifungal Agents [pharmacokinetics] [^therapeutic use]; Candidiasis, Oral [*prevention \& control]; Intestinal Absorption; Neoplasms $\left[{ }^{\star}\right.$ drug therapy] [ ${ }^{\star}$ radiotherapy]; Randomized Controlled Trials as Topic

\section{MeSH check words}

Humans 